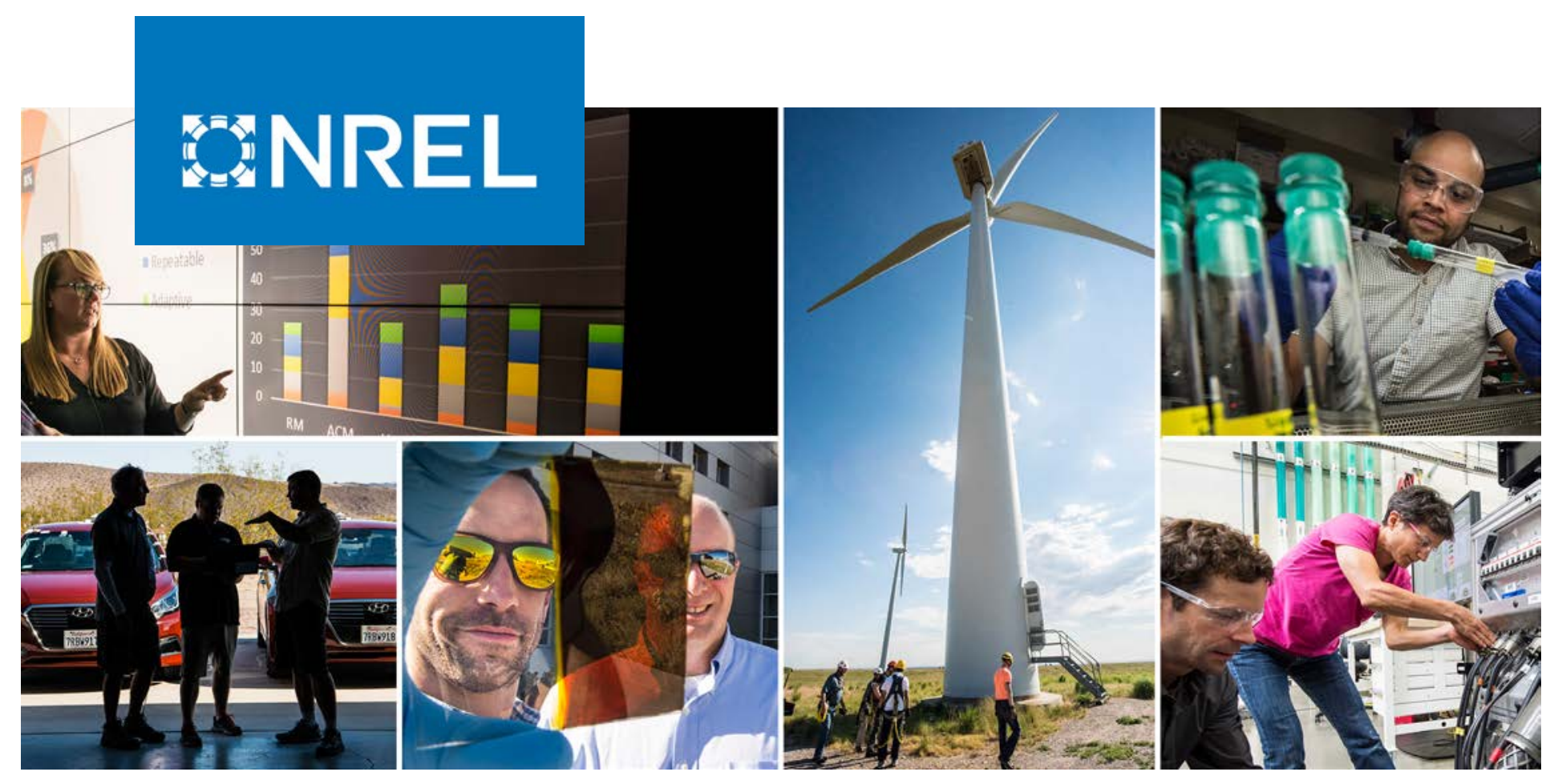

\title{
Basin-Wide Approaches to Hydropower Relicensing: Case Studies and Considerations
}

Taylor L. Curtis and Heather Buchanan

National Renewable Energy Laboratory

NREL is a national laboratory of the U.S. Department of Energy

Office of Energy Efficiency \& Renewable Energy

Operated by the Alliance for Sustainable Energy, LLC

This report is available at no cost from the National Renewable Energy Laboratory (NREL) at www.nrel.gov/publications.

\section{Technical Report}

NREL/TP-6A20-71979

January 2019 


\section{GNREL}

\section{Basin-Wide Approaches to Hydropower Relicensing: Case Studies and Considerations}

\section{Taylor L. Curtis and Heather Buchanan}

National Renewable Energy Laboratory

\section{Suggested Citation}

Curtis, Taylor L. and Heather Buchanan. 2019. Basin-Wide Approaches to Hydropower Relicensing: Case Studies and Considerations. Golden, CO: National Renewable Energy Laboratory. NREL/TP-6A20-71979. https://www.nrel.gov/docs/fy19osti/71979.pdf.

NREL is a national laboratory of the U.S. Department of Energy Office of Energy Efficiency \& Renewable Energy Operated by the Alliance for Sustainable Energy, LLC

This report is available at no cost from the National Renewable Energy Laboratory (NREL) at www.nrel.gov/publications.

Contract No. DE-AC36-08GO28308
Technical Report

NREL/TP-6A20-71979

January 2019

National Renewable Energy Laboratory 15013 Denver West Parkway Golden, CO 80401 303-275-3000 • www.nrel.gov 


\section{NOTICE}

This work was authored by the National Renewable Energy Laboratory, operated by Alliance for Sustainable Energy, LLC, for the U.S. Department of Energy (DOE) under Contract No. DE-AC36-08G028308. Funding provided by the U.S. Department of Energy Office of Energy Efficiency and Renewable Energy Water Power Technologies Office. The views expressed herein do not necessarily represent the views of the DOE or the U.S. Government.

This report is available at no cost from the National Renewable Energy Laboratory (NREL) at www.nrel.gov/publications.

U.S. Department of Energy (DOE) reports produced after 1991 and a growing number of pre-1991 documents are available free via www. OSTI.gov.

Cover Photos by Dennis Schroeder: (clockwise, left to right) NREL 51934, NREL 45897, NREL 42160, NREL 45891, NREL 48097, NREL 46526.

NREL prints on paper that contains recycled content. 


\section{Acknowledgments}

The authors gratefully acknowledge the U.S. Department of Energy, Office of Energy Efficiency and Renewable Energy, Water Power Technologies Office for its funding support. We also thank the following reviewers for their time and expertise: Corey Vezina and Tim Welch, U.S.

Department of Energy, and Jaquelin Cochran, Aaron Levine, Dan Bilello, and Mary Lukkonen (editor), National Renewable Energy Laboratory.

We thank the following contributors for their time and expertise: Jessica Hart, Christopher Hogan, and Jonathan Binder, New York State Department of Environmental Conservation; John Wiley, U.S. Fish and Wildlife Service; David Fox, Cube Hydro Partners, LLC.; Sayad Moudachirou, Ampersand Energy Partners, LLC; Steven Murphy, Brookfield Renewable Partners; Cheryl Laatsch, Wisconsin Department of Natural Resources; Jeff Crocker, Vermont Department of Conservation; James Duggan, Laura Trieschmann, and Yvonne Basque, Vermont Agency of Commerce and Community Development; Ann Marie Ore and Jeff Wetzel, California State Water Resources Control Board; Kathy Howatt, Maine Department of Environmental Protection; Loren Moore and Barry Burnell, Idaho Department of Environmental Quality; Mark Cecchini-Beaver, Office of Idaho Attorney General; Jan Lee, Northwest Hydropower Association; Kevin Lewis, Idaho Rivers United; Melanie Harris, NOAA Fisheries; Kelly Catlett, Hydropower Reform Coalition; Mark Oakley and Jeff Lineberger, Duke Energy; and Jack Wadleigh, National Renewable Energy Laboratory. 


\section{List of Acronyms}

$\begin{array}{ll}\text { AIR } & \text { additional information request } \\ \text { ALP } & \text { Alternative Licensing Process } \\ \text { CEQA } & \text { California Environmental Quality Act } \\ \text { CWA } & \text { Clean Water Act } \\ \text { CZMA } & \text { Coastal Zone Management Act } \\ \text { DOE } & \text { U.S. Department of Energy } \\ \text { EA } & \text { Environmental Assessment } \\ \text { ECPA } & \text { Electric Consumers Protection Act } \\ \text { EIS } & \text { Environmental Impact Statement } \\ \text { ESA } & \text { Endangered Species Act } \\ \text { FERC } & \text { Federal Energy Regulatory Commission } \\ \text { FPA } & \text { Federal Power Act } \\ \text { FPC } & \text { Federal Power Commission } \\ \text { FWCA } & \text { Fish and Wildlife Coordination Act } \\ \text { GW } & \text { gigawatt } \\ \text { HUC } & \text { hydrologic unit code } \\ \text { IDEQ } & \text { Idaho Department of Environmental Quality } \\ \text { kW } & \text { kilowatt } \\ \text { MDEP } & \text { Maine Department of Environmental Protection } \\ \text { MW } & \text { megawatt } \\ \text { NEPA } & \text { National Environmental Policy Act } \\ \text { NH DES } & \text { New Hampshire Department of Environmental Services } \\ \text { NHPA } & \text { National Historic Preservation Act } \\ \text { NOAA } & \text { National Oceanic and Atmospheric Administration } \\ \text { NOI } & \text { notice of intent } \\ \text { NREL } & \text { National Renewable Energy Laboratory } \\ \text { NYSDEC } & \text { New York State Department of Environmental Conservation } \\ \text { ODEQ } & \text { Oregon Department of Environmental Quality } \\ \text { ORNL } & \text { Oak Ridge National Laboratory } \\ \text { PAD } & \text { pre-application document } \\ \text { REA } & \text { ready for environmental analysis } \\ \text { SCE } & \text { Southern California Edison } \\ \text { SWRCB } & \text { California State Water Resources Control Board } \\ \text { TMDL } & \text { total maximum daily load } \\ \text { TVA } & \text { Tennessee Valley Authority } \\ \text { USFWS } & \text { U.S. Fish and Wildlife Service } \\ \text { VT DEC } & \text { Vermont Department of Environmental Conservation } \\ \text { WDNR } & \text { Wisconsin Department of Natural Resources } \\ \text { WPL } & \text { Wisconsin Power and Light Co. } \\ \text { WPSC } & \text { Wisconsin Public Service Corporation } \\ \text { WSRA } & \text { Wild and Scenic Rivers Act } \\ & \\ \text { NEA } & \end{array}$




\section{Executive Summary}

In the United States there are 1,043 active Federal Energy Regulatory Commission (FERC) licensed hydroelectric projects with a total capacity of 56,097 MW. Of those FERC-licensed hydropower projects, 647 with a total capacity of 21,870 MW have license expiration dates from 2018-2037. FERC anticipates receiving a total of 1,012 hydropower filings for relicense (i.e., a new operating license for an existing facility) through September 2032. Of those total filings, 551 are expected to be notices of intent for a new license and 461 are expected to be applications for a new license.

The expected workload in conjunction with the time, cost, and complexity associated with issuing a single new license has led to initiatives that aim to increase the efficiency of the relicensing process. Federal and state regulators and licensees in states such as California, Maine, New York, and Wisconsin have begun to develop approaches to look at hydropower relicensing as part of a larger system - a river basin. Recognizing the number of hydropower projects within a shared waterway, these basin-wide approaches seek to coordinate different stages of the relicensing process for multiple projects at the same time.

Although these basin-wide approaches focus on different aspects of the relicensing process and involve varying degrees of coordination and collaboration, the overall intent is the same. The goal is that these initiatives increase the efficiency of the relicensing process and allow for a more comprehensive analysis of the cumulative impacts of the projects within the basin. These innovative approaches to relicensing could also reduce the workload for regulators and costs associated with relicensing. To that end, finding regulatory efficiencies and cost savings within the relicensing process will help ensure hydropower's contributions toward meeting the nation's energy needs, maintaining national infrastructure, and improving national security. 


\section{Table of Contents}

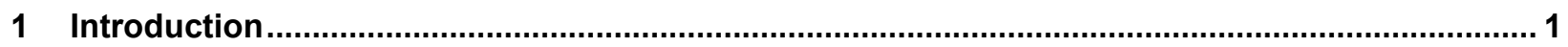

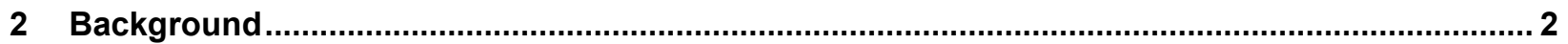

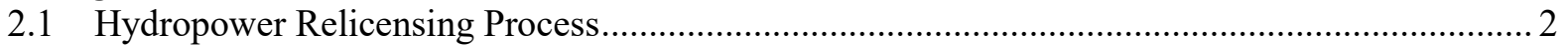

2.1.1 Electric Consumers Protection Act of 1986 Amendments to the Federal Power Act...... 2

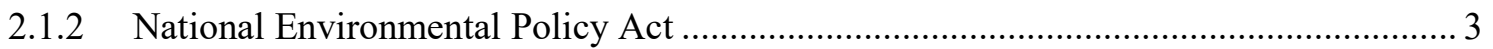

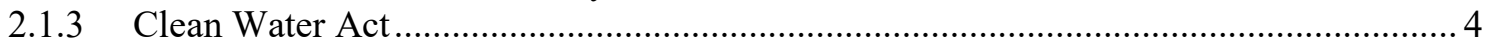

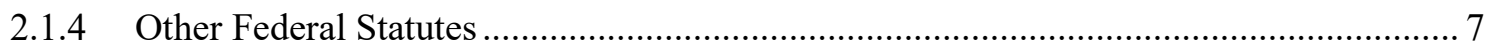

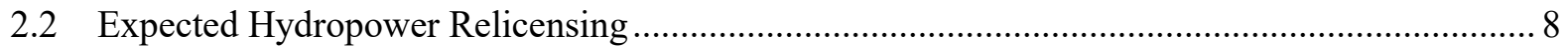

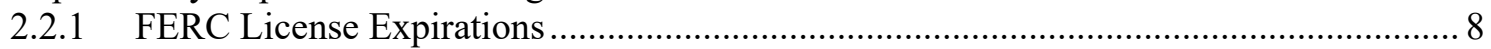

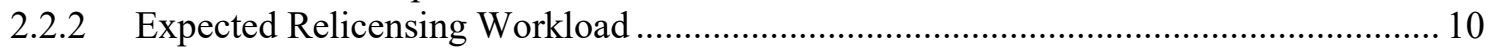

2.2.3 Projects in a Shared River Basin or Sub-Basin ............................................................ 11

3 Coordinating FERC License Terms for Hydropower Projects Within a Shared River Basin ..... 13

3.1 Accelerating or Extending License Terms ........................................................................ 13

3.1.1 Non-Default FERC License Term Example ............................................................ 14

3.1.2 FERC License Term Extension Examples .................................................................... 14

3.1.3 FERC License Term Acceleration Example .............................................................. 15

3.1.4 FERC License Term Acceleration and Extension Example........................................... 15

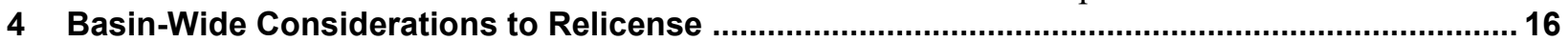

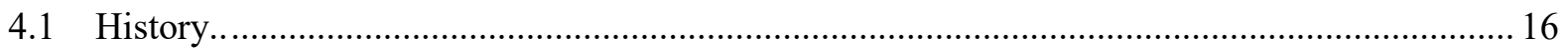

4.2 Comprehensive Basin-Wide Approaches to Relicense ............................................................... 17

4.2.1 New York Black River Basin-Wide Relicensing Pilot................................................ 17

4.2.2 Wisconsin River Basin-Wide Relicensing Proposal ..................................................... 27

4.2.3 General Advantages and Challenges of Comprehensive Basin-wide Approaches to

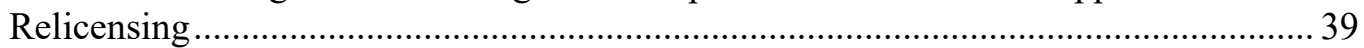

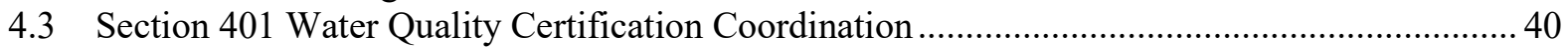

4.3.1 California Big Creek Basin-Wide Pilot..................................................................... 41

4.4 Projects Within a River Basin that Cross Multiple Jurisdictions ......................................... 47

4.4.1 Hells Canyon Hydroelectric Complex ........................................................................ 47

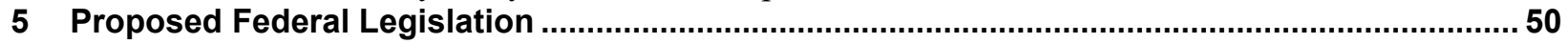

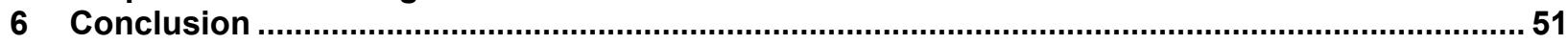

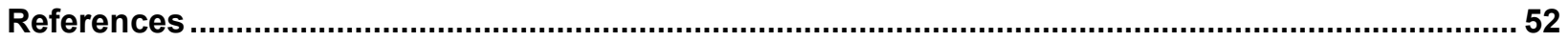

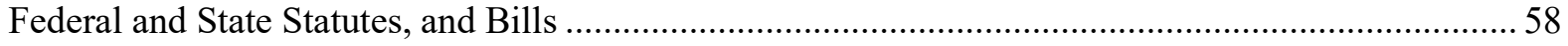

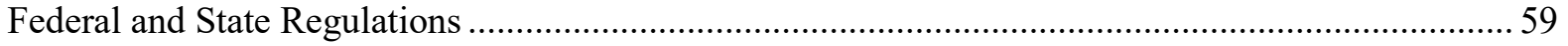

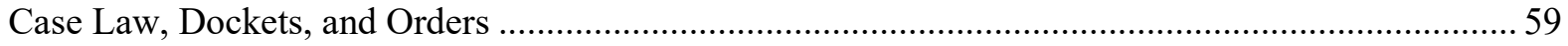

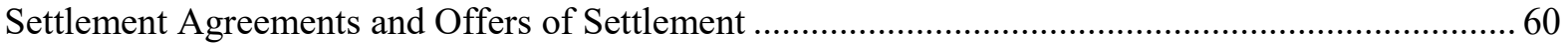




\section{List of Figures}

Figure 1. FERC-licensed projects with license expiration dates from 2018-2037 ................................ 9

Figure 2. Top 10 states by number of projects-FERC-licensed projects with license expiration dates

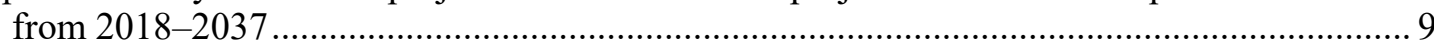

Figure 3. Top 10 states by authorized capacity_FERC-licensed projects with license expiration dates

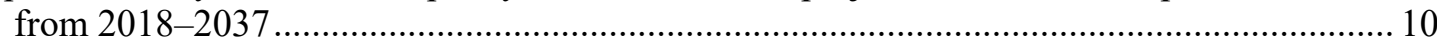

Figure 4. Expected FERC relicensing filings from 2018-2032 ................................................... 11

Figure 5. FERC-licensed projects with license expiration dates from 2018-2037 within a shared river

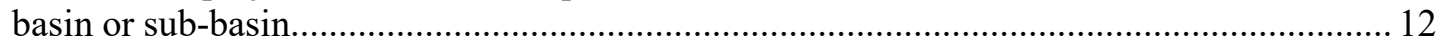

Figure 6. Black River Basin hydropower relicensing workload—projects and developments.................. 18

Figure 7. Black River Basin pilot: map of hydropower projects ......................................................... 19

Figure 8. Black River Basin pilot: Basin-wide relicensing timeline ..................................................... 21

Figure 9. Wisconsin River Basin hydropower relicensing workload-projects and developments ........... 28

Figure 10. Wisconsin River Basin proposal: map of hydropower projects ............................................ 32

Figure 11. Big Creek case study: map of hydropower projects ............................................................ 42

\section{List of Tables}

Table 1. Relicensing Projects Delayed by Pending Water Quality Certifications ...................................... 7

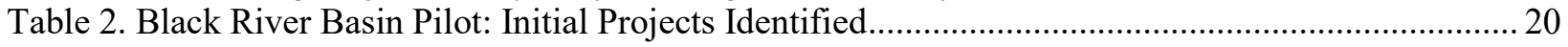

Table 3. Black River Basin Pilot: Project Characteristics..................................................................... 25

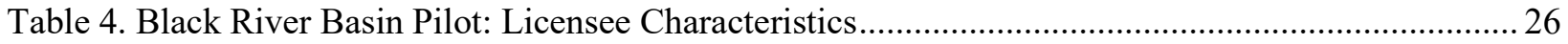

Table 5. Wisconsin River Basin Proposal: Projects ............................................................................. 30

Table 6. Wisconsin River Basin Proposal: License Expiration Date Alignment ...................................... 34

Table 7. Wisconsin River Basin Proposal: Project Characteristics......................................................... 35

Table 8. Wisconsin River Basin Proposal: Licensee Characteristics......................................................... 37

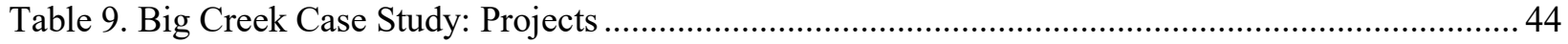




\section{Introduction}

In the United States there are 1,043 active Federal Energy Regulatory Commission (FERC) licensed hydroelectric projects with a total capacity of 56,097 MW (FERC 2018a). Of those FERC-licensed hydropower projects, 647 with a total capacity of 21,870 MW have license expiration dates from 2018-2037 (FERC 2017a).

FERC anticipates receiving a total of 1,012 hydropower filings for relicense (i.e., a new operating license for an existing facility) through September 2032. Of those total filings, 551 are expected to be notices of intent for a new license and 461 are expected to be applications for a new license (FERC 2017a). The relicensing process requires thorough federal, state, and public review. The reviews and compliance requirements associated with the relicensing process often require significant capital investment and are frequently as time and resource intensive as the original licensing process (Uria-Martinez et al. 2018; Levine et al. 2017).

The expected workload in conjunction with the time, cost, and complexity associated with issuing a single new license has led to initiatives that aim to increase the efficiency of the relicensing process. Federal and state regulators and licensees in states such as California, Maine, New York, and Wisconsin have begun to develop approaches to look at hydropower relicensing as part of a larger system - a river basin. Recognizing the number of hydropower projects within a shared waterway, these basin-wide approaches seek to coordinate different stages of the relicensing process for multiple projects at the same time.

In California and Maine, regulators have implemented a basin-wide approach for review and issuance of Clean Water Act (CWA) Section 401 water quality certifications. State regulators may, at the request of the licensee, coordinate the review of multiple separately licensed hydropower projects within a shared river basin and issue a single certification. In New York and Wisconsin, regulators and licensees are working on a more comprehensive basin-wide approach to hydropower relicensing. These comprehensive approaches seek to align the relicensing timelines of multiple separately licensed hydropower facilities located within a shared basin that are owned and operated by different licensees.

Although these basin-wide approaches focus on different aspects of the relicensing process and involve varying degrees of coordination and collaboration, the overall intent is the same. These initiatives seek to increase the efficiency of the relicensing process and allow for a more comprehensive analysis of the cumulative impacts of the projects within the shared basin. These innovative approaches to relicensing could also reduce the workload for regulators and costs associated with relicensing.

This report analyzes basin-wide approaches to the FERC relicensing process for non-federal hydropower projects. Section 2 provides a summary of the major steps in the FERC relicensing process for non-federal hydropower projects and analyzes FERC-licensed projects with license expiration dates from 2018-2037. Section 3 discusses FERC's authority to coordinate license terms for hydropower projects within a shared river basin, including examples of instances FERC has exercised this power. Section 4 provides basin-wide considerations and relicensing case studies. Section 5 provides a summary of proposed federal legislation regarding hydropower relicensing. 


\section{Background}

This section provides a summary of the FERC hydropower relicensing process and analyzes the FERC-licensed hydropower projects with license expiration dates from 2018-2037.

\subsection{Hydropower Relicensing Process}

Obtaining a new license (relicense) from FERC for the continued operation (30 to 50 years) of an existing hydropower facility is often a complex multi-year regulatory process that requires review by federal and state regulators, Indian tribes, and the public. At least 5 years, but not more than 5.5 years, before the license expiration date, a licensee must file a notice of intent (NOI) with FERC stating whether they intend to seek a new license (18 C.F.R. $\S 5.5$ ). At the same time as filing an NOI, the licensee must file a pre-application document (PAD) (18 C.F.R. $\S 5.6)$. The PAD must include existing information about the project facilities, operation, and known or potential impacts on environmental quality, including protection, mitigation, and enhancement measures (18 C.F.R. § 5.6). ${ }^{1}$ The PAD serves as the basis for the study plan, license application, and environmental documents that follow. After filing the PAD, the licensee must develop a study plan and conduct studies to supplement the existing information (18 C.F.R. $\S \S 4.38[\mathrm{c}], 5.15,16.8[\mathrm{c}])$. Typically, studies are undertaken according to the study plan within 33.5 years before applying for a new license.

Consideration: The study plan should include studies that supplement existing information needed to complete the exhibits required in the new license application and the environmental document, including, but not limited to, water flow data and modeling results and impacts on the passage of riverine or diadromous fish; wetlands, riparian, and littoral habitat; rare, threatened, and endangered species; recreation and land use; aesthetic resources; and cultural resources (18 C.F.R. $\S \S 4.32,4.34,4.38,4.41,4.61,5.18,16.8,16.10)$.

At least 2 years before a license expires, the licensee must file an application for a new license (relicense) with FERC (18 C.F.R. $\S 808[\mathrm{c}]$ ). The new license application must include project information and synthesize the study results and consultation requirements describing the project design, operation, and environmental impacts of the project (18 C.F.R. $\S 4.32$ ). Before issuing a new license, FERC assesses the hydropower facility, in accordance with the Federal Power Act (FPA), to ensure the facility represents the best public use of waterway resources (16 U.S.C. $\S$ $797[\mathrm{e}])$.

\subsubsection{Electric Consumers Protection Act of 1986 Amendments to the Federal Power Act}

The Electric Consumers Protection Act of 1986 (ECPA) amended the FPA to require that FERC give "equal consideration" to developmental and non-developmental values when making a public interest determination. Before issuing a license, FERC must consider the power and development issues involved as well as issues related to the project's impact on environmental quality (Abenaki Nation of Mississquoi v. Hughes, 990 F.2d 729 [2d Cir. 1993]). Specifically,

\footnotetext{
${ }^{1}$ The licensee must use due diligence when compiling information for the PAD. "Due diligence" includes contacting appropriate agencies and Indian tribes that may have relevant information and reviewing federal and state comprehensive plans filed with FERC (16 C.F.R. $\S 5.6[\mathrm{~b}][2])$.
} 
FERC must extensively study the project, its surrounding environment, and related resources and give the same level of reflection and thorough evaluation to developmental and nondevelopmental values, including:

- Utilization of the site's hydroelectric potential

- Potential benefits to interstate or foreign commerce

- Adequate protection, mitigation, and enhancement of fish and wildlife (including related spawning grounds and habitat)

- Other beneficial uses, including energy conservation, irrigation, flood control, water supply, recreational opportunities, and other aspects of environmental quality.

(16 U.S.C. $\S 803[a][1] ; 16$ U.S.C. $\S 767[\mathrm{e}]$ )

Consideration: Hydropower projects originally licensed prior to 1986 seeking relicense for the first time should consider the requirements of the FPA, as amended by ECPA.

ECPA amended the FPA to require consultation between the licensee, FERC, and affected federal and state resource agencies (Coggins and Glicksman 2018). In addition:

- $\quad$ ECPA amended Section 10(a) of the FPA which requires FERC to solicit recommendations from resource agencies and Indian tribes on how to make a project more consistent with federal and state comprehensive plans for improving, developing, or conserving a waterway.

- ECPA added Section 10(j) of the FPA, which requires FERC to solicit and consider recommendations from federal and state fish and wildlife agencies regarding the development, operation, and management of the hydropower facility and its impact on fish and wildlife.

\subsubsection{National Environmental Policy Act}

When deciding whether to issue a new license, FERC must comply with the National Environmental Policy Act of 1969 (NEPA). Under NEPA, FERC must prepare and issue an Environmental Assessment (EA) and/or an Environmental Impact Statement (EIS) ${ }^{2}$ that examines alternatives and the likely effects to the human environment from the hydropower facility (40 C.F.R. $\S \S 1501.3$ - 1501.4). FERC typically determines whether an EIS is required by preparing an EA. If, after completing the EA, FERC determines that the new license is likely to have a significant effect on the quality of the human environment, then an EIS is required. If FERC determines that the new license will not have a significant effect on the human environment, then a Finding of No Significant Impact is prepared (40 C.F.R. $\S \S 1501.3,1501.4)$. The requisite environmental document, either an EA or EIS, is an essential part of the relicensing record and forms the basis of FERC's relicensing decision.

\footnotetext{
${ }^{2}$ Compared to an EA, an EIS is a more comprehensive study in which FERC must "rigorously explore and objectively evaluate all reasonable alternatives" for the project (40 C.F.R. $§ 1502.14$ ).
} 
Consideration: The hydropower relicensing process opens the project up to input from multiple stakeholders, including federal, state, and local agencies, non-governmental organizations, and the public (Cumming 2015). Given the extensive evaluation and stakeholder input required, relicensing can have similar timelines and costs to the original licensing process.

FERC initiates the NEPA process by preparing a scoping document for public comment. The scoping document broadly outlines issues to be evaluated in the EA or EIS. Once the licensee files the application for a new license and the studies are complete, FERC issues a ready for environmental analysis (REA) (18 C.F.R. § 5.22). During the REA, state and federal agencies submit mandatory terms and conditions, recommendations, and fishway prescriptions for FERC to adopt or consider as part of the new license (18 C.F.R. $\S 5.23$ ).

\subsubsection{Clean Water Act}

A project going through relicense requires a waiver, revision, or issuance of a state water quality certification. Under Section 401 of the CWA (33 U.S.C. $\S 1251-1376$ [1972]), a federal agency may not issue a license authorizing the construction or operation of a project that "...may result in any discharge into a navigable water..." unless the appropriate state agency first waives or issues a water quality certification (33 U.S.C. $§ 1341[a][1])$. Any limitation included in the state certification becomes a mandatory condition of the FERC license. If the state denies the water quality certification, FERC may not issue a new license (33 U.S.C. $§ 1341[a][1])$.

States have lead responsibility for protecting water quality under the CWA and for administering laws governing allocation of water quantity. The Supreme Court has found that water quality and water quantity are inextricably linked and that both are essential to maintaining the integrity of the nation's waters (Strong 1991; Copeland 2015). In Public Utility District No. 1 of Jefferson County v. Washington Department of Ecology, 511 U.S. 700 (1994), the Supreme Court held that a state acting under the CWA could regulate water quality (e.g., physical and chemical composition of the water) and water quantity (i.e., amount of water released by a project), as well as state-designated water uses (e.g., fishing, boating). The Supreme Court upheld this decision in S.D. Warren Co. v. Maine Board of Environmental Protection, 126 U.S. 1843 (2006). In the 2006 decision, the Supreme Court unanimously held that states, through Section 401 certification, can impose conditions on a FERC hydropower license if they find it necessary to prevent adverse alteration of water quality.

In recent years, many states have come to view Section 401 as an important tool in their overall programs to protect the physical and biological, in addition to the chemical, integrity of their waters (Copeland 2015). Some states use Section 401 to address a wide range of impacts to their water quality, including impacts to aquatic habitat such as wetlands where issues of nonchemical impacts arise (Copeland 2015). Through Section 401, some states have addressed inadequate river flow, inundation of habitat, dissolved oxygen levels, and impacts on fish and other wildlife from a hydropower project (Copeland 2015).

In addition to considering effluent limitations, water quality standards, national standards for new sources, and pretreatment effluent standards, a state agency can impose instream flow requirements on hydropower projects (33 U.S.C. $\S \S 1311-1313,1316-1317$; FERC 2001). State agencies, however, do not have to consider the benefits of hydropower or other competing 
interests when reviewing an application for a water quality certification (FERC 2001). The state does not have to consider whether the conditions of the certificate duplicate or conflict with those imposed by FERC and other agencies (FERC 2001; 33 U.S.C. $\S \S 1251-1376$ [1972]).

\subsubsection{401 Water Quality Certification Workload}

State agencies issue Section 401 water quality certifications not only for hydropower projects seeking a FERC license or relicense but also for dredge-and-fill activities in wetlands and other waters that require approval from the U.S. Army Corps of Engineers under Section 404 of the CWA and Sections 9 and 10 of the Rivers and Harbors Appropriation Act (33 U.S.C. $\S 1344 ; 33$ U.S.C. $\S \S 401-402)$. In addition, state agencies may require certification for other activities that could affect water quality (Public Utility District No. 1 of Jefferson County v. Washington Department of Ecology, 511 U.S. 700 [1994]; S.D. Warren Co. v. Maine Board of Environmental Protection, 126 U.S. 1843 [2006]).

Consideration: States often issue thousands of water quality certifications annually. For instance, the New York State Department of Environmental Conservation issued 5,044 water quality certifications in 2017 (Christopher Hogan, New York State Department of Environmental Conservation, email, September 5, 2018). ${ }^{3}$

In addition to the number of activities ${ }^{4}$ that require a water quality certification, review for certification has grown more complicated in the face of environmental conditions (e.g., drought $)^{5}$ and policy changes affecting water resource demands and water quality (Ann Marie Ore, California Water Resources Control Board, telephone conference, August 2, 2018; Bauer et al. 2015). The growing complexity of certification review in light of these additional resource demands and environmental conditions has led to delay in the certification process in some states (Ann Marie Ore, California Water Resources Control Board, telephone conference, August 2, 2018). State agency budgets and inadequate staffing has, in some cases, exacerbated delay in certification issuances and has led to a backlog in many states (Hawaii State Department of Health 2015; Colorado Legislative Council 2014; Oregon Department of Environmental Quality 2018; Missouri Department of Natural Resources 2008; Ann Marie Ore, California Water Resources Control Board, telephone conference, August 2, 2018; Cheryl Laatsch, Wisconsin Department of Natural Resources, telephone conference, August 7, 2018). There is also evidence that the submission of incomplete applications increases the processing timeline of certifications

\footnotetext{
${ }^{3}$ This number includes all 401 water quality certifications issued, including activities triggered by Sections 404 and 402 of the CWA, Sections 9 and 10 of the Rivers and Harbors Appropriation Act, and other activities designated by the state.

${ }^{4}$ For example, New York State Department of Environmental Conservation has reported that they issued 3,184 water quality certifications in 2016 and 5,044 in 2017 (Christopher Hogan, New York State Department of Environmental Conservation, email, September 5, 2018). Minnesota Pollution Control Agency has reported that they issue 2,000 general 401 water quality certifications annually; this number does not include individual 401 water quality certifications (Minnesota Pollution Control Agency 2018). In 2017 California issued 1,221 Section 401 water quality certifications (Jeff Wetzel, California State Water Resources Board, correspondence, September 19, 2018).

${ }^{5}$ In 2014, 9\% of the State of California experienced exceptional drought and two-thirds of the state was in an extreme drought. Snow pack near Donner Summit in the Sierra Mountains was at 8 inches, the lowest since 1946 (FERC 2014; SWRCB 2014).
} 
and adds to the overall certification backlog (Hawaii State Department of Health 2015; see also Hells Canyon case study).

\subsubsection{401 Water Quality Certification Issuance Timeline}

Despite the 1-year time limit prescribed by the CWA, the review of a Section 401 water quality certification request can often take much longer depending on the state's resources and workload, the complexity of the project, and the water resources affected. A common reason for delay in the hydropower relicensing process is obtaining evidence of a waiver or request for a new or revised state water quality certification (FERC 2001; DOE 2016). Table 1 identifies hydropower projects, as of December 2018, that have been delayed in the relicensing process by pending water quality certifications. 
Table 1. Relicensing Projects Delayed by Pending Water Quality Certifications

\begin{tabular}{|c|c|c|c|c|}
\hline Project & Licensee & State & $\begin{array}{l}\text { Date of NEPA } \\
\text { completion }\end{array}$ & $\begin{array}{l}\text { Delay } \\
\text { (Years) }\end{array}$ \\
\hline Vermillion Valley ${ }^{a}(P-2086)$ & $\begin{array}{l}\text { Southern } \\
\text { California Edison } \\
\text { (SCE) }\end{array}$ & California & $05 / 03 / 2004$ & 14.70 \\
\hline $\begin{array}{l}\text { Upper North Fork Feather } \\
\text { River (P-2105) }\end{array}$ & $\begin{array}{l}\text { Pacific Gas \& } \\
\text { Electric }\end{array}$ & California & $11 / 10 / 2005$ & 13.18 \\
\hline Portal $^{\mathrm{a}}(\mathrm{P}-2174)$ & SCE & California & $04 / 27 / 2006$ & 12.72 \\
\hline Hells Canyon ${ }^{\mathrm{a}}(\mathrm{P}-1971)$ & $\begin{array}{l}\text { Idaho Power } \\
\text { Company }\end{array}$ & Idaho/Oregon & $08 / 31 / 2007$ & 11.37 \\
\hline Big Creek Project 2A $\mathrm{A}^{\mathrm{a}}(\mathrm{P}-7)$ & SCE & California & $03 / 13 / 2009$ & 9.84 \\
\hline $\begin{array}{l}\text { Big Creek Project } 3^{a} \\
(P-120)\end{array}$ & SCE & California & $03 / 13 / 2009$ & 9.84 \\
\hline Mammoth Pool ${ }^{a}(P-2085)$ & SCE & California & 03/13/2009 & 9.84 \\
\hline $\begin{array}{l}\text { Big Creek Project } 1 \& 2 \\
(P-2175)\end{array}$ & SCE & California & 03/12/2009 & 9.84 \\
\hline South Feather (P-2088) & $\begin{array}{l}\text { South Feather } \\
\text { Water \& Power } \\
\text { Agency }\end{array}$ & California & 06/04/2009 & 9.61 \\
\hline McCloud Pit (P-2106) & $\begin{array}{l}\text { Pacific Gas and } \\
\text { Electric }\end{array}$ & California & $02 / 25 / 2011$ & 7.88 \\
\hline Brassua (P-2615) & $\begin{array}{l}\text { Madison Paper } \\
\text { Industries }\end{array}$ & Maine & $09 / 14 / 2011$ & 7.33 \\
\hline 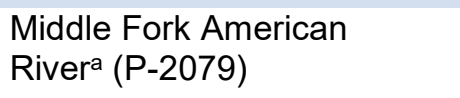 & $\begin{array}{l}\text { Placer County } \\
\text { Water Agency }\end{array}$ & California & $02 / 22 / 2013$ & 5.88 \\
\hline Merced Rivera (P-2179) & $\begin{array}{l}\text { Merced Irrigation } \\
\text { District }\end{array}$ & California & $12 / 04 / 2015$ & 3.10 \\
\hline Merced Falls ${ }^{a}(P-2467)$ & $\begin{array}{l}\text { Merced Irrigation } \\
\text { District }\end{array}$ & California & $12 / 04 / 2015$ & 3.10 \\
\hline Trout Creek (P-848) & $\begin{array}{l}\text { Wells Rural } \\
\text { Electric Company }\end{array}$ & Nevada & $12 / 19 / 2017$ & 1.06 \\
\hline Pine Creek Mine ${ }^{a}(P-12532)$ & $\begin{array}{l}\text { Pine Creek Mine, } \\
\text { LLC }\end{array}$ & California & $02 / 10 / 2018$ & 0.92 \\
\hline Prospect No. 3 (P-2337) & PacifiCorp Energy & Oregon & $04 / 16 / 2018$ & 0.74 \\
\hline
\end{tabular}

a Projects that are also delayed by Section 7 Endangered Species Act review. Source: FERC 2018c

\subsubsection{Other Federal Statutes}

During the relicensing process, the licensee must comply with the FPA, the CWA and other federal statutes, including but not limited to the Fish and Wildlife Coordination Act (FWCA), the 
Endangered Species Act (ESA), the Coastal Zone Management Act (CZMA), and the National Historic Preservation Act (NHPA).

Consideration: "Because the relicensing process...requires a renewed evaluation of the project and its environs, many projects emerge from the relicensing process with different operational, recreational, and environmental [license] conditions..." (Sensiba 2011).

- Section 4(e) of the FPA gives federal land management agencies authority to revise or add new mandatory conditions to hydropower projects located within or directly affecting federal reservations (16 U.S.C. $\S \S 791-823 d$ ).

- Section 18 of the FPA allows federal resource agencies to prescribe mandatory fishway requirements on hydropower projects that may affect the passage of fish species in a project area (16 U.S.C. $\S \S 791-823 d)$.

- The FWCA requires FERC to consult with the U.S. Fish and Wildlife Service (USFWS) and appropriate state and fish wildlife agencies before granting a new license for the control, impoundment, or modification of a waterway (16 U.S.C. $\S \S 661-666 \mathrm{c}$ ).

- The ESA requires FERC to consult with USFWS and NOAA Fisheries to ensure the new license will not jeopardize the continued existence of any endangered species or threatened species or result in the destruction or adverse modification of habitat of such species (16 U.S.C. $\S \S 1531-1544$ ).

- The CZMA requires that federal actions affecting a coastal zone's natural resources be consistent with the state's approved coastal management plan (16 U.S.C. $\S \S 1451-1464)$.

- The NHPA requires FERC to consider the impact of the new license on sites and facilities listed on, or eligible for, the National Register of Historic Places (16 U.S.C. $\S \S$ 1451-1464).

\subsection{Expected Hydropower Relicensing}

This section analyzes FERC-licensed hydropower projects with license expiration dates between 2018-2037, the expected new license (relicense) filing workload through September 2032 and identifies projects within a shared river basin or sub-basin.

\subsubsection{FERC License Expirations}

Of the 1,043 active FERC-licensed hydropower projects, 647 projects with a total combined capacity of 21,870 MW have license expiration dates from 2018-2037 (FERC 2017a; FERC 2018a). Figure 1 illustrates the number of FERC-licensed hydropower projects and authorized capacity due to expire in 5-year periods from 2018-2037. There are 190 projects with license expiration dates from 2023-2027 with a total combined capacity of 7,940 MW. In 2026 alone, 48 project licenses expire (5,058 MW). From 2033-2037, 249 project licenses expire (4,428 MW). The highest volume of expiration dates is in 2034 with 59 projects. 


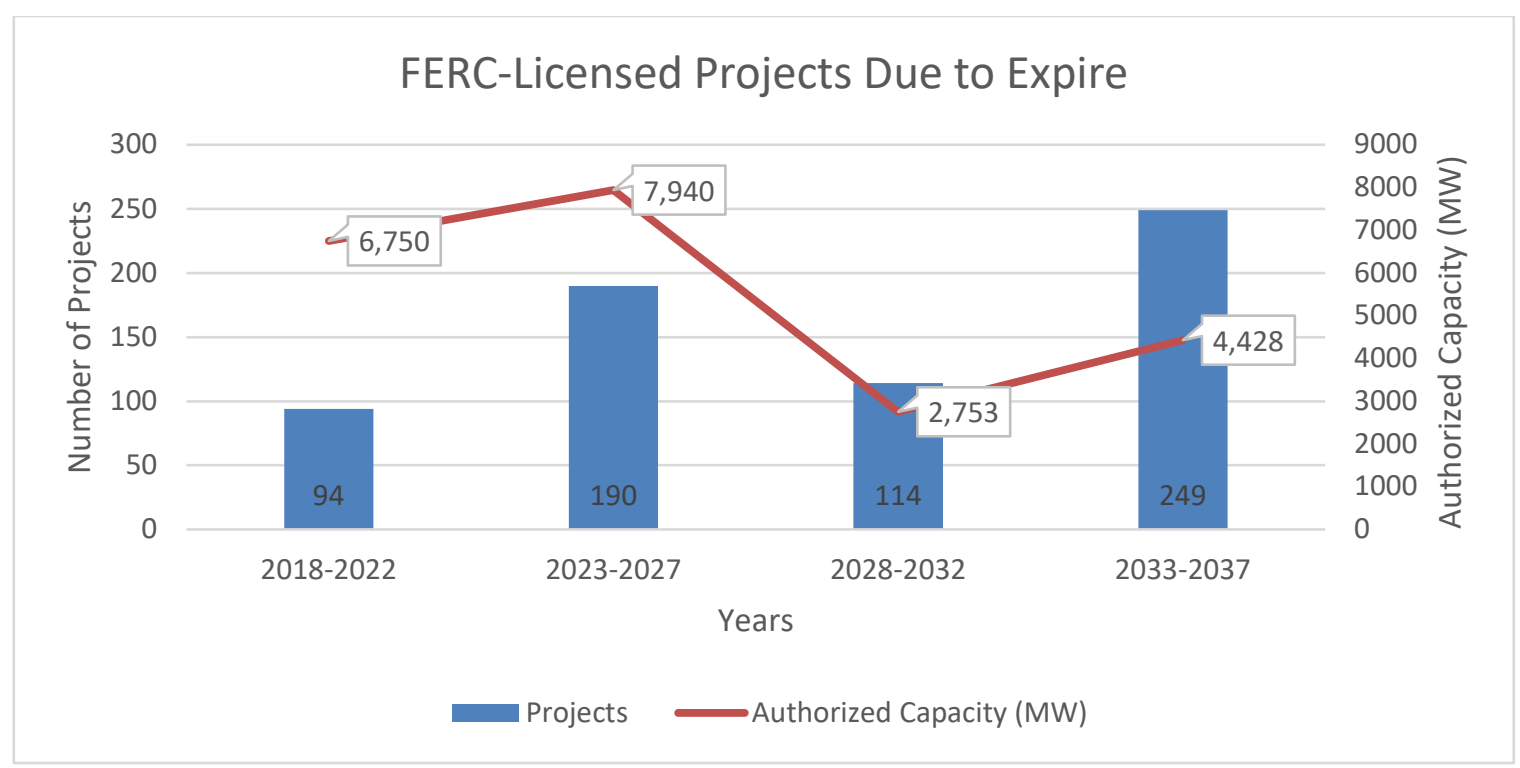

Figure 1. FERC-licensed projects with license expiration dates from 2018-2037

\subsubsection{Top 10 States by Number of Projects}

Figure 2 illustrates the 10 states with the highest number of projects that have FERC licenses due to expire through 2037 (FERC 2017a). The geographic distribution of those projects range across the northeast, midwest, west, and northwest United States. New York has the highest number of FERC-licensed projects expiring with 75 projects with a total combined capacity of approximately 1,834 MW (FERC 2017a).

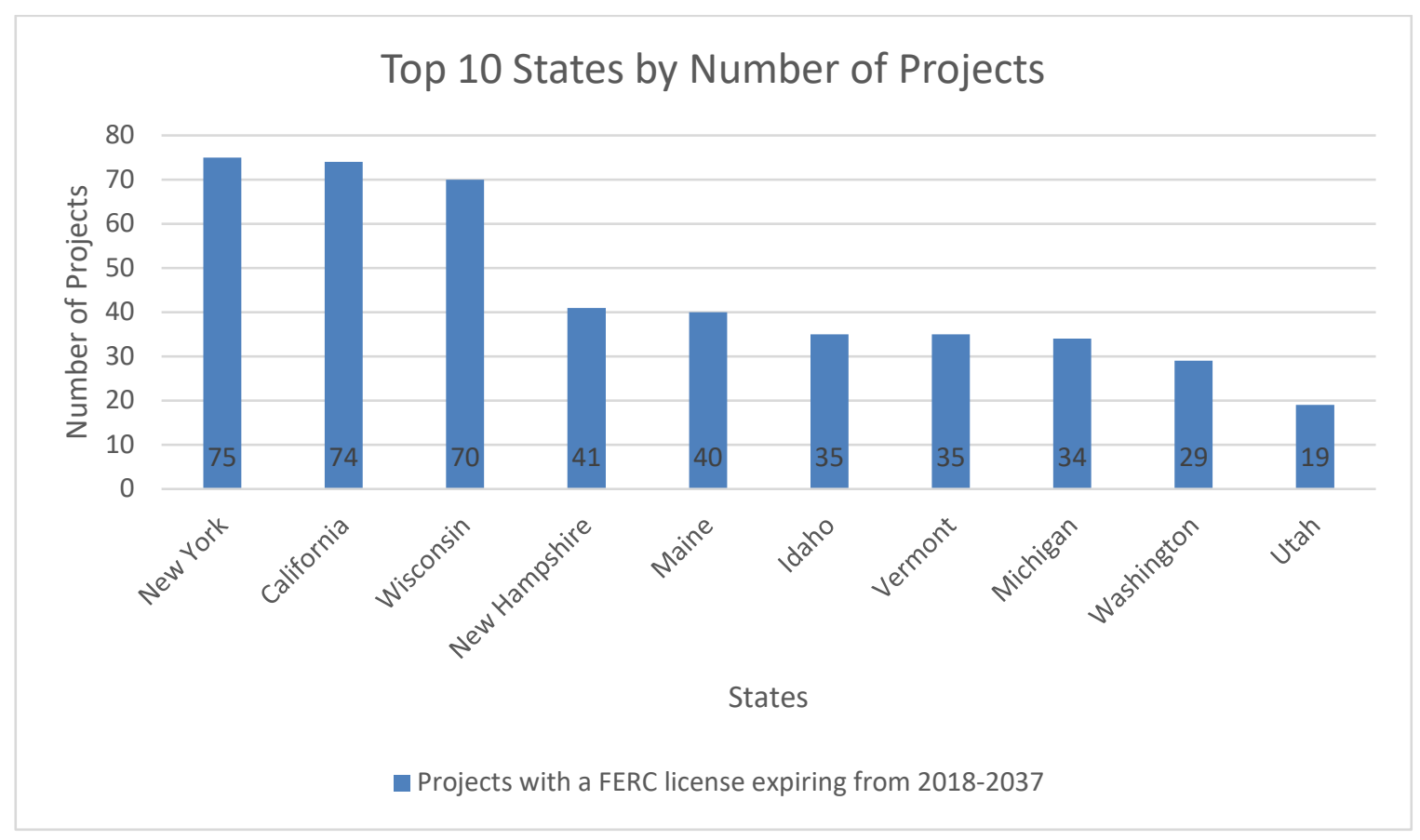

Figure 2. Top 10 states by number of projects-FERC-licensed projects with license expiration dates from 2018-2037 


\subsubsection{Top 10 States by Authorized Capacity}

Figure 3 illustrates the 10 states with the highest number of FERC-licensed projects due to expire through 2037 by authorized hydroelectric capacity. The geographic distribution of states ranges across the northeast, east, southeast, west, and northwest United States. California has the highest total combined capacity of FERC-licensed projects due to expire with 4,387 MW across 74 projects (FERC 2017a). Virginia and South Carolina also have multiple large FERC-licensed projects set to expire in the coming years (FERC 2017a).

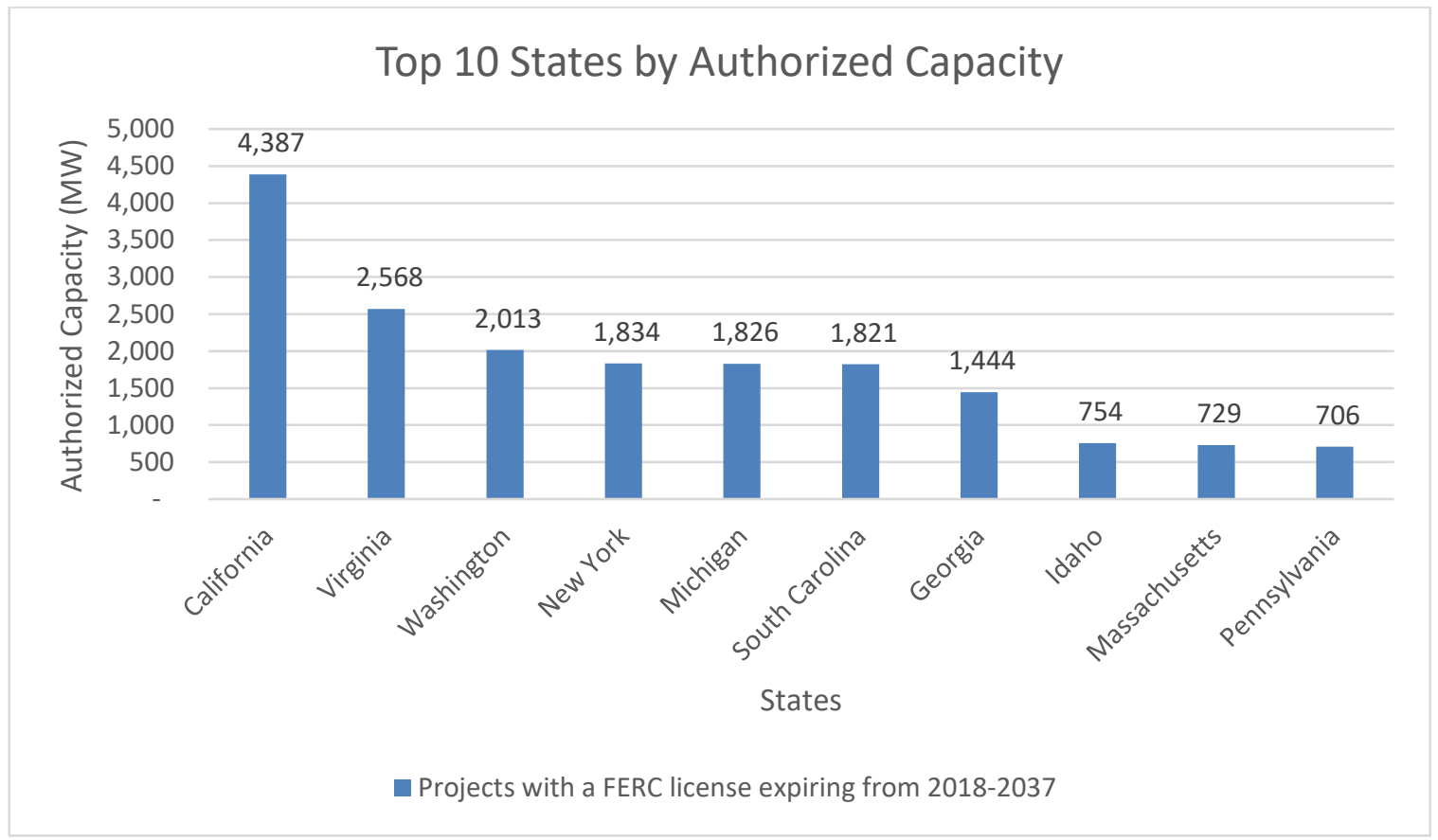

Figure 3. Top 10 states by authorized capacity-FERC-licensed projects with license expiration dates from 2018-2037

\subsubsection{Expected Relicensing Workload}

Figure 4 illustrates the total number of FERC filings (NOI or an application for a new license) expected through September 2032 in 5-year periods. This totals 1,012 expected relicensing filings through September 2032 (FERC 2017a). Of those total filings, FERC expects that 551 NOIs with PADs and 461 applications for a new license (FERC 2017a). The highest number of filings is expected between 2028 and September 2032. 


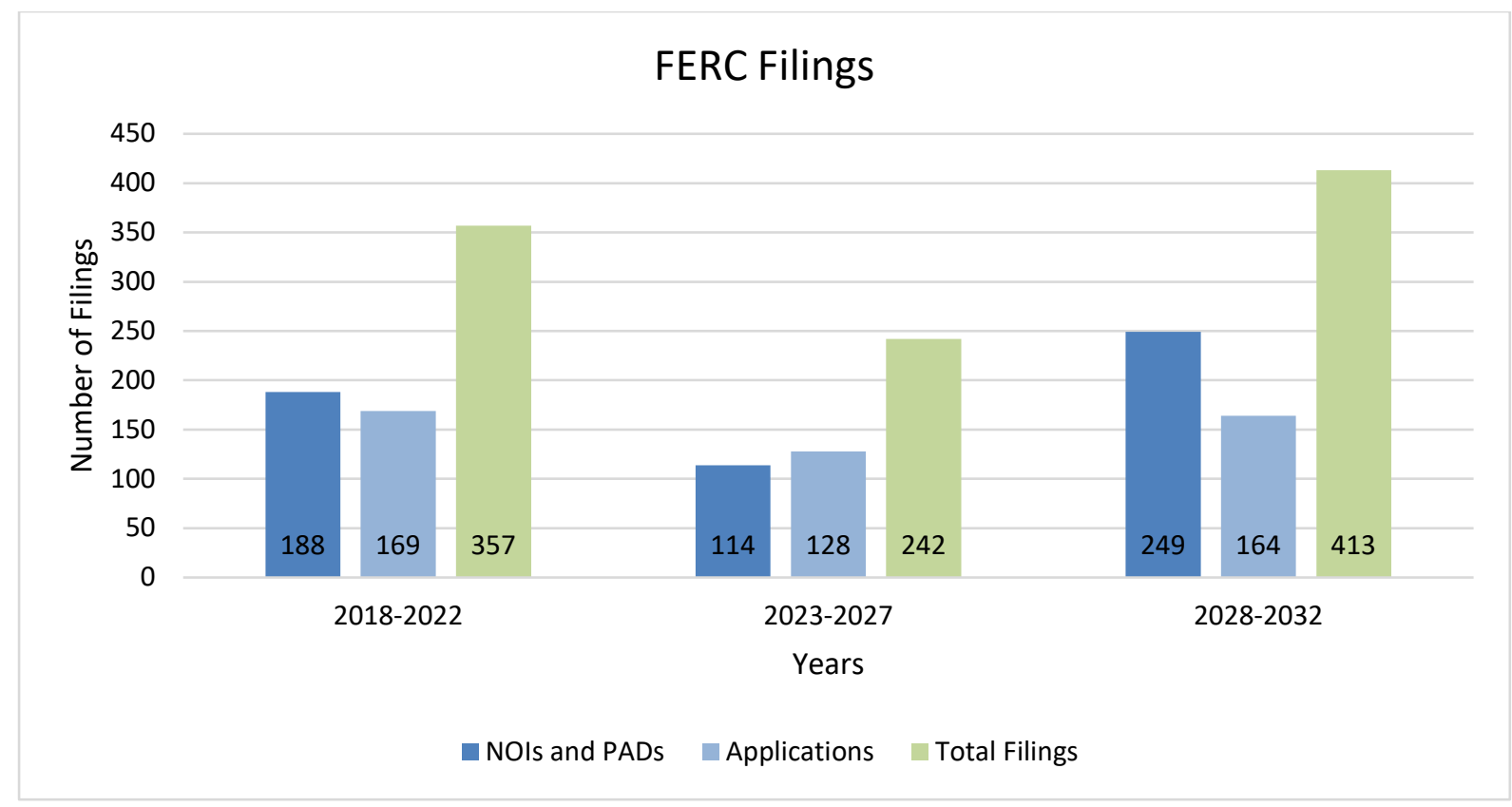

Figure 4. Expected FERC relicensing filings from 2018-2032

\subsubsection{Projects in a Shared River Basin or Sub-Basin}

To estimate the number of FERC-licensed hydropower projects coming up for relicense that are within a shared river basin or sub-basin this analysis integrates Oak Ridge National Laboratory's (ORNL) national hydropower plant data set (see Samu et al. 2018) with FERC relicensing information (see FERC 2017a). ORNL's dataset includes FERC-licensed projects and their corresponding geospatial hydrologic unit code (HUC), which maps the sub-basin where the project is located. ${ }^{6}$ Figure 5 illustrates the number of hydropower projects with FERC license expiration dates from 2018-2037 within a shared river basin or sub-basin in the 10 states with the highest number of projects that have FERC licenses due to expire through 2037 (i.e., New York, California, Wisconsin, New Hampshire, Maine, Idaho, Vermont, Michigan, Washington and Utah).

In New York, 69 FERC-licensed projects are coming up for relicense among 8 river basins or sub-basins. The river basin with the largest number of projects due to expire is the HudsonMohawk basin with a total of 21 FERC-licensed projects. ${ }^{7}$ In addition, 15 projects in the Raquette River basin and 13 projects in the Black River basin have FERC license expiration dates through 2037.

In Wisconsin, 68 FERC-licensed projects are coming up for relicense among 6 river basins or sub-basins. The river basin with the largest number of projects due to expire is the Wisconsin

${ }^{6}$ HUCs are delineated and georeferenced to U.S. Geological Survey topographic base maps according to compilation criteria monitored by the national Sub-Committee on Spatial Water Data (EPA 2018a). ORNL's data set includes HUC 8 maps that identify the spatial water data on a sub-basin level, analogous to medium-sized river basins (Samu et al. 2018).

${ }^{7}$ There are a number of tributaries to the basin that have FERC-licensed hydropower projects including, but not limited to, Schoharie Creek, Kinderhook Creek, Normans Kill, Fishkill Creek, West Canada Creek, and Fish Creek. 
River basin with a total of 19 projects. In addition, 17 projects coming up for relicense are in the Peshtigo River and Menominee River basin and 16 projects in the Chippewa River and Flambeau River basin.

In California, 50 FERC-licensed projects are coming up for relicense among 8 river basins or sub-basins. The river basin with the largest number of projects due to expire is the Feather River and Sacramento River basin with a total of 10 projects. $^{8}$ The river basin with the second largest number projects coming up for relicense is the Kings River and Kerns River basin with a total of 9 projects. The majority of the projects within the Kings River and Kerns River basin are owned by SCE or Pacific Gas and Electric Co.

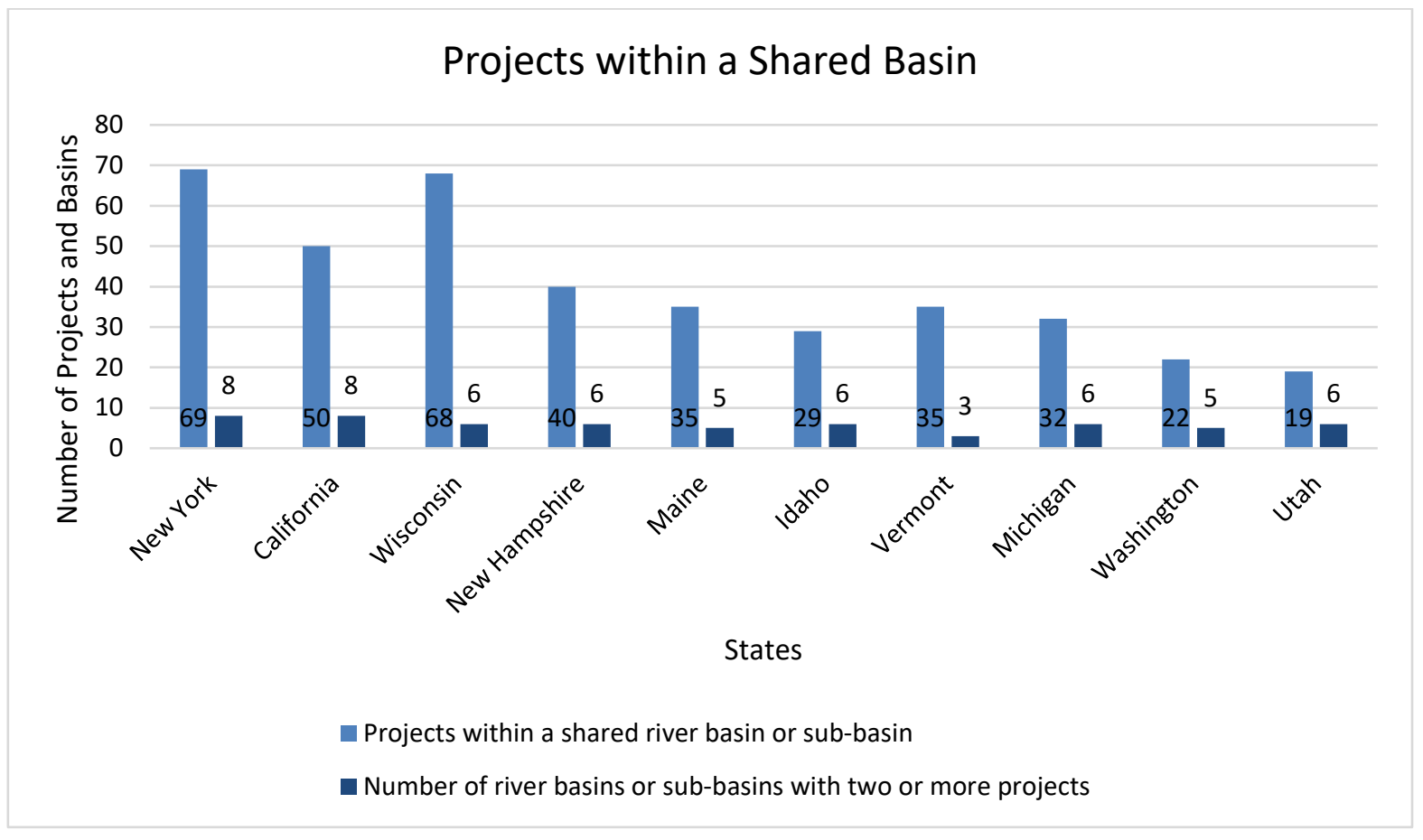

Figure 5. FERC-licensed projects with license expiration dates from 2018-2037 within a shared river basin or sub-basin

\footnotetext{
8 A number of tributaries to the basin have FERC-licensed hydropower projects including, but not limited to, Bucks Creek, Bear River, Battle Creek, Rock Creek, and Cottonwood Creek.
} 


\section{Coordinating FERC License Terms for Hydropower Projects Within a Shared River Basin}

At the time of relicense, FERC may set a license term to coordinate with other projects in the same waterway or a licensee may request a license term extension or acceleration to align a project's expiration date with other projects in a shared river basin. Aligning the relicensing schedule with other project(s) can reduce the volume of work that is required for two separate relicensing efforts that are on independent schedules. In addition, FERC has found that coordinating the license expiration dates of projects within a shared waterway can allow for a more comprehensive analysis of the cumulative environmental impacts of the projects (18 C.F.R. $§ 2.23$; FERC 1994).

\subsection{Accelerating or Extending License Terms}

FERC may grant a new hydropower license (relicense) for a term of 30-50 years (16 U.S.C. $\S$ 808 [e]). In 2017, FERC established a 40-year license term default for original and new licenses for hydropower projects located on non-federal dams. FERC may consider a shorter or longer term if:

- Issuing a shorter or longer term would align license terms for projects in the same river basin

- Stakeholders explicitly agreed to a shorter or longer term in a "generally supported" comprehensive settlement agreement, provided that such term does not conflict with coordination

- A longer license term is consistent with other license terms in the same basin, and the licensee requests a longer term "based on significant measures expected to be required under the new license or significant measures implemented during the prior license term."

(FERC 2017b)

FERC must address and consider the cumulative impacts of a project at relicense, but if that analysis results in unreasonable delays, FERC has the authority to issue a new license and then reopen the license afterwards to reconsider and mitigate the impacts (18 C.F.R. $§ 2.23$; FERC 1994). FERC established this policy in anticipation of a large influx of new license applications in 1994. FERC recognized that the pending workload could hinder the relicensing process, and that delay could harm the environment by postponing refurbishments or operational changes necessary to mitigate environmental harm (FERC 1994). By aligning the expiration dates of projects in a river basin, FERC can avoid using the reserved power of authority to reopen a license (18 C.F.R. $§ 2.23$; FERC 1994).

When issuing an original license or new license, FERC "will coordinate the expiration dates of the licenses to the maximum extent possible, to maximize future consideration of cumulative impacts" of multiple projects within a single river basin (18 C.F.R. $§ 2.23$; FERC 1994). ${ }^{9}$ In addition, a licensee may request that FERC accelerate or extend the expiration date of a hydropower license (18 C.F.R. § 2.23; FERC 1994). FERC may grant a license extension or

${ }^{9}$ FERC does not require "perfect" coordination but only "to the maximum extent possible" (Public Utility District No. 1 of Chelan County,_127 FERC \ 61,152 [2009]). 
acceleration request to allow for a more comprehensive analysis of cumulative environmental impacts of the projects within the basin.

\subsubsection{Non-Default FERC License Term Example}

In December 2015, Brookfield White Pine Hydro LLC (licensee) filed an application for a new license with FERC for the Williams Hydroelectric Project. The Williams Project is a 13-MW project located on the Kennebec River in Somerset County, Maine. In granting the license, FERC deviated from the established 40-year default term and issued a 36.5-year license to align the expiration date with two projects downstream of the Williams Project. FERC stated that the alignment would "maximize consideration of cumulative impacts" of the projects at the time of relicense (Brookfield White Pine Hydro LLC, 161 FERC 9 62,083 [2017]).

\subsubsection{FERC License Term Extension Examples}

\subsubsection{Cloquet Hydroelectric Project}

In late October 2017, Sappi Cloquet, LLC (licensee) filed a request with FERC to extend the license term of the Cloquet Hydroelectric Project (P-2363) 10 years from June 30, 2025, to June 30, 2035. The Cloquet Project is a 6.5-MW project located on the St. Louis River in Carlton County, Minnesota. The licensee stated that the license extension would allow them to align the project's expiration date with another project on the same river, the St. Louis River Project (P2360). Both projects received licenses in 1995, and although they are owned by different licensees, they are operated in a coordinated manner. In 1995, the St. Louis River Project received a 40-year term due to extensive mitigation measures needed, while the Cloquet Project received a default 30-year license term. Extending the Cloquet Project's license term would allow the licensee to align the relicensing timelines of the two projects. The licensee stated that the alignment would decrease costs, increase efficiency of the relicensing processes, and allow the stakeholders to comprehensively analyze the projects' effects simultaneously (Sappi Cloquet LLC, 162 FERC 92,087 [2018]). FERC approved the license term extension request for the Cloquet Project because it would "maximize the future consideration of cumulative and environmental impacts for both projects and would improve efficiency in each relicensing proceeding" (Sappi Cloquet LLC, 162 FERC 9 62,087 [2018]).

\subsubsection{Saxon Falls Project}

In July 2014, Northern States Power Company (licensee) filed a request with FERC to extend the license term of the Saxon Falls Project (P-2610) by 5 years from December 31, 2019, to December 31, 2024. The Saxon Falls Project is a 1.5-MW project located on the Montreal River in Wisconsin and Michigan. The licensee wanted to extend the license term to align the Saxon Falls Project's expiration date with the Superior Falls Project (P-2587) located 3.5 miles downstream. The Superior Falls Project was also owned and operated by the licensee. Both original licenses were granted for 30-year terms. The licensee claimed that aligning the project's expiration dates would increase the efficiency of the relicensing process and reduce the burden of stakeholder consultations.

In a comment to FERC regarding the license extension, the National Park Service requested that FERC instead accelerate the Superior Falls Project expiration date 5 years to achieve alignment. American Whitewater also commented on the National Park Service's proposal - acknowledging 
that the FPA prohibits FERC from setting license terms of less than 30 years but asked FERC to consider if there was "any flexibility in this regard." FERC denied the National Park Service's request and stated that if the licensee wanted to align the two projects, "the only option [was] to extend the term of the Saxon Falls license" because the FPA prohibits the issuance of new license terms for less than 30 years (Northern States Power Company, 149 FERC 9 62,090 [2014]).

\subsubsection{FERC License Term Acceleration Example}

In September 2013, the City of Holyoke Gas and Electric Department (licensee) filed a request with FERC to accelerate the license term of the Holyoke No. 3 Hydroelectric Project (P-2388) 1 year and 4 months from May 31, 2020, to January 31, 2019. The Holyoke No. 3 Project is a 450$\mathrm{kW}$ project located on the Connecticut River in northwestern Massachusetts. The licensee stated that the license term acceleration would allow them to align the relicensing activities and timelines of two other projects immediately downstream that they owned-Holyoke No. 1 (P2386) and Holyoke No. 2 (P-2387). Further, the licensee stated that combining the relicensing activities for all three projects would result in substantial savings to the licensee who owned and operated all three projects and that it would provide for a more effective consultation with the resource agencies and other stakeholders. FERC approved the license term acceleration request for the Holyoke No. 3 Project, stating that "combining the relicensing activities for all three projects should assist the licensee, resource agencies, interested stakeholders, and the FERC staff in participating and reviewing all three projects" (City of Holyoke Gas and Electric Department, 145 FERC \ 62,131 [2013]).

\subsubsection{FERC License Term Acceleration and Extension Example}

In May 2017, Erie Boulevard Hydropower, L.P. (licensee) filed a request with FERC to extend the license term for the Yaleville Hydroelectric Project (P-9222) and to accelerate the license term of the Piercefield Hydroelectric Project (P-7387). The licensee requested that FERC extend the 30-year license term for the Yaleville Project (2.7 MW) approximately 12 years, from January 31, 2022 to December 31, 2033, and accelerate the 40-year license term for the Piercefield Project (1.5 MW) by 10 years, from October 31, 2045 to October 31, 2035. Both projects are located with four other projects owned by the licensee on the Raquette River in New York with licenses expiring on December 31, 2033. The licensee stated that the "requested license term adjustments would allow it to coordinate the relicensing activities of all its Raquette River projects and would allow for a settlement agreement with stakeholders that addresses the river basin as a whole." FERC approved the license term adjustments for both projects stating that "the alignment would allow FERC, resource agencies, and stakeholders to perform a more comprehensive analysis of the cumulative environmental impacts of the projects and increase the efficiency during the relicensing process for all of the licensee's Raquette River projects" (Erie Boulevard Hydropower, L.P., 161 FERC 9 62,021 [2017]). 


\section{Basin-Wide Considerations to Relicense}

Basin-wide approaches have been used in various aspects of hydropower development for decades. Federal and state regulators, licensees, and other stakeholders have a long history of utilizing basin-wide approaches for resource planning and assessments as well as for resource review and impact analyses.

Most recently, federal and state resource agencies and licensees have begun to apply a basinwide approach to aspects of the hydropower relicensing process. With more than half of the FERC-licensed hydropower fleet coming up for relicense, initiatives in states such as California, Maine, New York, and Wisconsin seek to improve the efficiency of the relicensing process. Regulators and licensees in these states are working together to coordinate different aspects of the relicensing process for multiple hydropower projects within a shared watershed or basin.

These basin-wide approaches involve different levels of coordination and collaboration, which seek to improve the efficiency of the relicensing process as well as allow for a more comprehensive analysis of the cumulative impacts of the projects within the basin. Initiatives in California and Maine seek to coordinate the review and issuance of Section 401 water quality certifications for multiple hydropower projects within a shared basin that are owned and operated by the same licensee. While initiatives in New York and Wisconsin take a more comprehensive basin-wide approach to relicensing by coordinating the timelines of multiple hydropower projects owned by different licensees.

\subsection{History}

As early as the 1960s, FERC began using planning status reports to track planning studies for non-federal hydropower developments that were organized by basin (Saulsbury et al. 2010). ${ }^{10}$ Other federal entities such as the Tennessee Valley Authority and the U.S. Bureau of Reclamation also have a long history of planning and assessing hydropower at the basin level (Saulsbury et al. 2010). ${ }^{11}$

In addition, basin-wide studies and analyses have been used by licensees and federal and state resource agencies during hydropower relicensing. During the relicensing process for a Penobscot River project in Maine, the licensee, the Penobscot Indian Nation, six conservation groups, and federal and state agencies signed an agreement to balance energy production in the Penobscot River basin with competing water uses (Saulsbury et al. 2010). The 2005 agreement aimed to restore anadromous fish populations, renew the Penobscot Indian Nation's sustenance fishing rights, and create new tourism and business opportunities through stable and consistent management of the river (Saulsbury et al. 2010).

\footnotetext{
${ }^{10}$ These reports turned compilations of existing information about hydropower projects into quick summaries of the relevant issues within a single basin (Saulsbury et al. 2010).

11 TVA's Programmatic Environmental Impact Statement: Reservoir Operations Study evaluated 35 projects in the Tennessee and Cumberland River watersheds to determine whether they could increase the public value of their reservoir system operations (Saulsbury et al. 2010). U.S Bureau of Reclamation's Basin Studies Program utilizes basin-wide approaches to identify risks and impacts to the agency's ability to deliver water and power while maintaining its ecological responsibilities (Saulsbury et al. 2010).
} 
Example: In Oregon, a hydropower project can trigger a cumulative, basin-wide review if the Director of the Oregon Water Resources Commission "determines the project may have unacceptable cumulative impacts" (OR. ADMIN. R. § 690-051-0290[2]). A basin-wide review considers all existing, approved, and proposed projects in the same river basin (OR. ADMIN. R. $\S$ 690-051-0290[2]).

\subsection{Comprehensive Basin-Wide Approaches to Relicense}

The case studies detailed in this section discuss two innovative approaches to hydropower relicensing. In both New York and Wisconsin, licensees and regulators are working on a comprehensive approach to relicense and manage hydropower as part of a larger system - a river basin. ${ }^{12}$ Both initiatives intend to align the license expiration dates of multiple projects, owned and operated by different licensees, within a shared river basin to coordinate project relicensing timelines.

Aligning the relicensing timelines allows for coordination and collaboration among the different licensees that seek to streamline consultation, study analyses, and project reviews. These basinwide approaches intend to reduce the costs associated with the relicensing process and provide a more comprehensive analysis of the cumulative environmental impacts of the projects. In addition, considering the environmental objectives, long-term hydrological changes, and other complementary or competing water uses of a basin during relicensing may allow owners and operators to work together to create holistic management plans that reduce risk and increase resiliency (Oakley 2018). The information for the case studies was obtained primarily through interviews with hydropower project licensees and federal and state regulators.

\subsubsection{New York Black River Basin-Wide Relicensing Pilot}

In New York, regulators and licensees are working together to pioneer one of the nation's first comprehensive basin-wide approaches to hydropower relicensing. Recognizing the large number of FERC-licensed hydropower projects due to expire in the coming years, the New York State Department of Environmental Conservation (NYSDEC) and USFWS have devised a strategy to handle the pending relicensing workload. NYSDEC and USFWS have identified five licensees as potential participants in a basin-wide relicensing pilot for eight hydropower projects (21 total developments) ${ }^{13}$ in the Black River Basin in New York. ${ }^{14}$ The potential pilot could serve as a model for other NYSDEC regions (Christopher Hogan, New York State Department of Environmental Conservation, email, June 25, 2018).

\footnotetext{
12 Other states such as Vermont are in the beginning stages of considering a basin-wide approach to hydropower relicensing. Vermont is working on a basin-wide relicensing strategy for multiple projects within a single river basin that would assess the projects' cumulative impacts on flow, water quality, aquatic habitat, and fish passage (Jeff Crocker, Vermont Department of Environmental Conservation, email, July 10, 2018; August 15, 2018).

13 "Development" refers to the dams and powerhouses associated with a hydroelectric project. A hydroelectric project can have multiple developments.

${ }^{14}$ As of November 2018, no formal agreements or commitments to participate in the basin-wide relicensing pilot have been made.
} 


\subsubsection{Hydropower Relicensing in New York}

There are 75 FERC-licensed hydropower projects in New York, with a total combined generating capacity of 1,834 MW with licenses set to expire between 2018-2037 (FERC 2017a). The largest number of hydropower projects coming up for relicense are in NYSDEC's Region 6 in Herkimer, Jefferson, Lewis, Oneida, and St. Lawrence counties in northern New York (Jessica Hart, New York State Department of Environmental Conservation Region 6, and John Wiley, U.S. Fish and Wildlife Service, telephone conference, August 7, 2018).

\section{Black River Basin}

The majority of the hydropower projects up for relicense in NYSDEC's Region 6 are located within the Black River Basin. Ten FERC-licensed hydropower projects (24 total developments) in the Black River Basin have either started the relicensing process or are expected to begin the relicensing process by 2027 (NYSDEC 2017). Figure 6 illustrates the expected Black River Basin relicensing workload from 2018-2027. The highest number of projects going through the relicensing process are expected to be in 2021-2023. A total of 9 projects and 21 corresponding developments are projected to be in some stage of the relicensing process in 2021 (Wiley 2015).

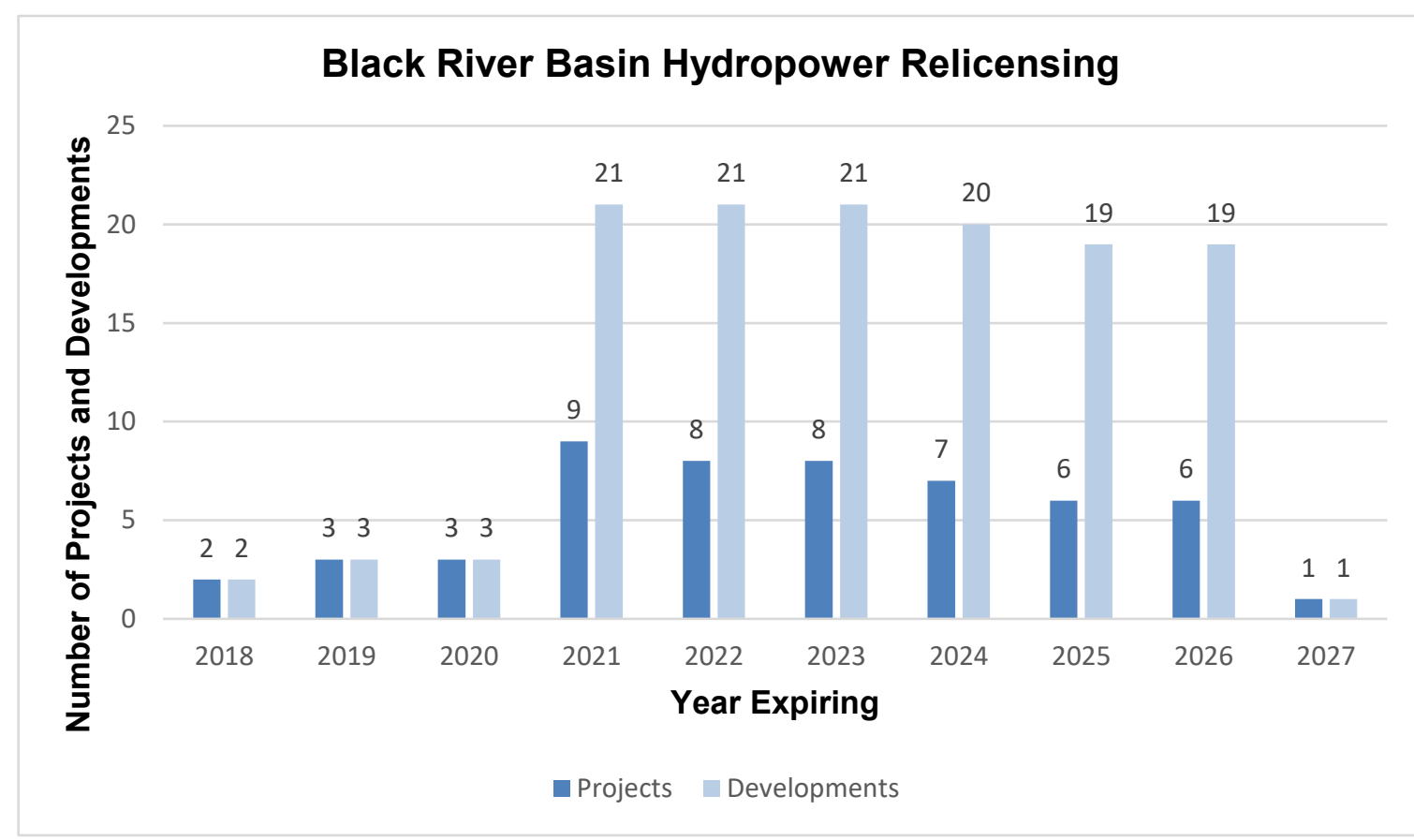

Figure 6. Black River Basin hydropower relicensing workload—projects and developments

\subsubsection{Implementation History and Process}

In late 2014 and early 2015, USFWS initially identified nine projects (22 total developments) with six different licensees within the Black River Basin ${ }^{15}$ with license expiration dates between 2026 and 2031 (Jessica Hart, New York State Department of Environmental Conservation

\footnotetext{
15 The Black River Basin is located in north-central New York State where it drains the western slopes of the Adirondack Mountains and flows 180 miles to the eastern edge of the Tug Hill Plateau before emptying into Lake Ontario near Watertown. The major tributaries to the Black River Basin include the Black River, the Moose River, and the Beaver River (NYSDEC 2004).
} 
Region 6, and John Wiley, USFWS, telephone conference, August 7, 2018). NYSDEC and USFWS representatives first visited the nine hydropower projects identified as well as other FERC-licensed and exempt projects within the basin (Jessica Hart, New York State Department of Environmental Conservation Region 6, and John Wiley, U.S. Fish and Wildlife Service, telephone conference, August 7,2018). The site visits gave the resource agencies a better understanding of the hydropower projects, their location, and the overall demands on the ecology of the river basin (Jessica Hart, New York State Department of Environmental Conservation Region 6, and John Wiley, U.S. Fish and Wildlife Service, telephone conference, August 7, 2018). Figure 7 identifies hydropower projects, by development, within the Black River Basin.

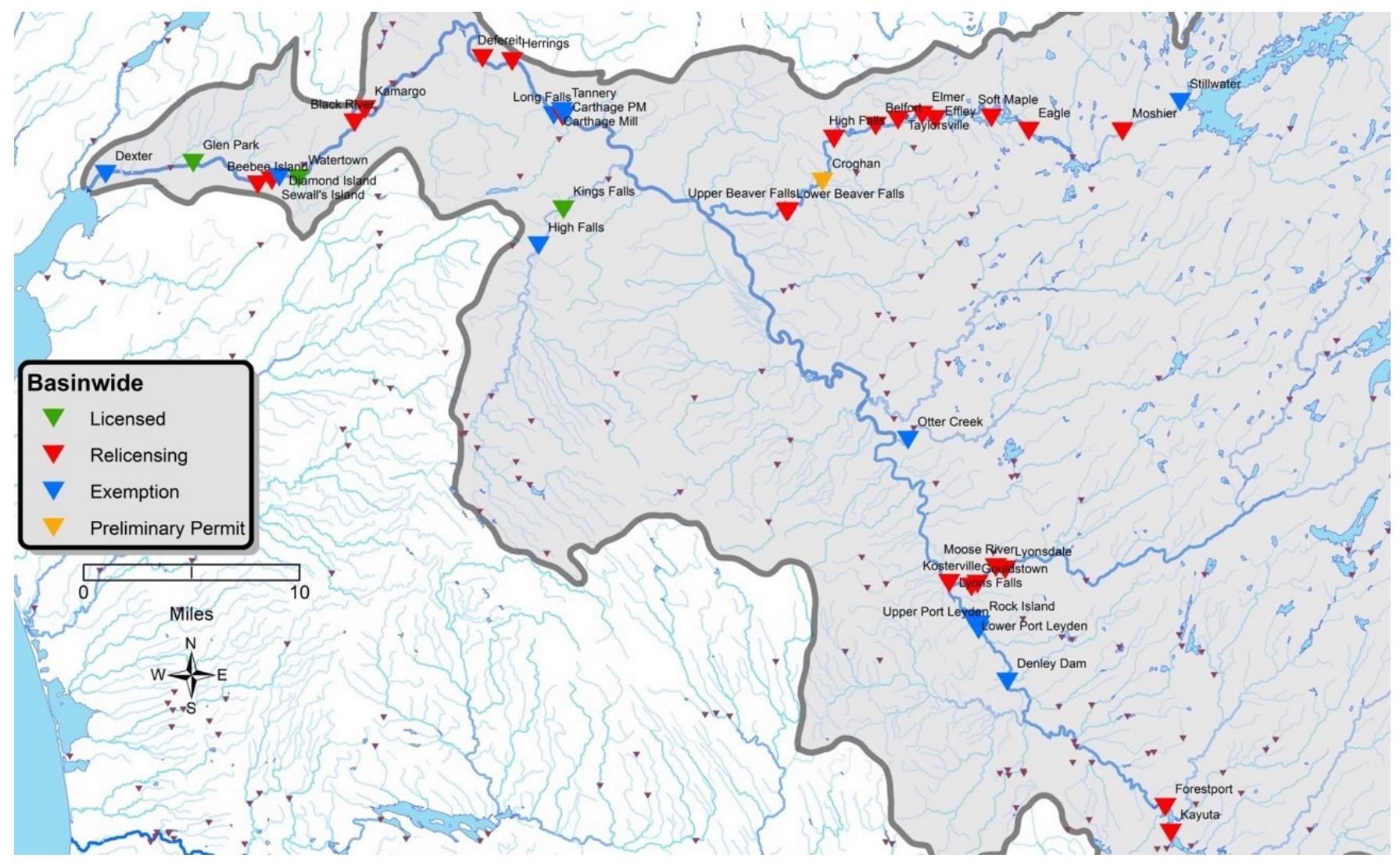

Figure 7. Black River Basin pilot: map of hydropower projects

Recognizing the number of hydropower projects up for relicense and the proximity of these projects to one another, USFWS and NYSDEC discussed potential relicensing strategies with FERC and then forged the idea of a basin-wide approach. Table 2 identifies the nine hydropower projects initially identified in the Black River Basin as potential projects for the pilot. 
Table 2. Black River Basin Pilot: Initial Projects Identified

\begin{tabular}{|c|c|c|c|c|c|}
\hline $\begin{array}{l}\text { Project } \\
\text { Name }\end{array}$ & Licensee & Waterway & $\begin{array}{l}\text { Basin } \\
\text { Location }\end{array}$ & $\begin{array}{l}\text { License } \\
\text { Issuance } \\
\text { Date }\end{array}$ & $\begin{array}{l}\text { License } \\
\text { Expiration } \\
\text { Date }\end{array}$ \\
\hline $\begin{array}{l}\text { Beaver River } \\
(\mathrm{P}-2645)\end{array}$ & Erie Boulevard & Beaver River & Northeast & 08/02/1996 & $07 / 31 / 2026$ \\
\hline $\begin{array}{l}\text { Beebee Island } \\
(\mathrm{P}-2538)\end{array}$ & Erie Boulevard & Black River & Northwest & 12/24/1996 & $11 / 30 / 2026$ \\
\hline $\begin{array}{l}\text { Black River } \\
\text { (P-2569) }\end{array}$ & Erie Boulevard & Black River & Northwest & 12/24/1996 & $11 / 30 / 2026$ \\
\hline $\begin{array}{l}\text { Forestport } \\
\text { (P-4900) }\end{array}$ & $\begin{array}{l}\text { Ampersand } \\
\text { Energy }\end{array}$ & $\begin{array}{l}\text { Black River } \\
\text { Canal }\end{array}$ & Southeast & 03/20/1987 & $02 / 28 / 2027$ \\
\hline $\begin{array}{l}\text { Moose River } \\
(\mathrm{P}-4349)\end{array}$ & $\begin{array}{l}\text { EONY } \\
\text { Generation } \\
\text { Limited }\end{array}$ & Moose River & Southcentral & 05/06/1986 & $04 / 30 / 2026$ \\
\hline $\begin{array}{l}\text { Lyons Falls } \\
\text { (P-2548) }\end{array}$ & $\begin{array}{l}\text { Northbrook } \\
\text { Lyons Falls }\end{array}$ & Moose River & Southcentral & 05/06/1986 & $05 / 31 / 2026$ \\
\hline $\begin{array}{l}\text { Lyonsdale } \\
\text { (P-3255) }\end{array}$ & $\begin{array}{l}\text { Lyonsdale } \\
\text { Associates }\end{array}$ & Moose River & Southcentral & 05/23/1983 & $05 / 31 / 2026$ \\
\hline $\begin{array}{l}\text { Kayuta Lake } \\
(P-5000)\end{array}$ & $\begin{array}{l}\text { Ampersand } \\
\text { Energy }\end{array}$ & Black River & Southeast & 09/12/1984 & $05 / 31 / 2026$ \\
\hline $\begin{array}{l}\text { Carthage } \\
\text { (P-10887) }\end{array}$ & $\begin{array}{l}\text { Carthage } \\
\text { Paperboards } \\
\text { LLC }\end{array}$ & Black River & Northwest & 11/22/1991 & $10 / 31 / 2021$ \\
\hline
\end{tabular}

Source: FERC 2017a

\section{Outreach}

In 2016, NYSDEC and USFWS contacted the six licensees of the nine projects initially identified to explain the basin-wide pilot concept and to gauge the licensees' interest (Jessica Hart, New York State Department of Environmental Conservation Region 6, and John Wiley, U.S. Fish and Wildlife Service, telephone conference, August 7, 2018). Later that year, NYSDEC and USFWS held a meeting with the licensees to solicit feedback and continue discussions regarding the proposal (Jessica Hart, New York State Department of Environmental Conservation Region 6, and John Wiley, U.S. Fish and Wildlife Service, telephone conference, August 7, 2018). NYSDEC and USFWS also engaged other stakeholders including federal and state resource agencies, non-governmental organizations, conservation organizations, county officials, towns, and villages (Jessica Hart, New York State Department of Environmental Conservation Region 6, and John Wiley, U.S. Fish and Wildlife Service, telephone conference, August 7, 2018). 


\subsubsection{Pilot Details}

After internal meetings and discussions with FERC in early 2016, USFWS and NYSDEC outlined the basin-wide approach to hydropower relicensing concept for the Black River Basin (Jessica Hart, New York State Department of Environmental Conservation Region 6, and John Wiley, U.S. Fish and Wildlife Service, telephone conference, August 7, 2018). The major coordinated relicensing steps include:

- Licensees submit requests to FERC to align license expiration dates for all projects with NYSDEC and USFWS support

- Licensees and agencies develop a collaborative Alternative Licensing Process (ALP) with communication protocol and coordinated timelines

- NYSDEC and USFWS develop a basin-wide study protocol to utilize for all the projects

- Licensees prepare a joint PAD for all licensees to file

- Licensees file an NOI and joint PAD at the same time

- Licensees conduct studies and prepare a joint study report

- Licensees file the joint study report at the same time

- Stakeholders negotiate a settlement agreement(s)

- Licensees file new license applications with FERC

- FERC issues additional informational requests (AIRs), REAs, and notice and comments for all projects

- FERC issues licenses for all projects

(Hart 2017; Jessica Hart, and John Wiley, telephone conference, August 7, 2018).

The basin-wide approach would require the licensees to develop and file their own NOI, sitespecific studies, and separate license applications with FERC (Hart 2017; Jessica Hart, New York State Department of Environmental Conservation Region 6, and John Wiley, U.S. Fish and Wildlife Service, telephone conference, August 7, 2018). Figure 8 outlines the proposed timeline for the basin-wide relicensing pilot.

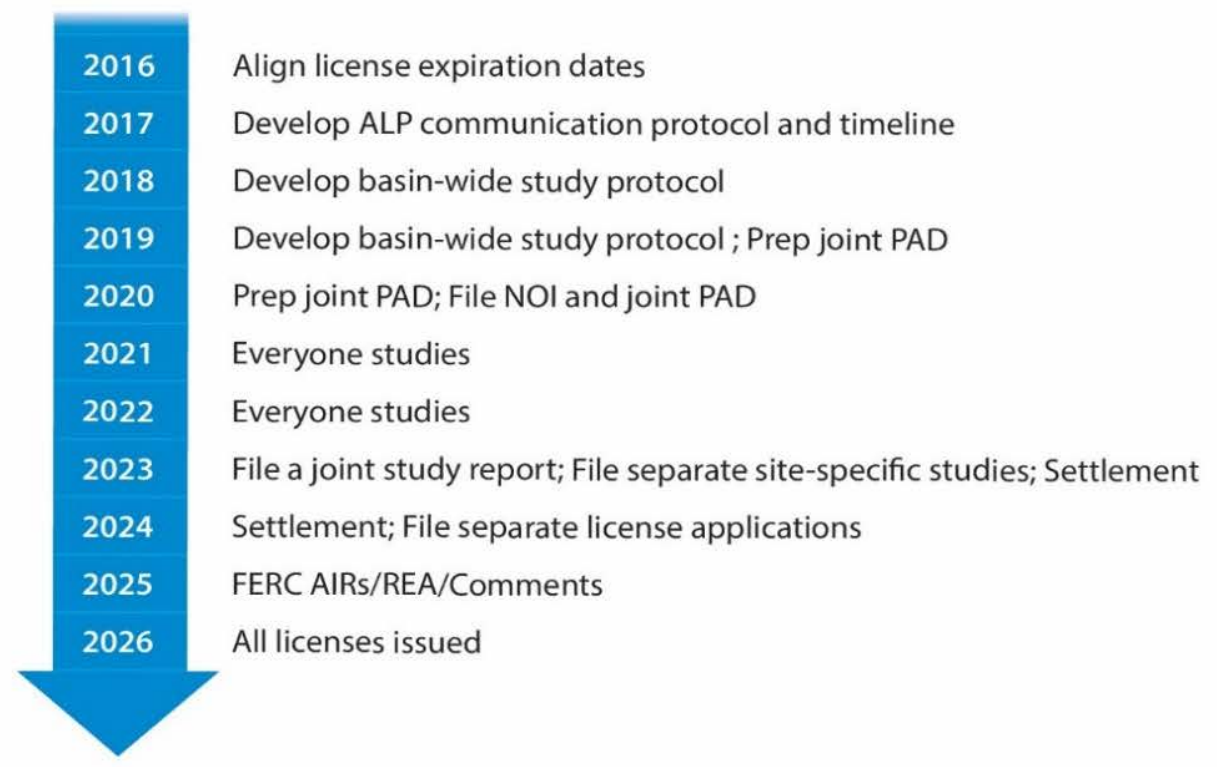

Figure 8. Black River Basin pilot: basin-wide relicensing timeline 


\section{Developing a Collaborative Communication Protocol and Coordinated Timelines}

The basin-wide pilot proposes that the licensees utilize the ALP for relicense. The ALP is designed to, among other things, encourage upfront communication and coordination among stakeholders, increase participation and cooperation among stakeholders, provide more flexibility, streamline pre-filing and administrative processes into a single step, and implement other time- and resource-saving measures (18 C.F.R. $§ 4.34[\mathrm{i}][2][\mathrm{i}]-[\mathrm{v}]){ }^{16}$

For example, the ALP requires early coordination among the licensees and the resource agencies to identify stakeholders that may have an interest in the relicensing efforts (18 C.F.R. $\S$ 4.34[i][3]). The licensees, resource agencies, and other stakeholders form a collaborative group that must develop a communication protocol that governs how participants in the pre-filing consultation process will communicate with each other regarding the merits and recommendations of the proposal (18 C.F.R. § 4.34[i][3][ii]). The ALP also allows the licensees and the collaborative group to set the filing timelines dictating the relicensing schedule (Jessica Hart, New York State Department of Environmental Conservation Region 6, and John Wiley, U.S. Fish and Wildlife Service, telephone conference, August 7, 2018; 18 C.F.R. $§ 4.34[i]) .{ }^{17}$ With the ALP, scoping under NEPA is conducted during the pre-filing consultation process. The ALP also requires that the collaborative group develop the study plan collectively (FERC 2004).

Consideration: Because of its collaborative process, the ALP may be particularly useful if a settlement agreement is being sought (FERC 2004).

\section{Basin-Wide Study Protocol}

USFWS and NYSDEC are in the early stages of putting together a basin-wide study protocol proposal for the hydropower relicensing pilot. The protocol would be utilized to inform the study plan. After developing a protocol, the resource agencies expect to work for at least 1 year with the licensees and other stakeholders to finalize the details of the study plan. The study protocol will include, at a minimum, analysis regarding:

- Diadromous fish species

- Fisheries

- Fish passage

- Water quality for bypass reaches and downstream of each hydropower project

- Mussel species

- Macro-invertebrates

- Impoundments fluctuations

- Recreation

- Flows and run-of-river compliance

\footnotetext{
${ }^{16}$ For more information on the FERC license authorization processes, see Aaron Levine and Austin Flanagan. Forthcoming. "FERC Hydropower Licensing: A Review of the ILP, TLP, and ALP." NREL/TP-6A20-71982. Golden, CO: National Renewable Energy Laboratory.

${ }^{17}$ FERC prescribes the filing timeline for all participants in the Integrated Licensing Process and for some participants in the Traditional Licensing Process (18 C.F.R. $\S 4.30-4.61,5)$.
} 
- Wetlands

- Analysis of cumulative impacts.

(Jessica Hart, New York State Department of Environmental Conservation Region 6, and John Wiley, U.S. Fish and Wildlife Service, telephone conference, August 7, 2018)

Consideration: The basin-wide study analysis could be used to inform Section 10(j) resource agency recommendations, Section 10(a) comprehensive plan considerations, and Section 18 fish prescriptions pursuant to the FPA, as well as environmental review under NEPA, Section 401 water quality certification for CWA compliance, and Section 7 species review under the ESA (Jessica Hart, New York State Department of Environmental Conservation Region 6, and Jonathan Binder, New York State Department of Environmental Conservation, telephone conference, July 9, 2018; Jessica Hart, New York State Department of Environmental Conservation Region 6, email, August 1, 2018).

\section{Aligning License Expiration Dates}

To align the relicensing timelines for all nine of the initially identified hydropower projects, the licensees for the Carthage Paper Makers Hydroelectric Project, the Kayuta Lake Hydroelectric Project, and the Lyonsdale Hydroelectric Project all filed requests with FERC to extend their project's license term to May 31, 2026. FERC granted the license term extension for both the Lyonsdale Project and the Kayuta Lake Project but denied the license term extension for the Carthage Paper Makers Project.

Consideration: The license term extension requests for all three projects used similar language when explaining the basin-wide approach and the reasons for the license term extension. Each request was accompanied by letters of support from USFWS and NYSDEC.

\section{Carthage Paper Makers Hydroelectric Project (P-10887)}

In August 2016, Carthage Specialty Paperboard Inc. ${ }^{18}$ filed a request with FERC to extend the Carthage Paper Makers Hydroelectric Project license term approximately 5 years from October 31, 2021, to May 31, 2026 (Carthage 2016). FERC denied the license term extension because the Carthage Project license term was originally set at 50 years. Section 6 of the FPA allows FERC to issue a license for a maximum term of 50 years (18 C.F.R. $§ 799$ [2012]). Therefore, FERC was statutorily prohibited from extending the term of the license (Climax Manufacturing Co., 156 FERC ๆ 62,197 [2016]).

In 1991, FERC issued the Carthage Project a 30-year license, which would have typically allowed FERC to approve the license term extension. However, in the 1991 license order, FERC found that the project should have been originally licensed in 1964 - the year the Black River was found navigable. Because the project should have been previously licensed, FERC backdated the effective date of the license 20 years. Therefore, the 1991 license that was issued for 30 years was considered the maximum 50-year term permitted under the FPA (Climax Manufacturing Co., 57 FERC \% 62,145 [1991]).

\footnotetext{
${ }^{18}$ Carthage Specialty Paperboard Inc. was formerly Climax Manufacturing Co.
} 


\section{Kayuta Lake Hydroelectric Project (P-5000) and Lyonsdale (P-3255)}

In early January 2017, Ampersand Kayuta Lake Hydro, LLC filed a request with FERC to extend the license term of the Kayuta Lake Hydroelectric Project approximately 2 years from August 31, 2024, to May 31, 2026. Similarly, in late January 2017, Lyonsdale Associates, LLC filed a request with FERC to extend the license term of the Lyonsdale Hydroelectric Project approximately 3 years from February 28, 2023, to May 31, 2026. Both licensees stated that the license extensions would allow their respective projects to align with other projects within the Black River Basin that expire in 2026 or $2027 .{ }^{19}$ Further, the licensees stated that aligning the license terms would allow them to participate in a basin-wide initiative that sought to streamline the relicensing process, lower costs, and provide a comprehensive environmental analysis (Ampersand 2017; Ampersand Kayuta Lake Hydro, LLC 160 FERC 9 62,066 [2017]; Lyonsdale Associates, LLC 160 FERC 9 62,181 [2017]).

FERC approved the license term extension requests for both the Kayuta Lake Project and the Lyonsdale Project. FERC reasoned that "aligning the expiration dates of the projects would allow FERC, resource agencies, and stakeholders to perform a more comprehensive analysis of the cumulative environmental impacts of the projects and increase the efficiency of the relicensing process of all the projects" (Ampersand Kayuta Lake Hydro, LLC 160 FERC 9 62,066 [2017]; Lyonsdale Associates, LLC 160 FERC ๆ 62,181 [2017]).

\section{Forestport Hydroelectric Project (P-4000)}

Ampersand Energy Partners would need to accelerate the license term of the Forestport Project approximately 3 months to participate in the basin-wide relicensing pilot. The earliest an applicant (licensee) can file an NOI and PAD with FERC is 5.5 years before the license term expires, and the latest a licensee can file is 5 years before the license term expires (18 C.F.R. $\S$ 5.5). The Forestport Project license term expires February 28, 2027, and the other projects' license terms expire mid- to late 2026. Ampersand has stated that they would consider accelerating the Forestport Project license term, when the time came, to gain the potential benefits associated with the basin-wide relicensing approach (Sayad Moudachirou, Ampersand Energy Partners, LLC, telephone conference, August 6, 2018).

\subsubsection{Project and Licensee Characteristics}

This section identifies the similarities and differences of the hydropower projects and licensees within the Black River Basin that may participate in the basin-wide relicensing pilot.

\section{Project Characteristics}

The eight hydropower projects in the Black River Basin that have license terms ending in 2026 or 2027 vary in size, annual production, basin location, and operating mode. Table 3 highlights

\footnotetext{
${ }^{19}$ See Lawrence R. Taft, 38 FERC $\mid$ 62,293 (1987) (Forestport Project expiring February 28, 2027); Georgia-Pacific Corporation, 35 FERC 9 62,229 (1986) (Lyons Falls Project expiring May 31, 2026); Niagara Mohawk Power Corporation, 77 FERC 9 61,306 (1996) (Black River Project expiring November 30, 2026); and Beebee Island Corporation, 77 FERC \ 61,305 (1996) (Beebee Island Water Power Project expiring November 20, 2026); Long Lake Energy Corporation, 35 FERC $\mid 62,230$ (1986) (Moose River Project expiring April 30, 2026) and Amperand Kayuta Lake Hydro, LLC, 160 FERC $\$$ 62,066 (2017) (Kayuta Lake Project expiring May 31, 2026).
} 
some of the characteristics of each hydropower project that is eligible to participate in the proposed basin-wide relicensing pilot.

Table 3. Black River Basin Pilot: Project Characteristics

\begin{tabular}{llclll}
\hline $\begin{array}{l}\text { Project } \\
\text { Name }\end{array}$ & $\begin{array}{l}\text { Operating } \\
\text { Mode }\end{array}$ & $\begin{array}{l}\text { Number of } \\
\text { Developments }\end{array}$ & $\begin{array}{l}\text { Generation } \\
\text { Capacity } \\
\text { (MW) }\end{array}$ & $\begin{array}{l}\text { Annual } \\
\text { Production } \\
\text { (MWH) }\end{array}$ & $\begin{array}{l}\text { Basin } \\
\text { Location }\end{array}$ \\
\hline $\begin{array}{l}\text { Beaver } \\
\text { River } \\
\text { (P-2645) }\end{array}$ & $\begin{array}{l}\text { Storage and } \\
\text { Release }\end{array}$ & 8 & 44.80 & 245,610 & Northeast \\
$\begin{array}{l}\text { Beebee Island } \\
\text { (P-2538) }\end{array}$ & $\begin{array}{l}\text { Modified } \\
\text { Run-of-River }\end{array}$ & 1 & 8.00 & 51,881 & Northwest \\
$\begin{array}{l}\text { Black } \\
\begin{array}{l}\text { River } \\
\text { (P-2569) }\end{array}\end{array}$ & $\begin{array}{l}\text { Modified } \\
\text { Run-of-River }\end{array}$ & 5 & 29.60 & 158,827 & Northwest \\
$\begin{array}{l}\text { Forestport } \\
\text { (P-4900) }\end{array}$ & Run-of-River & 1 & 3.30 & 9,286 & Southeast \\
$\begin{array}{l}\text { Moose River } \\
\text { (P-4349) }\end{array}$ & Run-of-River & 1 & 12.20 & 65,063 & Southcentral \\
\hline $\begin{array}{l}\text { Lyons } \\
\text { Falls } \\
\text { (P-2548) }\end{array}$ & Run-of-River & 3 & 14.35 & Privileged & Southcentral \\
$\begin{array}{l}\text { Lyonsdale } \\
\text { (P-3255) }\end{array}$ & Run-of-River & 1 & 3.00 & 13,368 & Southcentral \\
\hline $\begin{array}{l}\text { Kayuta Lake } \\
\text { (P-5000) }\end{array}$ & Run-of-River & 1 & 0.40 & 1,394 & Southeast \\
\hline
\end{tabular}

Source: FERC 2017a

\section{Licensee Characteristics}

The five licensees of the projects that could participate in the Black River basin-wide hydropower relicensing pilot vary in company size and type. Erie Boulevard, LLC, a subsidiary of Brookfield Renewable Partners, is the largest independent power producer in the river basin owning and operating over 200 hydroelectric plants worldwide totaling 3,247 MW (Brookfield Renewable 2017). Ampersand Energy Partners is a much smaller independent power producer, owning and operating 18 hydropower projects totaling $29 \mathrm{MW}$ (Ampersand Energy 2018). Table 4 highlights some of the licensee characteristics of each hydropower project that could participate in the basin-wide relicensing pilot.

\footnotetext{
${ }^{20}$ Generation capacity is the authorized generation capacity per FERC record.

${ }^{21}$ Annual production is based on the most recent annual generation report filed with FERC.
} 
Table 4. Black River Basin Pilot: Licensee Characteristics

\begin{tabular}{|c|c|c|c|c|c|c|}
\hline Licensee & $\begin{array}{l}\text { Licensee } \\
\text { Parent } \\
\text { Company }\end{array}$ & Project Name & Owner/Operator & $\begin{array}{l}\text { Licensee } \\
\text { Type }\end{array}$ & $\begin{array}{l}\text { Total } \\
\text { Capacity } \\
\text { Owned } \\
(\mathrm{MW})^{22}\end{array}$ & $\begin{array}{l}\text { Asset } \\
\text { Location }\end{array}$ \\
\hline \multirow[t]{3}{*}{$\begin{array}{l}\text { Erie } \\
\text { Boulevard }\end{array}$} & \multirow[t]{3}{*}{$\begin{array}{l}\text { Brookfield } \\
\text { Renewable } \\
\text { Energy }\end{array}$} & $\begin{array}{l}\text { Beaver River } \\
(P-2645)\end{array}$ & \multirow[t]{3}{*}{ Owner/Operator } & \multirow[t]{3}{*}{$\begin{array}{l}\text { Independent } \\
\text { Power } \\
\text { Producer }\end{array}$} & \multirow[t]{3}{*}{4,247} & \multirow[t]{3}{*}{$\begin{array}{l}\text { National and } \\
\text { International }\end{array}$} \\
\hline & & $\begin{array}{l}\text { Beebee Island } \\
\text { (P-2538) }\end{array}$ & & & & \\
\hline & & $\begin{array}{l}\text { Black River } \\
\text { (P-2569) }\end{array}$ & & & & \\
\hline \multirow[t]{2}{*}{$\begin{array}{l}\text { Ampersand } \\
\text { Energy } \\
\text { Partners }\end{array}$} & & $\begin{array}{l}\text { Forestport } \\
(\mathrm{P}-4900)\end{array}$ & Owner/Operator & $\begin{array}{l}\text { Independent } \\
\text { Power } \\
\text { Producer }\end{array}$ & 29 & $\begin{array}{l}\text { National and } \\
\text { International }\end{array}$ \\
\hline & & $\begin{array}{l}\text { Kayuta Lake } \\
(P-5000)\end{array}$ & & & & \\
\hline $\begin{array}{l}\text { EONY } \\
\text { Generation } \\
\text { Limited }\end{array}$ & $\begin{array}{l}\text { Hydro Ottawa } \\
\text { Holding Inc. }\end{array}$ & $\begin{array}{l}\text { Moose River } \\
(\mathrm{P}-4349)\end{array}$ & Owner/Operator & $\begin{array}{l}\text { Electric Utility } \\
\text { Holding } \\
\text { Company }\end{array}$ & 47 & $\begin{array}{l}\text { National and } \\
\text { International }\end{array}$ \\
\hline $\begin{array}{l}\text { Northbrook } \\
\text { Lyons Falls }\end{array}$ & $\begin{array}{l}\text { Lyons Falls } \\
\text { Kruger Inc. }\end{array}$ & $\begin{array}{l}\text { Lyons Falls } \\
\text { (P-2458) }\end{array}$ & Owner/Operator & Manufacturer & 545 & $\begin{array}{l}\text { National and } \\
\text { International }\end{array}$ \\
\hline $\begin{array}{l}\text { Lyonsdale } \\
\text { Associates }\end{array}$ & $\begin{array}{l}\text { Cube } \\
\text { Hydro } \\
\text { Partners, } \\
\text { LLC }\end{array}$ & $\begin{array}{l}\text { Lyonsdale } \\
\text { (P-3255) }\end{array}$ & Owner/Operator & $\begin{array}{l}\text { Independent } \\
\text { Power } \\
\text { Producer }\end{array}$ & 372 & National \\
\hline
\end{tabular}

Sources: Ampersand Energy 2018; Brookfield Energy 2017; Lyons Falls Hydropower 2018; Cube Hydro 2018; Hydro Ottawa Holding Inc. 2017

\subsubsection{Advantages}

Potential advantages associated with New York's basin-wide approach to hydropower relicensing include:

- Extended license terms for Lyonsdale and Kayuta

- Early communication and coordination with stakeholders

- Federal agency (including FERC), state agency, and stakeholder support

- Federal and state agencies conducted site visit of all projects within the basin to better understand the water uses and the overall demands on the ecology of the river

- Federal and state agency-initiated basin-wide study protocol to utilize for all projects within the basin

- Consistency in study plan development across projects within the basin

- Consistency in administration of studies for projects within the basin

\footnotetext{
22 Total capacity owned includes all hydroelectric assets, nationally and internationally owned by the licensee parent company (if applicable) and is an approximation acquired from FERC, the licensee, and public documents.
} 
- Coordination and consistency of prescribed terms and conditions among projects

- Coordinated use of the ALP by all licensees

- Coordinated preparation of a joint PAD for all licensees to file

- Coordinated FERC filings

- Coordinated consultation

- Coordinated studies and preparation of joint study report

- Reduced cost associated with the relicensing process

- Settlement agreement among licensees and stakeholders

- Offsets from external funding sources (e.g., grants)

(Jessica Hart, New York State Department of Environmental Conservation Region 6, and John Wiley, U.S. Fish and Wildlife Service, telephone conference, August 7, 2018; Sayad Moudachirou, Ampersand Energy Partners, LLC, telephone conference, August 6, 2018; David Fox, Cube Hydro Partners, LLC, telephone conference, August 6, 2018).

\subsubsection{Challenges}

Potential challenges associated with New York's basin-wide approach to hydropower relicensing include:

- Pioneering a comprehensive approach to relicensing - it has never been done before

- Initiated by federal and state agencies which have multiple resource demands and constraints

- Licensee buy-in

- Some projects have existing settlement agreements in place, others do not

- Licensees have diverse interests and backgrounds

- Licensees have differing levels of experience in the relicensing process

- Licensees have differing levels of resources available

- Studies will likely extend beyond FERC license boundaries of individual projects

- Conflict when negotiating the terms and conditions of the license - a term or a condition for one project may be at the detriment of another project

- Equity of the relicensing process - larger licensees dictating the relicensing process for smaller licensees, smaller licensees utilizing the resources of the larger licensees

(Jessica Hart, New York State Department of Environmental Conservation Region 6, and John Wiley, U.S. Fish and Wildlife Service, telephone conference, August 7, 2018; Sayad Moudachirou, Ampersand Energy Partners, LLC, telephone conference, August 6, 2018; Steven Murphy, Brookfield Renewable Energy Partners LLC, telephone conference, August 16, 2018; David Fox, Cube Hydro Partners, LLC, telephone conference, August 6, 2018).

\subsubsection{Wisconsin River Basin-Wide Relicensing Proposal}

In Wisconsin, licensees and regulators are working together to pioneer one of the nation's first comprehensive basin-wide approaches to hydropower relicensing. Recognizing the number of FERC-licensed projects in the Wisconsin River Basin due to expire in the coming years, the licensees came together to devise a strategy to relicense these projects in an efficient manner. As a result, nine licensees have proposed a basin-wide approach to coordinate the relicense of 20 Wisconsin River projects in three stages according to the project's location. The proposal 
suggests grouping projects into one of three sub-basins (i.e., the North Wisconsin Basin, the Central Wisconsin Basin, and the South Wisconsin Basin) and staggering the relicensing timelines.

\subsubsection{Hydropower Relicensing in Wisconsin}

Wisconsin has a total of 70 FERC-licensed hydropower projects, with a total combined generating capacity of $457 \mathrm{MW}$, with license expiration dates from 2018-2037 (FERC 2017a). Of those projects, 21 have license expiration dates that require filing an NOI and a PAD for a new license with FERC in 2032 (FERC 2017a). The highest volume of hydropower projects in Wisconsin due to expire in the coming years are on the Wisconsin River. ${ }^{23}$

\section{Wisconsin River Basin}

The Wisconsin River Basin ${ }^{24}$ includes 20 hydropower projects (41 total developments) that are scheduled to undergo relicensing between 2026 and 2035 (FERC 2017a). Of those 20 projects, 12 currently have a license expiration date in 2026 (FERC 2017a). Figure 8 illustrates the hydropower projects within the Wisconsin River Basin with license expiration dates between 2026 and 2035.

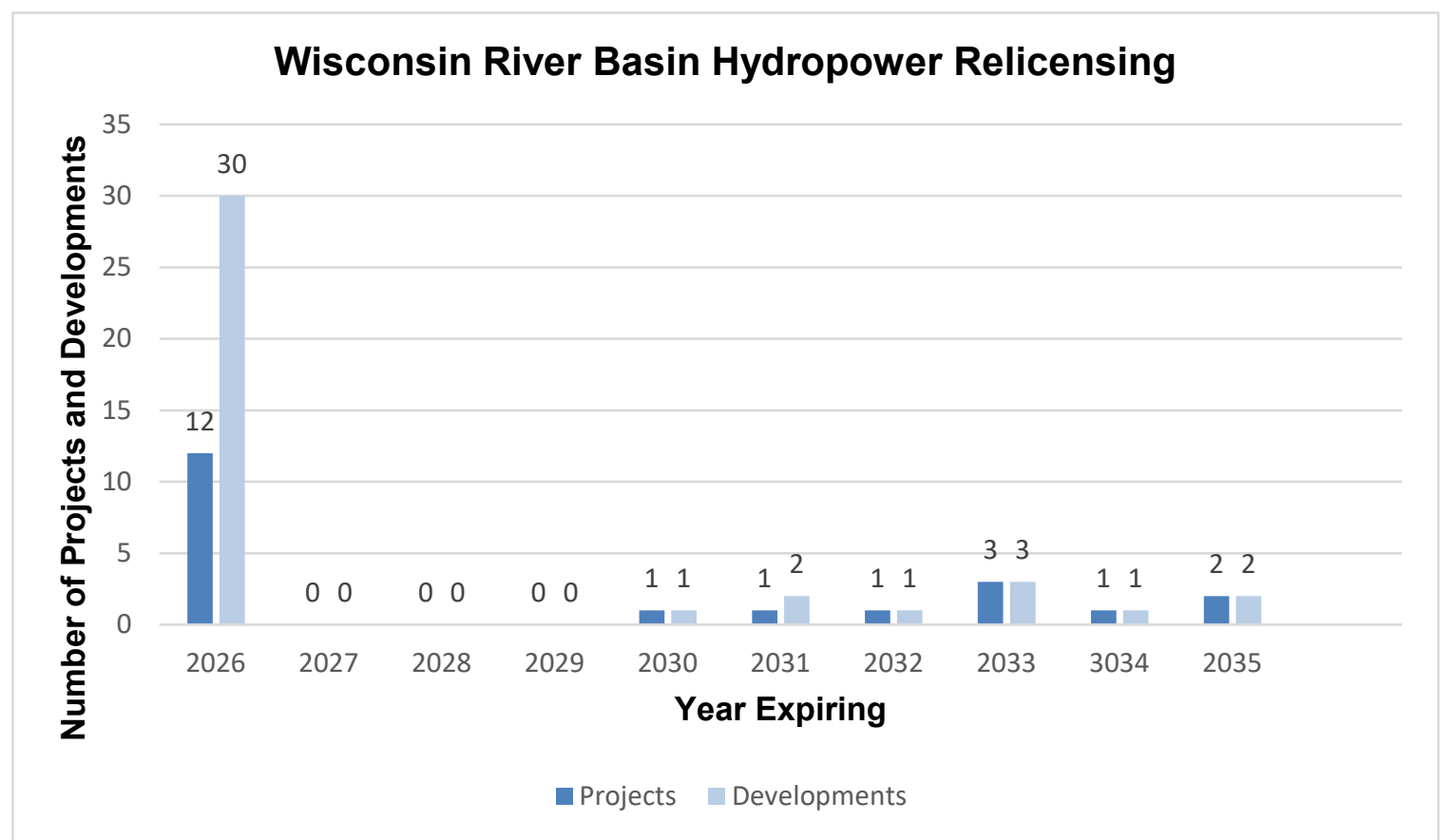

Figure 9. Wisconsin River Basin hydropower relicensing workload-projects and developments

\footnotetext{
${ }^{23}$ The Wisconsin River is the largest river in Wisconsin and stretches 430 miles from Lac Vieux Desert on the Wisconsin-Michigan boundary in the north to Prairie due Chien in southwestern Wisconsin, where it empties into the Mississippi River (WVIC 2018a). The Wisconsin River is divided into three sub-basins - the northern, central, and southern Wisconsin River basins (WDNR 2018a).

${ }^{24}$ The Wisconsin River Basin as a whole encompasses $20 \%$ of the state, extending from the forest region of northeast Wisconsin through the vegetation tension zone of central Wisconsin to the prairie areas of southern Wisconsin, including 11,800 square miles (WPSC 2018; U.S. Geological Survey 1917). The largest tributary to the Wisconsin River in terms of water flow is the Tomahawk River (WDNR 2018b).
} 


\subsubsection{Implementation History and Process}

Starting in April 2018, licensees began to submit requests for comment on a proposal to align the relicensing timelines of 20 separately FERC-licensed hydropower projects on the Wisconsin River and to extend the license terms of their respective projects (WRPC 2018). The licensees submitted individual requests to the Wisconsin Department of Natural Resources (WDNR), USFWS, the National Park Service, and other stakeholders with regard to their projects (Cheryl Laatsch, Wisconsin Department of Natural Resources, telephone conference, August 7, 2018). The licensees requested comments on the coordinated relicensing effort and the license term extensions within 60 days (Cheryl Laatsch, Wisconsin Department of Natural Resources, telephone conference, August 7, 2018).

WDNR requested additional information on the rationale behind the proposed extension requests and asked the licensees to provide a stakeholder list for each project. In addition, WDNR requested that each licensee determine whether they foresaw "any complex or potentially controversial issues" related to the relicense of their project (WDNR 2018c). After the comment period expires, the licensees intend to submit a non-capacity license amendment request to FERC requesting a license term extension for their projects (Domtar 2018; WRPCO 2018).

In total, 9 licensees of 20 separately licensed hydropower projects within the Wisconsin River Basin propose to coordinate the relicensing timelines of the projects within the basin. The licensees "coordinated extensively regarding the need to align their future license expiration" (Domtar 2018). Originally, the licensees considered requesting a single expiration date for all 20 projects within the basin that are scheduled to expire from 2026-2035 (Domtar 2018; WRPCO 2018). However, the licensees recognized that relicensing that many projects at the same time could put strain on the federal and state agencies and other stakeholders (Domtar 2018; WRPCO 2018). In addition, the licensees found that "administering a single expiration date for all projects...would be impractical given the breadth..." of the river basin (Domtar 2018; WRPCO 2018). Instead, the licensees propose to coordinate the relicense of the projects in three stagesgrouping projects into one of three sub-basins and staggering the relicensing timelines (Domtar 2018; WRPCO 2018).

Table 5 identifies the licensees and their corresponding hydropower projects within the Wisconsin River Basin that have proposed to coordinate relicensing efforts. 
Table 5. Wisconsin River Basin Proposal: Projects

\begin{tabular}{|c|c|c|c|c|c|}
\hline Project Name & Licensee & Waterway & $\begin{array}{l}\text { Basin } \\
\text { Location }\end{array}$ & $\begin{array}{l}\text { License } \\
\text { Issuance } \\
\text { Date }\end{array}$ & $\begin{array}{l}\text { License } \\
\text { Expiration } \\
\text { Date }\end{array}$ \\
\hline $\begin{array}{l}\text { Wisconsin Valley } \\
\text { Reservoirs } \\
\text { (P-2113) }\end{array}$ & $\begin{array}{l}\text { Wisconsin Valley } \\
\text { Improvement Co. }\end{array}$ & $\begin{array}{l}\text { Wisconsin River } \\
\text { \& Headwater } \\
\text { Tributary }\end{array}$ & North & 07/18/1996 & $06 / 30 / 2026$ \\
\hline $\begin{array}{l}\text { Otter Rapids } \\
\text { (P-1957) }\end{array}$ & $\begin{array}{l}\text { Wisconsin Public } \\
\text { Service Corp. } \\
\text { (WPSC) }\end{array}$ & Wisconsin River & North & 10/24/1989 & $06 / 30 / 2030$ \\
\hline $\begin{array}{l}\text { Rhinelander } \\
\text { (P-2161) }\end{array}$ & $\begin{array}{l}\text { Expera Specialty } \\
\text { Solutions }\end{array}$ & Wisconsin River & North & 08/13/2003 & $07 / 31 / 2033$ \\
\hline $\begin{array}{l}\text { Kings Dam } \\
\text { (P-2239) }\end{array}$ & $\begin{array}{l}\text { Tomahawk } \\
\text { Power \& Pulp Co. }\end{array}$ & Wisconsin River & North & 07/18/1996 & $06 / 30 / 2026$ \\
\hline $\begin{array}{l}\text { Jersey } \\
\text { (P-2476) }\end{array}$ & WPSC & $\begin{array}{l}\text { Tomahawk } \\
\text { River }\end{array}$ & North & 07/18/1996 & $06 / 30 / 2026$ \\
\hline $\begin{array}{l}\text { Grandmother } \\
(P-2180)\end{array}$ & PCA Hydro Inc. & Wisconsin River & North & 01/06/2005 & $12 / 31 / 2034$ \\
\hline $\begin{array}{l}\text { Alexander } \\
(\mathrm{P}-1979)\end{array}$ & WPSC & Wisconsin River & North & 03/04/2005 & $02 / 28 / 2035$ \\
\hline $\begin{array}{l}\text { Wausau } \\
(P-1999)\end{array}$ & WPSC & Wisconsin River & North & 07/18/1996 & $06 / 30 / 2026$ \\
\hline $\begin{array}{l}\text { Rothchild } \\
\text { (P-2212) }\end{array}$ & $\begin{array}{l}\text { Domtar Paper } \\
\text { Company, LLC. }\end{array}$ & Wisconsin River & Central & 07/18/1996 & $06 / 30 / 2026$ \\
\hline $\begin{array}{l}\text { Mosinee } \\
(P-2207)\end{array}$ & $\begin{array}{l}\text { Expera Specialty } \\
\text { Solutions }\end{array}$ & Wisconsin River & Central & 04/07/2005 & $03 / 31 / 2035$ \\
\hline $\begin{array}{l}\text { DuBay } \\
\text { (P-1953) }\end{array}$ & $\begin{array}{l}\text { Consolidated } \\
\text { Water Power Co. }\end{array}$ & Wisconsin River & Central & 10/24/1991 & $06 / 30 / 2026$ \\
\hline $\begin{array}{l}\text { Stevens Point } \\
(P-2110)\end{array}$ & $\begin{array}{l}\text { Consolidated } \\
\text { Water Power Co. }\end{array}$ & Wisconsin River & Central & 07/30/2003 & $06 / 30 / 2033$ \\
\hline $\begin{array}{l}\text { Whiting } \\
(P-2590)\end{array}$ & $\begin{array}{l}\text { Consolidated } \\
\text { Water Power Co. }\end{array}$ & Wisconsin River & Central & 07/18/1996 & $06 / 30 / 2026$ \\
\hline $\begin{array}{l}\text { Biron } \\
(\mathrm{P}-2192)\end{array}$ & $\begin{array}{l}\text { Consolidated } \\
\text { Water Power Co. }\end{array}$ & Wisconsin River & Central & 07/30/2003 & $06 / 30 / 2033$ \\
\hline $\begin{array}{l}\text { Wisconsin } \\
\text { Rapids } \\
\text { (P-2256) }\end{array}$ & $\begin{array}{l}\text { Consolidated } \\
\text { Water Power Co. }\end{array}$ & Wisconsin River & Central & 07/18/1996 & $06 / 30 / 2036$ \\
\hline
\end{tabular}




\begin{tabular}{llllll}
\hline Project Name & Licensee & Waterway & $\begin{array}{l}\text { Basin } \\
\text { Location }\end{array}$ & $\begin{array}{l}\text { License } \\
\text { Issuance } \\
\text { Date }\end{array}$ & $\begin{array}{l}\text { License } \\
\text { Expiration } \\
\text { Date }\end{array}$ \\
\hline $\begin{array}{l}\text { Centralia } \\
\text { (P-2255) }\end{array}$ & $\begin{array}{l}\text { Domtar } \\
\text { Wisconsin Corp. }\end{array}$ & Wisconsin River & Central & $07 / 18 / 1996$ & $06 / 30 / 2026$ \\
$\begin{array}{l}\text { Port Edwards } \\
\text { (P-2291) }\end{array}$ & $\begin{array}{l}\text { Domtar } \\
\text { Wisconsin Corp. }\end{array}$ & Wisconsin River & Central & $07 / 18 / 1996$ & $06 / 30 / 2026$ \\
$\begin{array}{l}\text { Nekoosa } \\
\text { (P-2292) }\end{array}$ & $\begin{array}{l}\text { Domtar } \\
\text { Wisconsin Corp. }\end{array}$ & Wisconsin River & Central & $07 / 18 / 1996$ & $06 / 30 / 2026$ \\
\hline $\begin{array}{l}\text { Petenwell and } \\
\text { Castle Rock } \\
\text { (P-1984) }\end{array}$ & $\begin{array}{l}\text { Wisconsin River } \\
\text { Power Co. }\end{array}$ & Wisconsin River & South & $12 / 07 / 2001$ & $11 / 30 / 2031$ \\
$\begin{array}{l}\text { Prairie Du Sac } \\
\text { (P-11162) }\end{array}$ & $\begin{array}{l}\text { Wisconsin River } \\
\text { Power Co. }\end{array}$ & Wisconsin River & South & $06 / 27 / 2002$ & $05 / 31 / 2032$ \\
\hline
\end{tabular}

Source: FERC 2017a; WRPC 2018; WVIC 2018

\subsubsection{Proposal Details}

The proposal supports subdividing the Wisconsin River Basin into three sub-basins: the Northern Basin, the Central Basin, and the Southern Basin. The licensees suggest grouping projects into one of the three sub-basins and staggering the relicensing timelines for the 20 projects with license term expiration dates between 2026 and 2035 (WPSC 2018; WRPC 2018). The proposal requires a license term extension for each hydropower project. Eight hydropower projects within the Northern Basin would be extended to June 30, 2035, 10 projects within the Central Basin would be extended to June 30, 2038, and the remaining projects within the Southern Basin would be extended to June 30, 2041 (WPSC 2018; WRPC 2018).

Consideration: "Dividing the Wisconsin River into three sub-basins with staggered license expiration dates will allow for comprehensive studies and analysis of the projects, expedite the consultation process for all parties, and maximize the consideration of cumulative environmental impacts while minimizing the resource strain associated with having too many projects being relicensed at the same time" (WRPC 2018; WPSC 2018). 


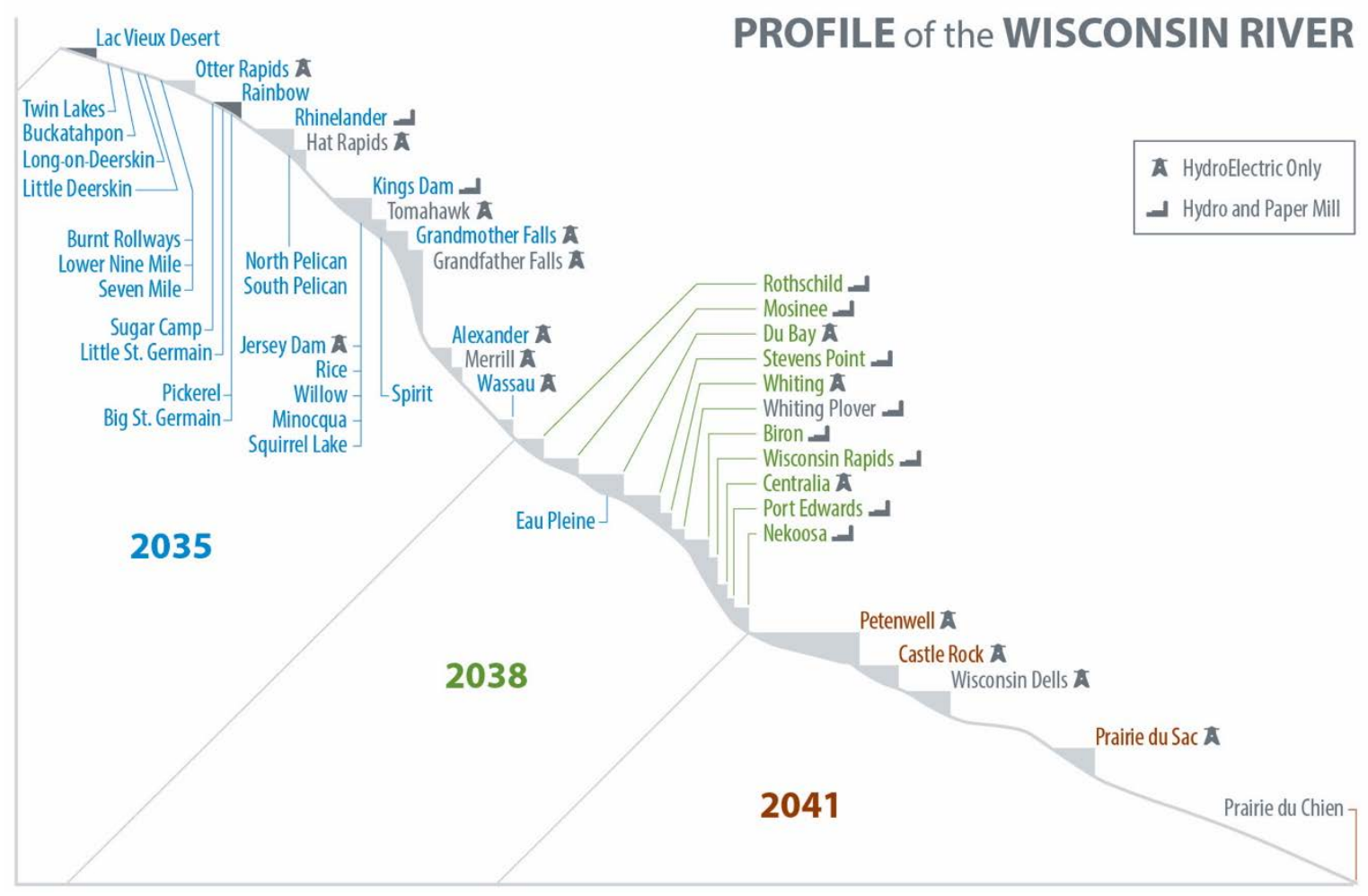

Figure 10. Wisconsin River Basin proposal: map of hydropower projects

The Wisconsin River stretches approximately 430 miles from Lac Vieux Desert on the northern Wisconsin-Michigan border to the Prairie due Chien in southwestern Wisconsin (WVIC 2018a). "The vegetation, hydrologic and natural resource concerns" from northern Wisconsin through the "vegetation tension zone of central Wisconsin to the prairie areas of southern Wisconsin" are very different (WPSC 2018; WRPC 2018). The basin-wide relicensing proposal attempts to group projects within the same geographic area that have similar vegetation, land cover, hydrology, and resource management concerns (WPSC 2018; WRPC 2018).

Consideration: River basins are geographically vast and are often diverse with varying vegetation, hydrologic, environmental, and natural resource concerns from one segment of the river basin to another. The variations in the surrounding topography and flow of a river basin can influence historical, cultural, recreational, and other activities.

The Northern Basin is dominated by forest landscape and wetlands (WDNR 2002). This portion of the basin includes 20 storage reservoirs ${ }^{25}$ managed by Wisconsin Valley Improvement Co. to increase river flows. Five licensees with a total of eight hydropower projects are located in the Northern Basin, which could allow coordinated operations and management (WPSC 2018; WRPC 2018).

${ }^{25}$ Wisconsin Valley Improvement Co. has one additional storage reservoir as part of the FERC-licensed Wisconsin Valley Reservoirs Project (P-2113), which is located in the Central Wisconsin River Basin. 
The Central Basin incorporates portions of the vegetation tension zone "where vegetation transitions from northern forest to southern forests and prairies" (WPSC 2018; WRPC 2018). The landscape in this portion of the basin is defined by agriculture and industry (WDNR 2002). In comparison to the Northern Basin, the amount of "woodland decreases and the human population density increases" (WPSC 2018; WRPC 2018). Several large tributaries including the Little Eau Pleine River and the Lower Yellow River enter the Central Basin, which impact the landscape and hydrological and ecological conditions as compared to the Northern Basin (WPSC 2018; WRPC 2018; WDNR 2018). Three licensees with a total of 10 projects are located in the Central Basin, which could allow coordinated operations and management (WPSC 2018; WRPC 2018).

In contrast, the Southern Basin landscape is dominated by agriculture and prairie lands (WPSC 2018; WRPC 2018). The Southern Basin drains approximately 4,940 square miles of south central and southwestern Wisconsin (WDNR 2018b). Several large tributaries, including Beaver Creek and the Middle Kickapoo River, enter the Southern Basin. The large tributaries and the culmination of flows from upstream "form large reservoirs which have different hydrologic and resource management concerns than projects in the Central Basin" (WPSC 2018; WRPC 2018).

\section{Aligning License Expiration Dates}

The proposed basin-wide approach calls for a license term extension for all 20 hydropower projects. Table 6 details the proposed license term extensions for each hydropower project. The eight hydropower projects in the North Wisconsin River Basin propose license term extensions to June 30,2026. The longest license term extension proposed for the projects in the North Wisconsin River Basin is 9 years, and the average license term extension proposed for the projects is approximately 5.5 years.

The 10 hydropower projects in the Central Wisconsin River Basin propose license term extensions to June 30,2035. The longest license term extension proposed for the projects in the Central Wisconsin River Basin is 12 years, and the average license term extension proposed for the projects is approximately 10 years. The two hydropower projects in the South Wisconsin River Basin propose license term extensions to June 30, 2041. The Petenwell and Castle Rock Project in the South Wisconsin Basin proposes a 9.5-year license term extension while the proposal for the Prairie Du Sac Project is 9 years and 1 month. 
Table 6. Wisconsin River Basin Proposal: License Expiration Date Alignment

\begin{tabular}{|c|c|c|c|c|c|}
\hline Project Name & Licensee & $\begin{array}{l}\text { Basin } \\
\text { Location }\end{array}$ & $\begin{array}{l}\text { Current } \\
\text { License } \\
\text { Expiration } \\
\text { Date }\end{array}$ & $\begin{array}{l}\text { Proposed } \\
\text { License } \\
\text { Expiration } \\
\text { Date }\end{array}$ & $\begin{array}{l}\text { Proposed } \\
\text { Extension of } \\
\text { License }\end{array}$ \\
\hline $\begin{array}{l}\text { Wisconsin Valley } \\
\text { Reservoirs } \\
(\mathrm{P}-2113)\end{array}$ & $\begin{array}{l}\text { Wisconsin Valley } \\
\text { Improvement Co. }\end{array}$ & North & 06/30/2026 & 06/30/2035 & 9 Years \\
\hline $\begin{array}{l}\text { Otter Rapids } \\
(\mathrm{P}-1957)\end{array}$ & WPSC & North & 06/30/2030 & 06/30/2035 & 5 Years \\
\hline $\begin{array}{l}\text { Rhinelander } \\
\text { (P-2161) }\end{array}$ & $\begin{array}{l}\text { Expera Specialty } \\
\text { Solutions }\end{array}$ & North & 07/31/2033 & 06/30/2035 & $\begin{array}{l}1 \text { Year } 11 \\
\text { Months }\end{array}$ \\
\hline $\begin{array}{l}\text { Kings Dam } \\
\text { (P-2239) }\end{array}$ & $\begin{array}{l}\text { Tomahawk Power \& } \\
\text { Pulp Co. }\end{array}$ & North & 06/30/2026 & 06/30/2035 & 9 Years \\
\hline $\begin{array}{l}\text { Jersey } \\
(P-2476)\end{array}$ & WPSC & North & 06/30/2026 & 06/30/2035 & 9 Years \\
\hline $\begin{array}{l}\text { Grandmother } \\
(\mathrm{P}-2180)\end{array}$ & PCA Hydro Inc. & North & $12 / 31 / 2034$ & 06/30/2035 & 6 Months \\
\hline $\begin{array}{l}\text { Alexander } \\
(\mathrm{P}-1979)\end{array}$ & WPSC & North & 02/28/2035 & 06/30/2035 & 4 Months \\
\hline $\begin{array}{l}\text { Wausau } \\
(P-1999)\end{array}$ & WPSC & North & 06/30/2026 & 06/30/2035 & 9 Years \\
\hline $\begin{array}{l}\text { Rothchild } \\
\text { (P-2212) }\end{array}$ & $\begin{array}{l}\text { Domtar Paper } \\
\text { Company, LLC. }\end{array}$ & Central & 06/30/2026 & 06/30/2038 & 12 Years \\
\hline $\begin{array}{l}\text { Mosinee } \\
(\mathrm{P}-2207)\end{array}$ & $\begin{array}{l}\text { Expera Specialty } \\
\text { Solutions }\end{array}$ & Central & 03/31/2035 & 06/30/2038 & $\begin{array}{l}3 \text { Years } 3 \\
\text { Months }\end{array}$ \\
\hline $\begin{array}{l}\text { DuBay } \\
\text { (P-1953) }\end{array}$ & $\begin{array}{l}\text { Consolidated Water } \\
\text { Power Co. }\end{array}$ & Central & 06/30/2026 & 06/30/2038 & 12 Years \\
\hline $\begin{array}{l}\text { Stevens Point } \\
(P-2110)\end{array}$ & $\begin{array}{l}\text { Consolidated Water } \\
\text { Power Co. }\end{array}$ & Central & 06/30/2033 & 06/30/2038 & 5 Years \\
\hline $\begin{array}{l}\text { Whiting } \\
(\mathrm{P}-2590)\end{array}$ & $\begin{array}{l}\text { Consolidated Water } \\
\text { Power Co. }\end{array}$ & Central & 06/30/2026 & 06/30/2038 & 12 Years \\
\hline $\begin{array}{l}\text { Biron } \\
(\mathrm{P}-2192)\end{array}$ & $\begin{array}{l}\text { Consolidated Water } \\
\text { Power Co. }\end{array}$ & Central & 06/30/2033 & 06/30/2038 & 5 Years \\
\hline $\begin{array}{l}\text { Wisconsin } \\
\text { Rapids } \\
\text { (P-2256) }\end{array}$ & $\begin{array}{l}\text { Consolidated Water } \\
\text { Power Co. }\end{array}$ & Central & 06/30/2038 & 06/30/2038 & 12 Years \\
\hline
\end{tabular}




\begin{tabular}{|c|c|c|c|c|c|}
\hline Project Name & Licensee & $\begin{array}{l}\text { Basin } \\
\text { Location }\end{array}$ & $\begin{array}{l}\text { Current } \\
\text { License } \\
\text { Expiration } \\
\text { Date }\end{array}$ & $\begin{array}{l}\text { Proposed } \\
\text { License } \\
\text { Expiration } \\
\text { Date } \\
\end{array}$ & $\begin{array}{l}\text { Proposed } \\
\text { Extension of } \\
\text { License }\end{array}$ \\
\hline $\begin{array}{l}\text { Centralia } \\
(\mathrm{P}-2255)\end{array}$ & $\begin{array}{l}\text { Domtar Wisconsin } \\
\text { Corp. }\end{array}$ & Central & 06/30/2026 & $06 / 30 / 2038$ & 12 Years \\
\hline $\begin{array}{l}\text { Port Edwards } \\
\text { (P-2291) }\end{array}$ & $\begin{array}{l}\text { Domtar Wisconsin } \\
\text { Corp. }\end{array}$ & Central & 06/30/2026 & $06 / 30 / 2038$ & 12 Years \\
\hline $\begin{array}{l}\text { Nekoosa } \\
(\mathrm{P}-2292)\end{array}$ & $\begin{array}{l}\text { Domtar Wisconsin } \\
\text { Corp. }\end{array}$ & Central & 06/30/2026 & $06 / 30 / 2038$ & 12 Years \\
\hline $\begin{array}{l}\text { Petenwell and } \\
\text { Castle Rock } \\
\text { (P-1984) }\end{array}$ & $\begin{array}{l}\text { Wisconsin River } \\
\text { Power Co. }\end{array}$ & South & $11 / 30 / 2031$ & $06 / 30 / 2041$ & $\begin{array}{l}9 \text { Years } 5 \\
\text { Months }\end{array}$ \\
\hline $\begin{array}{l}\text { Prairie Du Sac } \\
(\mathrm{P}-11162)\end{array}$ & $\begin{array}{l}\text { Wisconsin River } \\
\text { Power Co. }\end{array}$ & South & 05/31/2032 & $06 / 30 / 2041$ & $\begin{array}{l}9 \text { Years } 1 \\
\text { Month }\end{array}$ \\
\hline
\end{tabular}

Source: FERC 2017a; WRPC 2018

\subsubsection{Project and Licensee Characteristics}

This section identifies the similarities and differences of the hydropower projects and licensees within the Wisconsin River Basin proposing to coordinate relicensing efforts.

\section{Project Characteristics}

The 20 hydropower projects located within the Wisconsin River Basin vary in size, annual production, basin location, and operating mode. Table 7 highlights some of the characteristics of each hydropower project that may participate in the basin-wide relicensing proposal.

Table 7. Wisconsin River Basin Proposal: Project Characteristics

\begin{tabular}{llclll}
\hline Project Name & $\begin{array}{l}\text { Operating } \\
\text { Mode }\end{array}$ & $\begin{array}{l}\text { Number of } \\
\text { Developments }\end{array}$ & $\begin{array}{l}\text { Generation } \\
\text { Capacity } \\
\text { (MW) }\end{array}$ & $\begin{array}{l}\text { Annual } \\
\text { Production } \\
\text { (MWH) }\end{array}$ & $\begin{array}{l}\text { Basin } \\
\text { Location }\end{array}$ \\
\hline $\begin{array}{l}\text { Wisconsin Valley Reservoirs } \\
\text { (P-2113) }\end{array}$ & Storage & 21 & 0 & 0 & North \\
\hline $\begin{array}{l}\text { Otter Rapids } \\
\text { (P-1957) }\end{array}$ & Run-of-River & 1 & 0.70 & 2,432 & North \\
\hline $\begin{array}{l}\text { Rhinelander } \\
\text { (P-2161) }\end{array}$ & Run-of-River & 1 & 2.12 & 10,728 & North \\
\hline $\begin{array}{l}\text { Kings Dam } \\
\text { (P-2239) }\end{array}$ & Storage and & 1 & 2.51 & 10,433 & North \\
$\begin{array}{l}\text { Jersey } \\
\text { (P-2476) }\end{array}$ & Release & 1 & 0.51 & 3,011 & North \\
\hline
\end{tabular}

${ }^{26}$ Generation capacity is the authorized generation capacity per FERC record. 


\begin{tabular}{|c|c|c|c|c|c|}
\hline Project Name & $\begin{array}{l}\text { Operating } \\
\text { Mode }\end{array}$ & $\begin{array}{l}\text { Number of } \\
\text { Developments }\end{array}$ & $\begin{array}{l}\text { Generation } \\
\text { Capacity } \\
(\mathbf{M W})^{26}\end{array}$ & $\begin{array}{l}\text { Annual } \\
\text { Production } \\
\text { (MWH) }\end{array}$ & $\begin{array}{l}\text { Basin } \\
\text { Location }\end{array}$ \\
\hline $\begin{array}{l}\text { Grandmother } \\
\text { (P-2180) }\end{array}$ & Run-of-River & 1 & 3.00 & 17,909 & North \\
\hline $\begin{array}{l}\text { Alexander } \\
\text { (P-1979) }\end{array}$ & $\begin{array}{l}\text { Limited } \\
\text { Peaking/Run-of- } \\
\text { River }\end{array}$ & 1 & 4.20 & 24,103 & North \\
\hline $\begin{array}{l}\text { Wausau } \\
(P-1999)\end{array}$ & Run-of-River & 1 & 5.40 & 32,375 & North \\
\hline $\begin{array}{l}\text { Rothchild } \\
\text { (P-2212) }\end{array}$ & Run-of-River & 1 & 3.71 & 22,736 & Central \\
\hline $\begin{array}{l}\text { Mosinee } \\
(\mathrm{P}-2207)\end{array}$ & Run-of-River & 1 & 3.05 & 23,865 & Central \\
\hline $\begin{array}{l}\text { DuBay } \\
\text { (P-1953) }\end{array}$ & Run-of-River & 1 & 7.20 & 43,278 & Central \\
\hline $\begin{array}{l}\text { Stevens Point } \\
(\mathrm{P}-2110)\end{array}$ & Run-of-River & 1 & 3.84 & 28,184 & Central \\
\hline $\begin{array}{l}\text { Whiting } \\
\text { (P-2590) }\end{array}$ & Run-of-River & 1 & 6.37 & 40,343 & Central \\
\hline $\begin{array}{l}\text { Biron } \\
\text { (P-2192) }\end{array}$ & Run-of-River & 1 & 6.23 & 36,497 & Central \\
\hline $\begin{array}{l}\text { Wisconsin Rapids } \\
\text { (P-2256) }\end{array}$ & Run-of-River & 1 & 9.23 & 54,493 & Central \\
\hline $\begin{array}{l}\text { Centralia } \\
(P-2255)\end{array}$ & $\begin{array}{l}\text { Micro/Run-of- } \\
\text { River }\end{array}$ & 1 & 3.32 & 23,492 & Central \\
\hline $\begin{array}{l}\text { Port Edwards } \\
\text { (P-2291) }\end{array}$ & $\begin{array}{l}\text { Micro/Run-of- } \\
\text { River }\end{array}$ & 1 & 3.53 & 17,863 & Central \\
\hline $\begin{array}{l}\text { Nekoosa } \\
\text { (P-2292) }\end{array}$ & $\begin{array}{l}\text { Micro/Run-of- } \\
\text { River }\end{array}$ & 1 & 3.53 & 26,450 & Central \\
\hline $\begin{array}{l}\text { Petenwell and Castle } \\
\text { Rock } \\
\text { (P-1984) }\end{array}$ & $\begin{array}{l}\text { Peaking/Run- } \\
\text { of-River }\end{array}$ & 2 & 35.00 & 194,756 & South \\
\hline $\begin{array}{l}\text { Prairie Du Sac } \\
(P-11162)\end{array}$ & Run-of-River & 1 & 27.3 & 135,012 & South \\
\hline
\end{tabular}

Source: FERC 2017a; WVIC 2018a; WVIC 2018 


\section{Licensee Characteristics}

The nine licensees of the projects that may participate in the basin-wide hydropower relicensing proposal vary in company size and type. The majority of the licensees are either a Wisconsin public utility or a manufacturer (paper mill). The WPSC is the largest company in terms of total hydropower assets - owning and operating 15 hydropower projects with a total combined generation capacity of $97.2 \mathrm{MW}$. Table 8 highlights some of the licensee characteristics of each hydropower project that may participate in the basin-wide relicensing pilot.

Table 8. Wisconsin River Basin Proposal: Licensee Characteristics

\begin{tabular}{|c|c|c|c|c|c|}
\hline Licensee & Projects & $\begin{array}{l}\text { Ownerl } \\
\text { Operator }\end{array}$ & Licensee Type & $\begin{array}{l}\text { Total Capacity } \\
\text { Owned (MW) }\end{array}$ & $\begin{array}{l}\text { Asset } \\
\text { Location }\end{array}$ \\
\hline $\begin{array}{l}\text { Wisconsin } \\
\text { Valley } \\
\text { Improvement } \\
\text { Co. }\end{array}$ & $\begin{array}{l}\text { Wisconsin } \\
\text { Valley } \\
\text { Reservoirs } \\
(P-2113)\end{array}$ & Operator & $\begin{array}{l}\text { Regulated } \\
\text { Entity } 28\end{array}$ & 0 & Wisconsin \\
\hline WPSC & $\begin{array}{l}\text { Otter Rapids } \\
\text { (P-1957) } \\
\text { Jersey } \\
\text { (P-2476) } \\
\text { Alexander } \\
\text { (P-1979) } \\
\text { Wausau } \\
\text { (P-1999) }\end{array}$ & $\begin{array}{l}\text { Owner/ } \\
\text { Operator }\end{array}$ & Public Utility & $97^{29}$ & National \\
\hline $\begin{array}{l}\text { Expera } \\
\text { Specialty } \\
\text { Solutions }\end{array}$ & $\begin{array}{l}\text { Rhinelander } \\
\text { (P-2161) } \\
\text { Mosinee } \\
\text { (P-2207) }\end{array}$ & $\begin{array}{l}\text { Owner/ } \\
\text { Operator }\end{array}$ & $\begin{array}{l}\text { Manufacturer - } \\
\text { Paper Mill }\end{array}$ & 5 & Wisconsin \\
\hline $\begin{array}{l}\text { Tomahawk } \\
\text { Power and Pulp } \\
\text { Co. }\end{array}$ & $\begin{array}{l}\text { Kings Dam } \\
\text { (P-2239) }\end{array}$ & $\begin{array}{l}\text { Owner/ } \\
\text { Operator }\end{array}$ & $\begin{array}{l}\text { Independent } \\
\text { Power } \\
\text { Producer }\end{array}$ & 3 & Wisconsin \\
\hline $\begin{array}{l}\text { PCA Hydro } \\
\text { Inc. }\end{array}$ & $\begin{array}{l}\text { Grandmother } \\
(P-2180)\end{array}$ & Unknown & $\begin{array}{l}\text { Independent } \\
\text { Power } \\
\text { Producer }\end{array}$ & Unknown & Wisconsin \\
\hline
\end{tabular}

\footnotetext{
${ }^{27}$ Total capacity owned includes all hydroelectric assets, nationally and internationally owned by the licensee, parent company (if applicable), and is an approximation acquired from FERC and public documents.

${ }^{28}$ The Wisconsin Valley Improvement Company is a private company created by Wisconsin statute in 1907 to maintain the Wisconsin River's flow for hydropower generation. Various operators who generate hydropower in the Wisconsin River Basin own the company's stock, which supports the company's operating costs (Wisconsin Valley Improvement Company, 76 FERC 961,050 [1996]).

${ }^{29}$ WPSC owns 50\% of the Petenwell and Castle Rock Hydroelectric Project, which has an approximate total capacity of $35 \mathrm{MW}$, of which WPSC owns 17.5 MW. The 17.5 MW of generation capacity from the Petenwell and Castle Rock Hydroelectric Project is calculated within the total capacity owned (WPSC 2018b).
} 


\begin{tabular}{|c|c|c|c|c|c|}
\hline Licensee & Projects & $\begin{array}{l}\text { Ownerl } \\
\text { Operator }\end{array}$ & Licensee Type & $\begin{array}{l}\text { Total Capacity } \\
\text { Owned (MW) }\end{array}$ & $\begin{array}{l}\text { Asset } \\
\text { Location }\end{array}$ \\
\hline \multirow{4}{*}{$\begin{array}{l}\text { Domtar } \\
\text { Paper } \\
\text { Company, } \\
\text { LLC. }\end{array}$} & $\begin{array}{l}\text { Rothchild } \\
\text { (P-2212) }\end{array}$ & \multirow[t]{4}{*}{$\begin{array}{l}\text { Owner/ } \\
\text { Operator }\end{array}$} & \multirow[t]{4}{*}{$\begin{array}{l}\text { Manufacturer - } \\
\text { Paper Mill }\end{array}$} & \multirow[t]{4}{*}{14} & \multirow[t]{4}{*}{ Wisconsin } \\
\hline & $\begin{array}{l}\text { Centralia } \\
(P-2255)\end{array}$ & & & & \\
\hline & $\begin{array}{l}\text { Port Edwards } \\
\text { (P-2291) }\end{array}$ & & & & \\
\hline & $\begin{array}{l}\text { Nekoosa } \\
(\mathrm{P}-2292)\end{array}$ & & & & \\
\hline \multirow{5}{*}{$\begin{array}{l}\text { Consolidated } \\
\text { Water Power } \\
\text { Co. }\end{array}$} & $\begin{array}{l}\text { DuBay } \\
\text { (P-1953) }\end{array}$ & \multirow[t]{5}{*}{$\begin{array}{l}\text { Owner/ } \\
\text { Operator }\end{array}$} & \multirow[t]{5}{*}{ Public Utility } & \multirow[t]{5}{*}{33} & \multirow[t]{5}{*}{ Wisconsin } \\
\hline & $\begin{array}{l}\text { Stevens } \\
\text { Point } \\
(P-2110)\end{array}$ & & & & \\
\hline & $\begin{array}{l}\text { Whiting } \\
(P-2590)\end{array}$ & & & & \\
\hline & $\begin{array}{l}\text { Biron } \\
(\mathrm{P}-2192)\end{array}$ & & & & \\
\hline & $\begin{array}{l}\text { Wisconsin } \\
\text { Rapids } \\
(\mathrm{P}-2256)\end{array}$ & & & & \\
\hline $\begin{array}{l}\text { Wisconsin } \\
\text { River Power } \\
\text { Co. }{ }^{30}\end{array}$ & $\begin{array}{l}\text { Petenwell } \\
\text { and Castle } \\
\text { Rock } \\
(\mathrm{P}-1984)\end{array}$ & Operator & Public Utility & Unknown & Wisconsin \\
\hline $\begin{array}{l}\text { Wisconsin } \\
\text { Power \& } \\
\text { Light Co. }{ }^{31}\end{array}$ & $\begin{array}{l}\text { Prairie Du } \\
\text { Sac } \\
(\mathrm{P}-11162)\end{array}$ & $\begin{array}{l}\text { Owner/ } \\
\text { Operator }\end{array}$ & Public Utility & 3732 & Wisconsin \\
\hline
\end{tabular}

\footnotetext{
${ }^{30}$ Wisconsin River Power Co. is 50\% owned by WPSC and 50\% owned by Wisconsin Power and Light Company (WPL). The generating capacity of the Petenwell and Castle Rock Project is split evenly between WPSC and WPL. ${ }^{31} \mathrm{WPL}$ is a subsidiary of Alliant Energy Co. Alliant Energy is a public utility holding company headquartered in Madison, Wisconsin.

${ }^{32}$ WPL owns $50 \%$ of the Petenwell and Castle Rock Hydroelectric Project, which has a total capacity of 35 MW, of which WPL owns 17.5 MW. The 17.5 MW of generation capacity from the Petenwell and Castle Rock Hydroelectric Project is calculated within the total capacity owned (WRPC 2018).
} 


\subsubsection{Advantages}

Potential advantages associated with Wisconsin's basin-wide approach to relicensing include:

- Extended license term for all 20 projects

- Initiated by the licensees

- Segmented sub-basin approach groups projects within the same geographic area that have similar vegetation, land cover, hydrology, and resource management concerns

- Minimized resource strain by staggering license expiration dates by sub-basin

- Comprehensive and ecologically sound environmental analysis.

(WPSC 2018; WRPC 2018; Cheryl Laatsch, Wisconsin Department of Natural Resources, telephone conference, August 7, 2018)

\subsubsection{Challenges}

Potential challenges associated with Wisconsin's basin-wide approach to relicensing include:

- Pioneering a comprehensive approach to relicensing - it has never been done before

- Federal and state agency support

- State agency resource constraints

- Licensee resistance to formal settlement agreement

- Licensees have diverse interests and backgrounds

- Licensees have differing levels of resources available

- Some projects have existing settlement agreements, others do not

- Diverse hydropower project purposes.

(Cheryl Laatsch, Wisconsin Department of Natural Resources, telephone conference, August 7, 2018)

\subsubsection{General Advantages and Challenges of Comprehensive Basin-wide Approaches to Relicensing}

Potential advantages associated with basin-wide approaches to relicensing include:

- Extended license terms for projects

- Comprehensive and ecologically sound environmental analysis

- Ability to collaborate and coordinate multiple demands on projects (e.g., whitewater releases)

- Ability to address complex resource balancing issues into a single process

- Information sharing between licensees

- Increased relicensing process efficiencies (e.g., conducting environmental studies for multiple projects at the same time, consolidated consultation processes for multiple project)

- Increased economies of scale

- Upfront communication and coordination with stakeholders to eliminate surprises later in the relicensing process

- Settlement agreement among licensees and stakeholders

- Offsets from external funding sources (e.g., grants) 
- Opportunity to create holistic river basin management plans to reduce risk and increase resiliency

- Reduced workloads for FERC and federal and state resource agencies

- Reduced workloads for tribes and other stakeholders

- Reduced costs in conducting studies, preparing documents and filings, and consultationby pooling resources and spreading costs among licensees

(WPSC 2018; WRPC 2018; Cheryl Laatsch, Wisconsin Department of Natural Resources, telephone conference, August 7, 2018; Jessica Hart, New York State Department of Environmental Conservation Region 6, and John Wiley, U.S. Fish and Wildlife Service, telephone conference, August 7, 2018; Sayad Moudachirou, Ampersand Energy Partners, LLC, telephone conference, August 6, 2018; David Fox, Cube Hydro Partners, LLC, telephone conference, August 6, 2018).

Potential challenges associated with basin-wide approach to relicensing include:

- Pioneering a comprehensive approach to relicensing - it has never been done before

- Accelerated licensed terms for some projects

- Coordination and collaboration among a large stakeholder group

- Licensees may have diverse interests and backgrounds

- Licensees may have differing levels of resources available

- Studies for projects may extend beyond FERC license boundaries

- May require a single consultant to prepare documents/organize studies

- Difficult to decide on a fair way to allocate costs among licensees

- Depends on willingness to collaborate and agreements prior to filing NOI and PAD or new license applications

- Additional coordination and collaboration required could increase the relicensing timeline for an individual project

- Conflict in the decision-making process (e.g., timeline, schedule, consultant to use)

- Conflict when negotiating the terms and conditions of the license - a term or a condition for one project may be at the detriment of another project

- Equity of the relicensing process - larger licensees dictating the relicensing process for smaller licensees, smaller licensees utilizing the resources of the larger licensees

(Jessica Hart, New York State Department of Environmental Conservation Region 6, and John Wiley, U.S. Fish and Wildlife Service, telephone conference, August 7, 2018; Sayad Moudachirou, Ampersand Energy Partners, LLC, telephone conference, August 6, 2018; Steven Murphy, Brookfield Renewable Energy Partners LLC, telephone conference, August 16, 2018; David Fox, Cube Hydro Partners, LLC, telephone conference, August 6, 2018; Cheryl Laatsch, Wisconsin Department of Natural Resources, telephone conference, August 7, 2018).

\subsection{Section 401 Water Quality Certification Coordination}

Hydropower stakeholders are starting to apply basin-wide approaches to individual aspects of the relicensing process, such as obtaining a Section 401 water quality certification from a state resource agency. For instance, California and Maine have implemented a basin-wide approach for review and issuance of a Section 401 water quality certification for multiple hydropower 
projects going through relicense. Both California and Maine ${ }^{33}$ have or are in the process of issuing a single 401 water quality certification for multiple hydropower projects within the same river basin.

Issuing a single certification for multiple hydropower projects is rare - the California and Maine examples provided are the only two instances identified as part of this report's analysis. While in California and Maine the primary reason for consolidating review and issuance largely stems from the interconnected nature of the projects, other applications and advantages can be surmised.

A basin-wide approach to review and issuance of water quality certifications for multiple projects at the same time could allow for a more comprehensive study and analysis of the projects' cumulative impacts on water quality and other environmental attributes, which go beyond the FERC project boundary. A basin-wide approach could also lead to regulatory efficiencies and cost savings, especially given state agency resource restraints and the number of hydropower projects coming up for relicense that are within a shared watershed or river basin. However, the complexities associated with trying to issue a single certification for multiple projects at the same time could outweigh the potential advantages.

\subsubsection{California Big Creek Basin-Wide Pilot}

In August 2018, the California State Water Resources Control Board (SWRCB) issued a draft Section 401 water quality certification for six separate FERC-licensed hydropower projects within the upper San Joaquin River watershed ${ }^{34}$ (SWRCB 2018b). The six hydropower projects are owned and operated by a single licensee, SCE, and are collectively known as the Big Creek Hydropower Projects (Big Creek Projects). Given the demand for certification and the number of FERC-licensed hydropower projects due to expire in the coming years that are within a shared basin, the Big Creek pilot could serve as a model for future projects.

\footnotetext{
${ }^{33}$ In Maine, the MDEP may issue a single Section 401 water quality certification for the relicense of multiple hydropower projects within a river basin at the request of the licensee if the projects exist continuously on a stretch of river (Kathy Howatt, Maine Department of Environmental Protection, email, August 03, 2018). In order to address the interrelated nature of the projects, MDEP in 2003 issued a single certification for five individually FERC-licensed projects_-Saccarappa (P-2897), Mallison Falls (P-2932), Little Falls (P-2941), Gambo (P-2931), and Dundee (P-2942) (Kathy Howatt, Maine Department of Environmental Protection, email, August 03, 2018 ; S.D. Warren Company, 105 FERC $\uparrow$ 61,013 [2003]).

34 The San Joaquin River watershed is 15,600 square miles and flows 100 miles west from the Sierra Nevada Mountains and then flows north 260 miles where it joins the Sacramento River (EPA 2018b). The principal tributaries to the San Joaquin River watershed are the Cosumnes, Mokelumne, Calaveras, Stanislaus, Tuolumne, Merced, Chowchilla, and Fresno Rivers (EPA 2018b).
} 


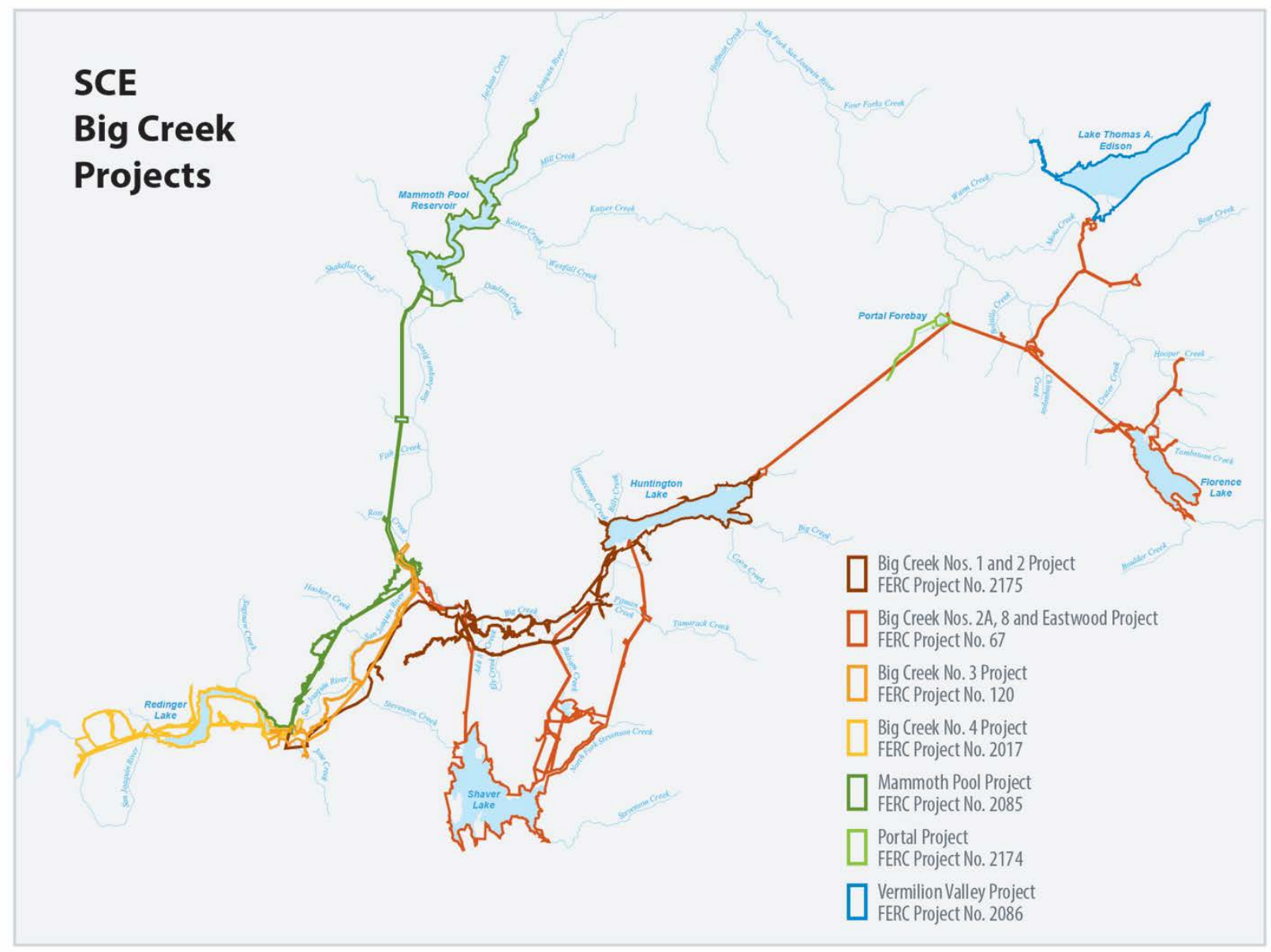

Figure 11. Big Creek case study: map of hydropower projects

\subsubsection{Hydropower Relicensing in California}

There are 74 hydropower projects in California with a total combined generating capacity of approximately 4,387 MW that have FERC licenses due to expire from 2018-2037 (FERC 2017a). Of those projects, approximately 36 have been identified as being among 13 watersheds or river basins (FERC 2017a; ONRL 2018). Of the 74 hydropower projects due to expire, 56 are expected to file an application for a new license with FERC from 2019-2032 (FERC 2017a). Typically, the licensee files for a Section 401 water quality certification with the state around the same time as filing an application for a new license with FERC.

In 2017 California issued 1,221 Section 401 water quality certifications (Jeff Wetzel, California State Water Resources Board, correspondence, September 19, 2018). ${ }^{35}$ As of September 2018, there were 995 projects under review for certification (Jeff Wetzel, California State Water Resources Board, correspondence, September 19, 2018). Of those projects 36 are FERC-licensed hydropower projects Jeff Wetzel, California State Water Resources Board, correspondence, September 19, 2018).

\footnotetext{
${ }^{35}$ Water quality certification total includes those for hydropower projects required by Section 401 of the CWA, dredge and fill activities that require USACE approval under Section 401 of the CWA and Sections 9 and 10 of the Rivers and Harbors Act, Section 402 of the CWA and other state requirements.
} 


\subsubsection{Big Creek Hydroelectric System}

The Big Creek Projects are part of the Big Creek Hydroelectric System ${ }^{36}$ (Big Creek System). The Big Creek System is an integrated network of seven individually FERC-licensed hydropower projects with a total combined generation capacity of 949.41 MW on the upper San Joaquin River watershed in central California (SWRCB 2018a). SCE coordinates all project operations to meet multiple purposes, including the demand for power, to maximize the value of power produced from available water supply and to fulfill downstream water rights and contractual obligations (SWRCB 2018b). One of the seven Big Creek Projects-Big Creek No. 4 (P-2017) - is not part of the basin-wide certification effort. ${ }^{37}$ Table 9 identifies the seven hydropower projects that are part of the Big Creek System, distinguishing which projects are part of the basin-wide certification effort and which project is not.

\footnotetext{
36 The Big Creek Hydroelectric System encompasses 800 square miles and consists of 9 powerhouses containing 23 generating units, 6 major reservoirs, 5 powerhouse forebays, 17 additional diversions, about 54 miles of water conveyance systems, and 2 transmission lines (SCE 2000a; SCE 2000b).

${ }^{37}$ SWRCB issued a water quality certificate for the Big Creek No. 4 Project in June 2003 (SWRCB 2003).
} 
Table 9. Big Creek Case Study: Projects

\begin{tabular}{|c|c|c|c|c|c|}
\hline $\begin{array}{l}\text { Project } \\
\text { Name }\end{array}$ & $\begin{array}{l}\text { Authorized } \\
\text { Generation } \\
\text { Capacity } \\
\text { (MW) }\end{array}$ & $\begin{array}{l}\text { Annual } \\
\text { Production } \\
\text { Generated } \\
\text { (MWh) }\end{array}$ & County & $\begin{array}{l}\text { License } \\
\text { Issuance } \\
\text { Date }\end{array}$ & $\begin{array}{l}\text { License } \\
\text { Expiration } \\
\text { Date }\end{array}$ \\
\hline \multicolumn{6}{|c|}{$\begin{array}{c}\text { Six Big Creek Hydropower Projects covered by basin-wide Section } 401 \text { water quality } \\
\text { certification }\end{array}$} \\
\hline $\begin{array}{l}\text { Big Creek } \\
\text { Nos. 2A, } 8 \text {, } \\
\text { and } \\
\text { Eastwood } \\
(\mathrm{P}-67)\end{array}$ & 373 & 969,566 & Fresno & 03/27/1959 & $02 / 28 / 2009$ \\
\hline $\begin{array}{l}\text { Big Creek No. } \\
3 \\
(P-120)\end{array}$ & 165 & $1,065,476$ & $\begin{array}{l}\text { Fresno } \\
\text { Madera }\end{array}$ & 09/07/1977 & $02 / 28 / 2009$ \\
\hline $\begin{array}{l}\text { Mammoth } \\
\text { Pool } \\
\text { (P-2085) }\end{array}$ & 151 & $1,0008,167$ & $\begin{array}{l}\text { Fresno } \\
\text { Madera }\end{array}$ & $12 / 30 / 1957$ & $11 / 30 / 2007$ \\
\hline $\begin{array}{l}\text { Vermilion } \\
\text { Valley } \\
\text { Reservoir } \\
\text { (P-2086) }\end{array}$ & 0 & 0 & Fresno & 09/01/1953 & $08 / 31 / 2003$ \\
\hline $\begin{array}{l}\text { Portal } \\
\text { (P-2174) }\end{array}$ & 11 & 31,204 & Fresno & 04/19/1955 & $03 / 31 / 2005$ \\
\hline $\begin{array}{l}\text { Big Creek } \\
\text { Nos. } 1 \\
\text { and } 2 \\
(\mathrm{P}-2175)\end{array}$ & 150 & $1,273,849$ & $\begin{array}{l}\text { Fresno } \\
\text { Madera }\end{array}$ & 03/28/2009 & $02 / 28 / 2009$ \\
\hline
\end{tabular}

Big Creek Hydroelectric System project with existing water quality certification

\begin{tabular}{|c|c|c|c|c|c|}
\hline $\begin{array}{l}\text { Big Creek } \\
\text { No. } 4 \\
(\mathrm{P}-2017)\end{array}$ & 99 & 614,764 & $\begin{array}{l}\text { Fresno } \\
\text { Madera }\end{array}$ & $12 / 04 / 2003$ & $12 / 04 / 2039$ \\
\hline
\end{tabular}

Source: SWRCB 2018b

\subsubsection{Implementation History and Process}

Initially SCE sought water quality certification for each of the Big Creek Projects separately because the projects had different FERC license expiration dates. SCE began the relicensing process for the Big Creek Projects in 1997 when it filed an application for a new major license with FERC for the Big Creek No. 4 Project and an application for a water quality certification with SWRCB (SWRCB 2003). The Big Creek No. 4 Project received a water quality certification from SWRCB and a new license from FERC in 2003 (SWRCB 2003).

\footnotetext{
38 The annual generation production is based on SCE's Fiscal 2017 Gross Generation Statement to FERC (SCE 2017).
} 
Consideration: SCE recognized that "the common ownership and location of the seven hydroelectric projects within one watershed provide[d] a unique opportunity to address complex resource balancing issues within a single process" (SCE 2000a).

As early as 1999, SCE determined that although the Big Creek Projects were being relicensed independently, due to their license expiration dates, they planned to discuss all licenses as part of a basin-wide planning process (SCE 1999). SCE committed to analyzing all seven Big Creek Projects during the relicense of Big Creek Nos. 1 \& 2 (license expiration 2009); Big Creek Nos. 2A, 8, \& Eastwood (license expiration 2009); Big Creek No. 3 (license expiration 2009); and Mammoth Pool (license expiration 2007) (SCE 1999; SCE 2000a; SCE 2000b). SCE sought to relicense these four projects through the ALP, which would include developing a basin-wide plan to identify and address issues related to the entire Big Creek System (SCE 1999; SCE 2000a; SCE 2000b). SCE did not seek to align the FERC license expiration dates of the Big Creek Projects in order coordinate the relicensing timelines of the projects and, thereby, Section 401 water quality certification review.

As a result, the majority of the Big Creek Projects had different state and federal filing date deadlines. While SCE initiated a multi-year collaborative process for the relicense of the four ALP projects, the Vermilion Valley Project (license expiration in 2003) was the next Big Creek Project with a FERC license to expire. To meet the filing deadline, SCE applied for a new license with FERC in August 2001. SCE filed an application with SWRCB requesting a water quality certificate or waiver for the Vermilion Valley Project at the same time as filing an application for a new license with FERC (SWRCB 2001).

Consideration: "[W]hile the timing of the license expiration for the Vermilion Valley Project preclude[d] its inclusion into the ALP process, [SWRCB] expect[ed] that aspects of this project would be studied in conjunction with the other relicensing studies conducted in the basin" (SWRCB 2001).

The 2001 water quality certification application initiated a 1-year time period for SWRCB to act on the application for certification for the Vermilion Valley Project. It was then determined that due to the integrated nature of the projects and the pending basin-wide analysis that SWRCB would use the environmental document prepared for the ALP relicensing efforts to inform the water quality certification for all six projects (SWRCB 2001; SWRCB 2006). Since 2001, SCE has annually withdrawn its application for certification for the Vermilion Valley Project and filed a new application with SWRCB. SCE initiated the same certification withdrawal and resubmission process for the Portal Project starting in 2003 and the four ALP projects starting in 2008 (SCE 2015; SCE 2008b).

In 2008, SCE requested that SWRCB consider the Vermilion Project and the Portal Project certification along with the other four projects-Mammoth Pool; Big Creek Nos. 1 \& 2; Big Creek No. 3; and Big Creek Nos. 2A, 8, \& Eastwood - as part of an overall water quality certification (SCE 2008a). In 2009, FERC staff issued the final EIS for the four ALP projects (SCE 2015). Most recently, SCE filed an application for certification of all six projects with the SWRCB on November 20, 2017. 


\section{Coordinated Review}

Utilizing the final EIS and the basin-wide studies, SWRCB staff reviewed all six projects to ensure they complied with the state water quality control plans for the basin (SWRCB 2018b). The water quality control plans (basin plans) for the basin designate the beneficial uses of waters to be protected, along with the water quality objectives necessary to protect those uses (SWRCB 2018). California's basin plans provide a list of water quality objectives that set the limits or levels of water quality constituents and characteristics that are established by the state to protect the beneficial uses identified for the waterbody (SWRCB 2018b). The river basin plan for the Central Valley Region lists municipal and domestic supply, irrigation, stock watering, power, warm and cold freshwater habitat, contract and non-contact recreation, canoeing and rafting, and wildlife habitat as beneficial uses of the San Joaquin River and its sources (SWRCB 2018b).

SCE identified water quality impacts that could be caused by controllable factors from the hydropower projects in order to meet the objectives of the basin plan (SWRCB 2001). SWRCB staff also had to ensure that certification would comply with the California Environmental Quality Act (CEQA). Under CEQA, staff can analyze the project for its incremental effects over existing baseline conditions (SWRCB 2018d).

SWRCB issued a draft Section 401 water quality certification for the six FERC-licensed hydropower projects in August 2018. Many of the resource monitoring and management conditions included in the Big Creek ALP Settlement Agreement filed with FERC in 2007 served as the basis for conditions of the certification (SWRCB 2018b).

\subsubsection{Advantages}

Potential advantages associated with California's basin-wide approach for issuing Section 401 water quality certifications include:

- Consolidated consultation and application process

- Increased certification process efficiencies

- Comprehensive analysis of the cumulative impacts of all the projects on water quality

- Consistency in administration of a single water quality certification

- Coordination and consistency of prescribed conditions from one project to another.

(SCE 2015; Ann Marie Ore, California Water Resources Control Board, telephone conference, August 2, 2018)

\subsubsection{Challenges}

Potential challenges associated with California's basin-wide approach for issuing Section 401 water quality certifications include:

- FERC license expiration dates were not aligned so that filings and review for all projects were on the same timeline

- Increased certification issuance timeline for an individual project

- Increased timelines can lead to a greater likelihood for: studies to become outdated, evolving science, stale agreements, and changing stakeholder representatives.

(SCE 2015; Ann Marie Ore, California Water Resources Control Board, telephone conference, August 2, 2018) 


\subsection{Projects Within a River Basin that Cross Multiple Jurisdictions}

Hydropower projects within a river basin that flows through multiple state jurisdictions may need to comply with the statutory and regulatory requirements in those states. During the relicensing process, the most common instance of multi-jurisdictional authority occurs when two states have a role in ensuring the project complies with the state's water quality standards and issuance of a Section 401 water quality certification or waiver.

For example, three separate FERC-licensed hydropower projects owned and operated by TransCanada Hydro Northeast, LLC - Bellows Falls (P-1855), Wilder (P-1892), and Vernon (P1904) - are concurrently going through the relicensing process (FERC 2018b). These projects are located on the Connecticut River in Windham County, Vermont, and Cheshire County, New Hampshire (Great River Hydro 2017). Due to the projects' locations, TransCanada must comply with the statutory and regulatory requirements of both Vermont and New Hampshire.

Specifically, TransCanada must obtain a Section 401 water quality certification or waiver from the New Hampshire Department of Environmental Services (NH DES) and the Vermont Department of Environmental Conservation (VT DEC) (Great River Hydro 2017). VT DEC and NH DES have been working on the relicensing efforts of these projects since 2012 (Jeff Crocker, Vermont Department of Environmental Conservation, email, July 10, 2018). Although TransCanada has not yet applied for certification for the projects, VT DEC and NH DES have already discussed how they plan to work together and address any potential conflicts with regard to the states' water quality standards (Jeff Crocker, Vermont Department of Environmental Conservation, email, July 10, 2018).

Similarly, the Maine Department of Environmental Protection (MDEP) and NH DES are currently working together to certify the Lower Great Falls Project (P-4451) (Kathy Howatt, Maine Department of Environmental Protection, email, June 27, 2018). The project is located on the Salmon Falls River in Strafford County, New Hampshire, and York County, Maine. Due to the project's location, Somersworth Hydro Company, Inc. (licensee) must obtain a certification or waiver from both Maine and New Hampshire (Somersworth Hydro 2016). MDEP and NE DES are working to coordinate water quality studies and sampling efforts for the relicense of the Lower Great Falls Project as discharge occurs in both states during some spill conditions (Kathy Howatt, Maine Department of Environmental Protection, email, June 27, 2018; email, August 03,2018 ). To that end, each state agency shared their water quality standards and sampling protocol for hydropower studies and have coordinated study plans (Kathy Howatt, Maine Department of Environmental Protection, email, August 03, 2018).

Typically, different water quality standards or classifications of waters between two states with authority to issue water quality certifications do not lead to delay in the relicensing process. States are usually able to work out their differences and issue certifications that do not conflict with one another. However, it is possible that two states with authority could issue draft water quality certifications with conflicting conditions, as found in the Hells Canyon case study.

\subsubsection{Hells Canyon Hydroelectric Complex}

The Hells Canyon Hydroelectric Complex (Hells Canyon Complex) (P-971) is located on a 38mile section of the Snake River that runs south to north and forms the border between Oregon and Idaho. The length of the project extends just over 95 river miles. The project consists of 
three developments with a combined generating capacity of 1,167 MW: Hells Canyon (391.5 MW), Oxbow (190 MW), and Brownlee (585.4 MW). The project generates between 7 million MWh and 9 million MWh of electricity annually, providing power to over 758,485 customers in Idaho Power Company's (Idaho Power) southern Idaho and eastern Oregon service territory (IDACORP 2017; Idaho Power 2003).

The former Federal Power Commission (FPC) issued an original 50-year license for the Hells Canyon Complex in 1955 (Idaho Power Co., 14 FPC $\mid 35$ [1955]). The project's license expired in July 2005, and since then, the project has operated under an annual license. The relicense application remains pending.

\subsubsection{Relicense}

Idaho Power, the project's licensee, filed a timely NOI to relicense the Hells Canyon Complex with FERC in July 2000 and a subsequent application for a new license in July 2003. FERC staff issued a draft EIS in July 2006 and a final EIS in August 2007 (FERC 2006; FERC 2007). Beginning in July 2003, Idaho Power also filed applications for water quality certifications under Section 401 of the CWA with the Idaho Department of Environmental Quality (IDEQ) and the Oregon Department of Environmental Quality (ODEQ). Since 2003, to avoid possible denial of certification, Idaho Power has withdrawn and refiled its water quality certification applications each year-establishing a new 1-year deadline (Order Dismissing Petition for Declaratory Order, 158 FERC \ 61,048 [2017]).

Consideration: Licensees commonly withdraw water quality certification applications and resubmit them to give deference to state resource agencies that only have 1 year to complete often complex water quality studies and consultations (Barry Burnell and Loren Moore, Idaho Department of Environmental Quality, telephone conference, August 10, 2018).

Because relicensing the project may affect several threatened and endangered fish species, FERC must consult with NOAA Fisheries and the USFWS under Section 7(a)(2) of the ESA (16 U.S.C. $\S 1536$ [a][2] [2016]). Both NOAA Fisheries and USFWS have declined to begin ESA consultation until after the states have issued or waived water quality certification (Order Dismissing Petition for Declaratory Order, 158 FERC \ 61,048 [2017]). Idaho Power states the "primary reason for the relicensing delay has been the process of obtaining water quality certification from both Oregon and Idaho" (Order Dismissing Petition for Declaratory Order, 158 FERC ๆ 61,048 [2017]).

Project works ${ }^{39}$ of the Hells Canyon are located in both Idaho and Oregon, and the project discharges into the navigable waters of both states for purposes of Section 401 of the CWA (33

\footnotetext{
${ }^{39}$ Under Section 4(e) of the FPA, FERC licenses "project works." Pursuant to Section 3(12) of the FPA, such "works" are defined as the physical structures of the "project" (16 U.S.C. § 796[12]). A project is a "complete unit of improvement or development" consisting of "a power house, all dams and appurtenant works and structures (including navigation structures)... and all storage, diverting or forebay reservoirs... all miscellaneous structures used and useful in connection with said unit or any part thereof, and all water rights, rights-of-way, ditches, dams, reservoirs, lands, or interest in lands the use and occupancy of which are necessary or appropriate in the maintenance and operation of such unit..." (16 U.S.C. $\S \S 796[11]-[12], 797[\mathrm{e}]$ ).
} 
U.S.C. $\S 1341$ [2016]). As a result, both states have authority to issue a water quality certification for the project under Section 401 of the CWA.

As of June 14, 2018, Idaho Power has withdrawn and resubmitted the project's water quality certification application with IDEQ and ODEQ 15 times since July 2003. Of those 15 applications, only the 2016 application was complete enough for consideration by the States of Idaho and Oregon. (Barry Burnell, Idaho Department of Environmental Quality, telephone conference, August 10, 2018). The main reasons for delay prior to Idaho Power's 2016 water quality certification application submission stem from complex water quality concerns regarding water temperature, dissolved oxygen, nutrients, mercury, and total dissolved gas levels (IDEQ 2016; DEQs 2004). In 2004, Idaho and Oregon worked together to issue a total maximum daily load (TMDL) for the Hells Canyon Complex pursuant to Section 303(d) of the CWA (DEQs 2004). For waters identified as not meeting water quality standards and listed as impaired, states and tribes must develop a TMDL for the pollutants causing impairment, set at a level to achieve water quality standards (33 U.S.C. $\S 1314[\mathrm{a}][2][\mathrm{D}]$ ). In the joint issuance of the TMDL, both states agreed that the Hells Canyon Complex contributed to violations of water quality standards related to nutrients and dissolved oxygen, salmonid spawning temperature, and total gas (DEQs 2004). The 2004 TMDL provided specific allocations for Idaho Power and other sources to attain compliance with both Idaho's and Oregon's water quality standards (DEQs 2004; IDEQ 2006).

Consideration: Idaho, Oregon, and Idaho Power have adopted the principle that when faced with differing water quality standards, the more stringent standards control the certification process for the Hells Canyon Complex (Mark Cecchini-Beaver, Deputy Attorney General, telephone conference, August 10, 2018).

In 2016, after more than a decade of studies, meetings, and negotiations, both IDEQ and ODEQ issued separate draft water quality certifications. The terms and conditions of the water quality certifications were compatible except for issues regarding fish passage and reintroduction of anadromous fish in tributaries above Hells Canyon Dam. In short, Oregon supports fish passage and reintroduction, and Idaho statutes prohibit these measures (Order Dismissing Petition for Declaratory Order, 158 FERC $\uparrow$ 61,048 [2017]).

Idaho Power and the states are continuing to work together to come to an agreement on these measures. Most recently, on June 14, 2018, Idaho Power resubmitted a water quality certification application for the Hells Canyon Complex to both IDEQ and ODEQ (Idaho 2018). Until the states issue or deny the water quality certification and FERC completes an ESA consultation with NOAA Fisheries and USFWS FERC cannot act on the relicense application, and the relicense of the Hells Canyon Dam will remain pending (Order Dismissing Petition for Declaratory Order, 158 FERC $\uparrow$ 61,048 [2017]). 


\section{Proposed Federal Legislation}

The previous Congress introduced legislation that recognized the value of utilizing basin-wide approaches for the FERC hydropower authorization process. H.R. 3043 (Hydropower Policy Modernization Act of 2017) would require FERC to establish a program to develop comprehensive plans, at the request of a project applicant, on a regional or basin-wide scale where there is more than one project (Uria-Martinez et al. 2018). Upon such request, FERC may also conduct or commission regional or basin-wide environmental studies, with the participation of at least two applicants (H.R. 3043, $115^{\text {th }}$ Congress 2017). 


\section{Conclusion}

The basin-wide initiatives illustrated in this report operate under existing law and can serve as models for hydropower projects that are expected to go through the relicensing process in the near future. With more than half the FERC-licensed hydropower fleet due to expire in the coming years, these basin-wide approaches could serve an important role to ensure that the hydroelectric capacity from these projects continue to support the U.S. electric grid.

These basin-wide approaches could also act as a spring board for new innovative ideas. The basin-wide study analysis that the New York pilot proposes could be utilized to inform Section 10(j) resource agency recommendations, Section 10(a) comprehensive plan considerations, and Section 18 fish prescriptions pursuant to the FPA for multiple projects within a basin (Jessica Hart, New York State Department of Environmental Conservation Region 6, and Jonathan Binder, New York State Department of Environmental Conservation, telephone conference, July 9, 2018; Jessica Hart, New York State Department of Environmental Conservation Region 6, email, August 1, 2018). These basin-wide studies could also inform environmental review under NEPA; Section 401 water quality certification for the CWA, as illustrated in California and Maine; and Section 7 species review under the ESA (Jessica Hart, New York State Department of Environmental Conservation Region 6, and Jonathan Binder, New York State Department of Environmental Conservation, telephone conference, July 9, 2018; Jessica Hart, New York State Department of Environmental Conservation Region 6, email, August 1, 2018). In addition, basinwide approaches could potentially be utilized for Section 106 cultural and historic resource review pursuant to the NHPA because the majority of historic settlements were built on or near a waterway (James Duggan, Laura Trieschmann, and Yvonne Basque, Vermont Agency of Commerce and Community Development, telephone conference July 16, 2018). To that end, finding regulatory efficiencies and cost savings within the relicensing process will help ensure hydropower's contributions toward meeting the nation's energy needs, maintaining national infrastructure, and improving national security (DOE 2016). 


\section{References}

Ampersand Energy (Ampersand Energy Partners, LLC). 2018. "Hydropower." Last accessed August 17, 2018. http://ampersandenergy.com/portfolio/.

Bauer, S., Jennifer Olsen, Adam Cockrill, Michael van Hattern, Linda Miller, Margaret Tauzer, and Gordon Leppig. 2015. "Impacts of Surface Water Cultivation on Aquatic Habitat in Four Northwestern California Watersheds." PLOS ONE 10 (9) (March 18, 2015).

Brookfield Renewable (Brookfield Renewable Partners L.P.) 2017. 2017 Annual Report. Bermuda: Brookfield Renewable. https://bep.brookfield.com/ /media/Files/B/Brookfield-BEPIR/Annual\%20Reports/2017-annual-report.pdf.

Carthage (Carthage Specialty Paperboard). 2016. "Carthage Paper Makers Mill Project (P10887) License Extension Request to the Federal Energy Regulatory Commission." August 4, 2016.

Coggins, G., and Robert L. Glicksman. 2018. "Background-Electric Consumers Protection Act.” Amendments, 4 Pub. Nat. Resources L. § 37:23 (2nd ed.) (June 2018).

Colorado Legislative Council. 2014. "State and Local Impact Note - Repeal of Statutory Quality Fee Schedules." February 6, 2014. http://statebillinfo.com/bills/fiscal/14/SB134_00.pdf.

Copeland, C. 2015. "Clean Water Act Section 401: Background and Issues." Congressional Research Service Report. July 2, 2015. https://fas.org/sgp/crs/misc/97-488.pdf.

Cube Hydro. 2018. “Cube Hydro Managed Assets.” Last accessed June 13, 2018. https://www.cubehydropartners.com/portfolio/.

Cumming, Catherine. 2015. "The Hydropower Regulatory Efficiency Act: Not Giving a Dam for Negative Externalities and Stakeholder Oversight." Minnesota Journal of Law, Science \& Technology 16 (2): 917-56.

DEQs (Idaho Department of Environmental Quality and Oregon Department of Environmental Quality). 2004. Snake River - Hells Canyon: Total Maximum Daily Load (TMDL). http://www. deq.idaho.gov/media/454498-snake river hells canyon entire.pdf.

DOE (U.S. Department of Energy). 2016. Hydropower Vision Study. Washington, D.C.: DOE. https://www.energy.gov/sites/prod/files/2018/02/f49/Hydropower-Vision-021518.pdf.

Domtar (Domtar Wisconsin Corporation). 2018. "Domtar Non-Capacity Amendment Application Proposal to Wisconsin Department of Natural Resources for Centralia, Port Edwards and Nekoosa Hydroelectric Projects.” August 10, 2018.

EPA (U.S. Environmental Protection Agency). 2018a. "EnviroAtlas Fact Sheet - Hydrologic Unit Codes: HUC 4, HUC 8, and HUC 12." https://enviroatlas.epa.gov/enviroatlas/DataFact Sheets/pdf/Supplemental/HUC.pdf. 
- 2018b. "San Francisco Bay Delta - About the Watershed: The San Joaquin River Watershed." Last accessed September 5, 2018. https://www.epa.gov/sfbay-delta/aboutwatershed.

- 2010. Clean Water Act Section 401 Water Quality Certification: A Water Quality Protection Tool for States and Tribes. http://dec.vermont.gov/sites/dec/files/wsm/boss/docs/ 401_Handbook_2010_Interim.pdf.

FERC (Federal Energy Regulatory Commission). 1994. "Policy Statement on Use of Reserved Authority in Hydropower Licenses to Ameliorate Cumulative Impacts." Docket No. RM93-25000. December 28, 1994. Washington, D.C.: FERC.

_ 2001. "Staff Report to Congress, Report on Hydroelectric Licensing Policies, Procedures, and Regulations - Comprehensive Review and Recommendations Pursuant to Section 603 of the Energy Act of 2000." Washington, D.C.: Federal Energy Regulatory Commission. https://www.ferc.gov/legal/maj-ord-reg/land-docs/ortc final.pdf.

2004. "Handbook for Hydroelectric Project Licensing and 5 MW Exemptions from Licensing." Washington, D.C.: Federal Energy Regulatory Commission. https:/www.ferc.gov/ industries/hydropower/gen-info/handbooks/licensing_handbook.pdf.

- 2006. Draft Environmental Impact Statement (DEIS) Evaluates Relicensing of the 1,167 MW Hells Canyon Hydroelectric Project (P-1971) in Idaho and Oregon. July 28, 2006. https://www.ferc. gov/industries/hydropower/enviro/eis/2006/07-28-06.asp.

- 2007. Final Environmental Impact Statement (FEIS) Evaluates Relicensing of the 1,167 MW Hells Canyon Hydroelectric Project (P-1971) in Idaho and Oregon. August 31, 2007. Washington, D.C.: FERC.

- 2014. "Federal Energy Regulatory Commission Letter to California Hydropower Licensees Regarding California Drought.” February 6, 2014. Washington, D.C.: FERC. https:/www.waterboards.ca.gov/waterrights/water_issues /programs/water_quality_cert/docs/ferc_drought_final_tr_020614.pdf.

- 2015. "Division of Hydropower Administration and Compliance, Compliance Handbook.” Washington, D.C.: Federal Energy Regulatory Commission. https://www.ferc.gov/industries/ hydropower/gen-info/handbooks/compliance_handbook.pdf.

—. 2017a. "Expected Relicense Projects FY 2017 - FY 2032.” Updated July 26, 2017. https://www.ferc.gov/industries/hydropower/gen-info/licensing.asp.

- 2017b. "Policy Statement on Establishing License Terms for Hydroelectric Projects." Docket No. PL17-3-000. October 19, 2017. https://www.ferc.gov/whats-new/comm$\underline{\text { meet } / 2017 / 101917 / \mathrm{H}-1 . p d f}$. 
—. 2018a. “Complete List of Active Licenses.” Excel Sheet. Updated December 12, 2018. https://www.ferc.gov/industries/hydropower/gen-info/licensing.asp.

-. 2018b. "Pending FERC Hydropower Licenses, Relicenses, and Exemptions." Excel Sheet. Updated December 12, 2018. https://www.ferc.gov/industries/hydropower/geninfo/licensing.asp.

_. 2018c. "Projects Delayed by Water Quality Certifications and Endangered Species Act Consultation." Excel Sheet. Updated December 12, 2018.

https://www.ferc.gov/industries/hydropower/gen-info/licensing.asp.

FWS (U.S. Fish and Wildlife Service). 2010. "Overview of the Federal Power Act and the Hydropower Relicensing Process.” Washington D.C.: U.S. Fish and Wild Life Service. https://www.fws.gov/policy/hydrochap2.pdf.

Great River Hydro (Great River Hydro, LLC). 2017. "Bellows Falls Hydroelectric Project (P1855-045) Application for New License.” May 1, 2017.

Hart, Jessica. 2017. "Black River Hydros: A Basin-Wide Approach.” New York: New York State Department of Environmental Conservation Region 6. August 30, 2017.

Hawaii State Department of Health. 2015. "Response to Comments and Final Determinations on Public Notice Section 401 Water Quality Certification for Certain 2012 Department of Army Nationwide Permits." August 14, 2015. http://health.hawaii.gov/cwb/files/2013/04/08011CEC.15 WQC0804-Response-toComments.pdf.

Hydro Ottawa Holding Inc. 2017. HydroOttawa Annual Report 2017. https://static.hydroottawa.com/documents/publications/annual-report/2017-Annual-ReportEN.pdf.

IDACORP, Inc. 2017. Idaho Power Company 2016 Annual Report. February 23, 2017. http://www.idacorpinc.com/ c/media/Files/I/IDACorp/investor-docs/annual-reports/ar2016.pdf.

Idaho Power (Idaho Power Company). 1997. Formal consultation package for relicensing, Hells Canyon Project (FERC No. 1971). Boise, ID: Idaho Power Company.

—. 2003. "New License Application for the Hells Canyon Project (FERC No. 1971)." https://docs.idahopower.com/pdfs/relicensing/hellscanyon/hellspdfs/hc licenseapp.pdf.

- 2018. "Section 401 Water-Quality Certification Application for Hells Canyon Complex (FERC No. 1971).” June 2018.

https://docs.idahopower.com/pdfs/Relicensing/hellscanyon/hellspdfs /HCC401Application.pdf. 
IDEQ (Idaho Department of Environmental Quality). 2016. Draft Section 401 Water Quality Certification for Hells Canyon Complex FERC Project No. 1971.

https://www.deq.idaho.gov/media/60179448/hells-canyon-complex-ferc-401-certification-draft1216.pdf.

Levine, Aaron, Taylor L. Curtis, and Borna Kazerooni. 2017. Regulatory Approaches for Adding Capacity to Existing Hydropower Facilities. NREL/TP-6A20-70121. Golden, CO: National Renewable Energy Laboratory. https://www.nrel.gov/docs/fy18osti/70121.pdf.

Aaron Levine and Austin Flanagan. Forthcoming. FERC Hydropower Licensing: A Review of the ILP, TLP, and ALP. NREL/TP-6A20-71982. Golden, CO: National Renewable Energy Laboratory.

Lyons Falls Hydropower. 2018. “About Northbrook Lyons Falls.” Last accessed August 25, 2018. http://www.lyonsfallshydro.com/about-north-brook/.

Minnesota Pollution Control Agency. 2018. "Clean Water Act Section 401 Water Quality Certifications." Last accessed September 2, 2018. https://www.pca.state.mn.us/water/cleanwater-act-section-401-water-quality-certifications.

Missouri Department of Natural Resources. 2008. Funding Missouri's Clean Water Effort. https://dnr.mo.gov/env/wpp/cwpf/docs/cwpf-whitepaper.pdf.

NYSDEC (New York State Department of Environmental Conservation). 2004. "Black River Waterbody Inventory/Priority Waterbodies List Water Quality Assessment Information Summary." https://www.dec.ny.gov/docs/water_pdf/pwlblckasmt.pdf.

Oakley, M. 2018. Using Basin Management to Increase Environmental Resiliency and to Mitigate Risk. Presentation at HydroVision International in Charlotte, North Carolina, June 2628, 2018.

Oregon Department of Environmental Quality. 2018. "WQ Permitting Program Overview." Last accessed September 2, 2018. https://www.oregon.gov/deq/wq/wqpermits/Pages/WQ-PermittingProgram-Review.aspx.

Samu, N.M., S.-C. Kao, P.W. O'Connor, M.M. Johnson, R. Uria-Martinez, and R.A. McManamay. 2018. "National Hydropower Plant Dataset, Version 2 (FY18Q3)." Existing Hydropower Assets [series] FY18Q3. National Hydropower Asset Assessment Program. Oak Ridge, TN: Oak Ridge National Laboratory. https://hydrosource.ornl.gov/market-info-anddata/existing-hydropower-assets/existing-hydropower-assets-datasets/national.

Saulsbury, B., S.H. Geerlofs, G.F. Cada, and M.S. Bevelhimer. 2010. Basin-Scale Opportunity Assessment Initiative: Background Literature Review. ORNL/TM-2010/291. Oak Ridge, TN: Oak Ridge National Laboratory. 
SCE (Southern California Edison). 1999. Southern California Edison's Request to the Federal Energy Regulatory Commission to Use the Alternative Licensing Process for the Relicense of Big Creek Hydroelectric System - FERC Project Nos. 067, 120, 2085, and 2175. December 10, 1999.

2000a. Request for Active Participation by the USFWS Energy and Endangered Species Divisions in the Big Creek System Alternative Licensing Process (FERC Nos. 67, 120, 2175, and 2085). December 20, 2000.

_. 2000b. "Initial Information Package for the Big Creek Hydroelectric System, Alternative Licensing Process.” May 2000. https://www.sce.com/nrc/bigcreek/2000_IIP.pdf.

-.2008a. Request for Water Quality Certification for the Relicensing of the Federal Energy Regulatory Commission Projects of Portal (FERC No. 2174) and Vermilion Valley (FERC No. 2086). July 10, 2008.

- 2008b. Application for Clean Water Act Section 401 Water Quality Certification for the Southern California Edison Company's Mammoth Pool (P-2085), Big Creek Nos. 1 \& 2 (P2175), Big Creek No. 3 (P-120), and Big Creek Nos. 2A, 8 \& Eastwood (P-67) Hydroelectric Projects. March 4, 2008.

- 2015. Letter to California State Water Resources Control Board from Southern California Edison in regard to withdrawal and resubmission of an application for Clean Water Act Section 401 Water Quality Certification for the Vermilion Valley (P-2086), Portal (P-2174), Mammoth Pool (P-2085), Big Creek Nos. 1 \& 2 (P-2175), Big Creek No. 3 (P-120), and Big Creek Nos. 2A, 8 \& Eastwood (P-67) Hydroelectric Projects. December 8, 2015.

2017. Fiscal Year 2017 Gross Generation Statement for FERC Project Nos. 67, 120, 298, 344, 372, 382, 1388, 1389, 1394, 1930, 1933, 1934, 2017, 2085, 2174, 2175, 2290. October $30,2017$.

Sensiba, Charles R. 2011. "Hydropower." The Law of Clean Energy Efficiency and Renewables, 479: 484-5.

Somersworth Hydro (Somersworth Hydro Company, Inc.). 2016. "Pre-Application Document Volume 1 of 2: Lower Great Falls Hydroelectric Project (P-4451).” December 2016.

Strong, Clive J. 1991. Statement on behalf of the National Association of Attorneys General, in, U.S. Congress, Senate, Commitee on Environmental and Public Works, Subcommittee on Environmental Protection. Water Pollution Prevention and Control Act of 1991, hearings on S. 1081, 102d Congress, $1^{\text {st }}$ session, Washington, D.C.: GPO. (S. Hrg. 102-335).

SWRCB (California State Water Resources Control Board). 2001. Response to Request for Water Quality Certification, Vermilion Valley Hydroelectric Project, FERC No. 2086, September 28, 2001. 
- 2003. Water Quality Certification for the Southern California Edison Company Big Creek No. 4 Hydroelectric Project. June 13, 2003.

https://www.waterboards.ca.gov/waterrights/water issues /programs/water_quality_cert/docs/bigcreek_fercs/2017bigcreek4.pdf.

- 2006. Response Regarding Withdrawal and Resubmittal of the Request for Water Quality Certification for the Vermillion Valley Hydroelectric Project (FERC 2086). October 31, 2006.

2014. "State Water Resources Control Board Letter to Federal Energy Regulatory Commission Regarding Drought Assistance for California Hydropower Projects. March 11, 2014. https://www. waterboards.ca.gov/waterrights/water_issues/programs/water_quality_cert/docs/abrams_ferc 03 112014.pdf.

- 2018a. "California State Water Resource Control Board - Water Quality Certification Program." Last accessed September 2, 2018. https://www.waterboards.ca.gov/waterrights/water_issues/programs /water_quality_cert/big_creek/.

- 2018b. Draft Water Quality Certification for Federal Permit or License for Six Big Creek Hydroelectric Projects: Big Creek Nos. 2A, 8 and Eastwood Hydroelectric Project, Big Creek No. 3 Hydroelectric Project, Mammoth Pool Hydroelectric Project, Vermilion Valley Hydroelectric Project, Portal Hydroelectric Project, and Big Creek Nos. 1 and 2 Hydroelectric Project. August 13, 2018. https://www.waterboards.ca.gov/waterrights/water_issues/programs/water_quality_cert big_creek/docs/draft_bc_wqc.pdf.

- 2018c. Water Quality Certification Program - Projects. Last accessed September 8, 2018. https://www.waterboards.ca.gov/ waterrights/water issues/programs/water quality cert/ceqa projects.shtml.

https://

2018d. Division of Water Rights, Water Quality Certification Program Overview.

www.waterboards.ca.gov/waterrights/water_issues/programs/water_quality_cert/docs/wqcertpro g_overview.pdf.

Uria-Martinez, Rocio, Megan M. Johnson, and Patrick W. O'Conner. 2015. 2014 Hydropower Market Report. Oak Ridge, TN: Oak Ridge National Laboratory. https://www.energy.gov/sites/ prod/files/2015/05/f22/2014\%20Hydropower\%20Market\%20Report_20150512_rev6.pdf.

—. 2018. U.S. Hydropower Market Report 2017 Update. Oak Ridge, TN: Oak Ridge National Laboratory. https://www.energy.gov/sites/prod/files/2018/04/f51/Hydropower\%20Market\%20Report.pdf.

U.S. Geological Survey, Department of Interior. 1917. Profile Surveys of Rivers in Wisconsin. https://pubs.usgs.gov/wsp/0417/report.pdf. 
WDNR (Wisconsin Department of Natural Resources). 2002. Headwaters State of the Basin Report. https://nnr.wi.gov/topic/watersheds/documents/basins/upwis/headwaters12.pdf.

—. 2018a. "Central Wisconsin River Basin.” Last accessed August 29, 2018. https://nr.wi.gov/topic/watersheds/basins/cwrb/.

_. 2018b. "Lower Wisconsin River Basin.” Last accessed September 1, 2018. https://dnr.wi.gov/topic/watersheds/basins/lowerwis/.

- 2018c. Response Letter to Wisconsin River Power Company in Regard to Request for Comment on the Proposed License Extension of the Petenwell and Castle Rock Hydropower Dams (P-1984). July 19, 2018.

Wiley, J. 2015. “Beaver River and Black River Relicensing Excel Data.” December 2, 2015.

WPSC (Wisconsin Public Service Corporation). 2018. Wisconsin Public Service Non-Capacity Amendment Application Proposal to Wisconsin Department of Natural Resources. April 30, 2018.

"Hydroelectric Power Plant." 2018b. Last accessed September 1, 2018.

https://accel.wisconsinpublicservice.com/company/hydroelectric.aspx.

WRPC (Wisconsin River Power Company). 2018. Wisconsin River Power Company NonCapacity Amendment Application Proposal to Wisconsin Department of Natural Resources. April 30, 2018.

WVIC (Wisconsin Valley Improvement Company). 2018a. "Wisconsin River Facts." Last accessed August 29, 2018. http://www.wvic.com/Content/Wisconsin River.cfm.

_. 2018b. “Wisconsin River Reservoir Operating Plan.” Last accessed August 30, 2018. http://www.wvic.com/Content/Operations_Plan.cfm.

\section{Federal and State Statutes, and Bills}

Clean Water Act of 1972, PL 92-500, 86 Stat. 47 (33 U.S.C. $\S § 1251$ - 1376 [October 18, 1972]).

Coastal Zone Management Act of 1972, PL 92-583, 86 Stat. 1280 (16 U.S.C. $\S \S 141-1464$

[October 27, 1972]).

Electric Consumers Protection Act of 1986, PL 99-495, 100 Stat. 1243 (16 U.S.C. § $791 \mathrm{a}$ [October 16, 1986]).

Endangered Species Act of 1973, PL 93-205, 87 Stat. 884 (16 U.S.C. $\S § 1531$ - 1544 [December $28,1973])$.

Federal Power Act of 1920, PL 66-281, 41 Stat. 1063 (16 U.S.C. §§ 791 - 828c [June 10, 1920]). 
Fish and Wildlife Coordination Act, PL 85-624, 48 Stat. 491 (16 U.S.C. §§ 661-666c [March 10, 1934]).

Hydropower Policy Modernization Act of 2017, H.R. 3043, $115^{\text {th }}$ Congress (2017).

National Environmental Policy Act of 1969, PL 91-190, 89 Stat. 493 (42 U.S.C. $§ \S 4321-4347$ [January 1, 1970]).

National Historic Preservation Act of 1966, PL 102-575, 80 Stat. 915 (16 U.S.C. $\S \S 470$ - 470x6 [October 15, 1966]).

Rivers and Harbors Appropriation Act, PL 90-483, 59 Stat. 10 (33 U.S.C. $\S \S 400-467$ [March 3, 1899]).

Wild and Scenic Rivers Act of 1968, PL 90-542, 128 Stat. 3791 (16 U.S.C. $\S \S 1271-1287$ [October 2, 1968]).

\section{Federal and State Regulations}

18 C.F.R. $\S \S 4.1-50.11$ (1947), Regulations under the Federal Power Act.

18 C.F.R. $\S \S 385.101-385.2202$ (1982), Federal Energy Regulatory Commission Rules of Practice and Procedure.

40 C.F.R. $\S \S 1508.1-1508.28$ (1970), Council on Environmental Quality Rules and Regulations.

OR. AdmIN. R. § 690-051-0290 (2018), Appropriation and Use of Water for Hydroelectric Power and Standards for Hydroelectric Applications, Consolidated Review.

\section{Case Law, Dockets, and Orders}

Abenaki Nation of Mississquoi v. Hughes, 990 F.2d 729 (2d Cir. 1993).

Ampersand Kayuta Lake Hydro, LLC 160 FERC ๆ 62,066 (2017).

Beebee Island Corporation, 77 FERC $\uparrow$ 61,305 (1996).

Brookfield White Pine Hydro LLC, 161 FERC \ 62,083 (2017).

City of Holyoke Gas and Electric Department, 145 FERC \ 62,131 (2013).

Climax Manufacturing Co., 57 FERC \ 62,145 (1991).

Climax Manufacturing Co., 156 FERC \ 62,197 (2016).

Erie Boulevard Hydropower, L.P., 161 FERC $q$ 62,021 (2017).

Georgia-Pacific Corporation, 35 FERC $₫$ 62,229 (1986).

Idaho Power Co., 14 FPC 935 (1955). 
Lawrence R. Taft, 38 FERC \%2,293 (1987).

Long Lake Energy Corporation, 35 FERC \ 62,230 (1986).

Lyonsdale Associates, LLC 160 FERC ๆ 62,181 (2017).

Niagara Mohawk Corporation, 76 FERC $₫$ 61,152 (1996).

Niagara Mohawk Power Corporation, 77 FERC \ 61,306 (1996).

Northern States Power Company, 149 FERC $₫$ 62,090 (2014).

Order Dismissing Petition for Declaratory Order, 158 FERC $\uparrow$ 61,048 (2017).

Public Utility of District No. 1 of Chelan County, Washington FERC 1 61,152 (2009).

Public Utility of District No. 1 of Jefferson County v. Washington Department of Ecology, 511 U.S. 700 (1994).

Sappi Cloquet LLC, 162 FERC $\ 62,087$ (2018).

S.D. Warren Company, 105 FERC $\uparrow 61,013$ (2003).

S.D. Warren Co. v. Maine Board of Environmental Protection, 126 U.S. 1843 (2006).

Seneca Falls Power Co., et al. 118 FERC $\uparrow$ 61,195 Order Denying Rehearing (2007).

Wisconsin Valley Improvement Company, 76 FERC $₫$ 61,050 (1996).

Settlement Agreements and Offers of Settlement

Settlement Agreement for Beaver River Project, FERC No. 2645 (1995).

Settlement Agreement for Black River Project, FERC No. 2569 and Beebee Island Project, FERC No. 2538 (1995). 